\title{
A Review of Winterkill Remediation Techniques for Alberta
}
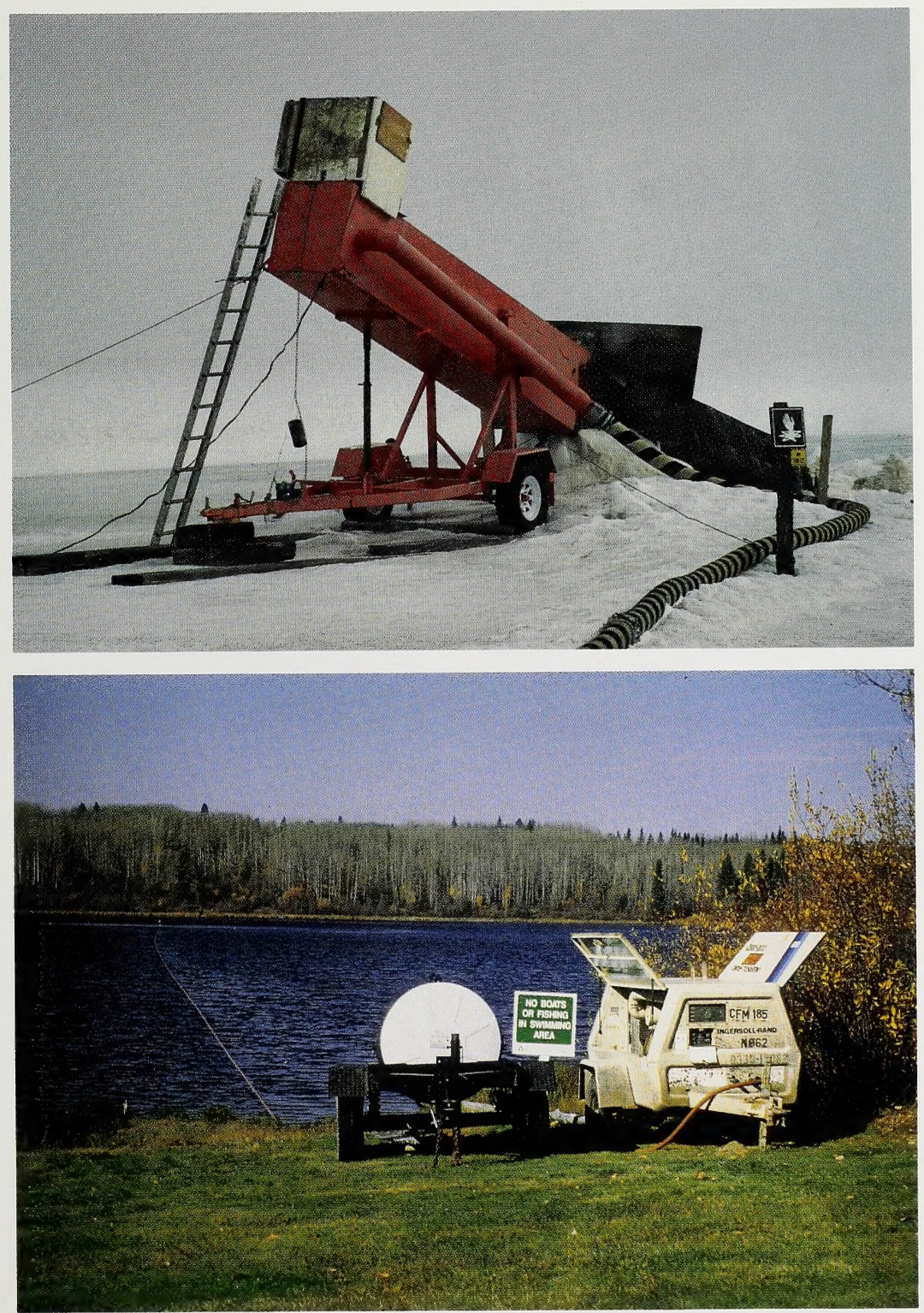

Karl Schwalme, Ph.D.

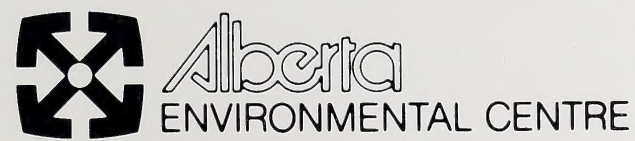


Digitized by the Internet Archive in 2015 
FEB 141995

A REVIEW OF WINTERKILL REMEDIATION TECHNIQUES FOR ALBERTA

by

Karl Schwalme

Research Scientist

Alberta Environmental Centre

January 20, 1995 
This publication may be cited as:

Schwalme, K. 1994. A Review of Winterkill Remediation Techniques for Alberta. Vegreville, AB. AECV94-R7. $84 \mathrm{pp}$.

ISBN \# 0-7732-1657-X. 
LIST OF TABLES

LIST OF FIGURES vi

ACKNOWLEDGMENTS vii

EXECUTIVE SUMMARY viii

INTRODUCTION

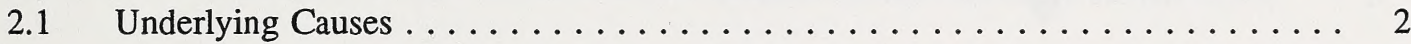

2.2 Oxygen Dynamics of Ice-covered Lakes $\ldots \ldots \ldots \ldots \ldots \ldots \ldots \ldots$

2.3 The Role of Fish Respiration in Winter Oxygen Depletion ............ 9

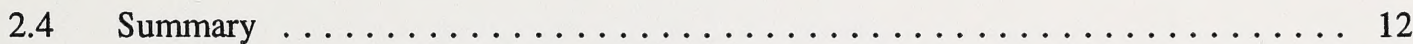

3 WINTER MORTALITY OF FISH $\ldots \ldots \ldots \ldots \ldots \ldots \ldots \ldots \ldots \ldots$

3.1 Modus Operandi $\ldots \ldots \ldots \ldots \ldots \ldots \ldots \ldots \ldots \ldots \ldots \ldots \ldots \ldots \ldots \ldots$

3.2 Complicating Factors $-\mathrm{H}_{2} \mathrm{~S}, \mathrm{NH}_{3}, \mathrm{CO}_{2}, \mathrm{CH}_{4}$, Starvation $\ldots \ldots \ldots \ldots \ldots \ldots$

3.3 Winter Oxygen Requirements of Freshwater Gamefish . . . . . . . . . . . . . 19

3.4 Behavioural Responses of Fish to Oxygen Gradients $\ldots \ldots \ldots \ldots \ldots \ldots \ldots$. . . 27

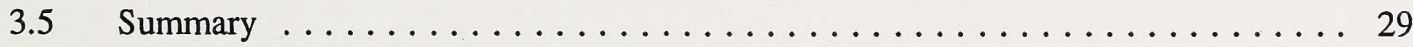

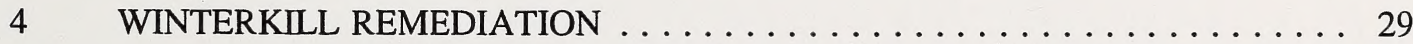

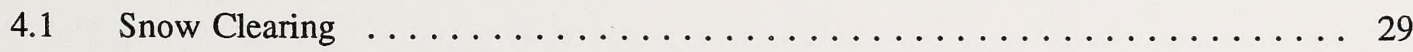

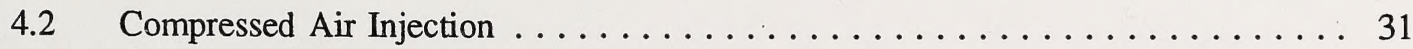

4.3 Mechanical Surface Aeration $\ldots \ldots \ldots \ldots \ldots \ldots \ldots \ldots \ldots \ldots \ldots$

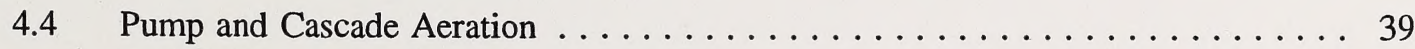

4.5 Ice-preserving/Non-mixing Aeration $\ldots \ldots \ldots \ldots \ldots \ldots \ldots \ldots \ldots \ldots$ 
4.6 Downflow Bubble Contact Aeration . . . . . . . . . . . . . . 45

4.7 Hypolimnetic Aeration $\ldots \ldots \ldots \ldots \ldots \ldots \ldots \ldots \ldots \ldots \ldots \ldots \ldots$

4.8 Sizing Methods for Lake Aeration $\ldots \ldots \ldots \ldots \ldots \ldots \ldots \ldots \ldots \ldots \ldots$

4.9 Review of Lake Aeration in Alberta $\ldots \ldots \ldots \ldots \ldots \ldots \ldots \ldots \ldots$

4.10 Evaluation of Lake Aeration Projects . . . . . . . . . . . . . 63

4.11 Summary of Winterkill Remediation Techniques $\ldots \ldots \ldots \ldots \ldots \ldots$

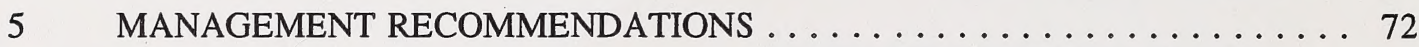

6 RESEARCH RECOMMENDATIONS $\ldots \ldots \ldots \ldots \ldots \ldots \ldots \ldots \ldots \ldots$

7 LITERATURE CITED $\ldots \ldots \ldots \ldots \ldots \ldots \ldots \ldots \ldots \ldots \ldots \ldots \ldots \ldots$ 
Table 1. Average fingerling trout stocking rates for winterkill lakes in the Peace River region of Alberta $\ldots \ldots \ldots \ldots \ldots \ldots \ldots \ldots \ldots \ldots \ldots$

Table 2. Trout population structure used to estimate the contribution of fish respiration to winter oxygen depletion $\ldots \ldots \ldots \ldots \ldots \ldots \ldots \ldots \ldots$

Table 3. Sample calculation of winter fish respiration $\ldots \ldots \ldots \ldots \ldots \ldots \ldots$

Table 4. Winter oxygen depletion attributable to fish for various combinations of fish biomass and metabolic rate $\ldots \ldots \ldots \ldots \ldots \ldots \ldots \ldots \ldots \ldots \ldots \ldots$

Table 5. Summary of lake aeration installations in Alberta $\ldots \ldots \ldots \ldots \ldots \ldots$

Table 6. Comparison of alternative winter lake aeration methods . . . . . . . . 69

Table 7. Comparative costs of alternative lake aeration methods $\ldots \ldots \ldots \ldots$ 


\section{LIST OF FIGURES}

PAGE

Figure 1. Conceptual model of metabolic responses to low oxygen. Drawn after

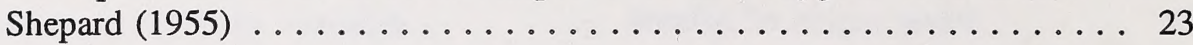

Figure 2. Theoretical time course of mortality at various oxygen concentrations ... 24

Figure 3. Compressed air lake aeration system $\ldots \ldots \ldots \ldots \ldots \ldots \ldots \ldots \ldots$

Figure 4. Kranenburg's (1979) model of water circulation patterns induced by a bubble plume in a vertically stratified lake .............. 33

Figure 5. Cross-section of a bubble plume showing vertical and horizontal water velocities at various distances from the plume ........... 35

Figure 6. Mechanical surface aerator, Air-o-later ${ }^{\circledast}$ design $\ldots \ldots \ldots \ldots \ldots \ldots$

Figure 7. Internal arrangement of baffles used in pump and cascade aeration systems .......................... 41

Figure 8. Idealized model of the ice-preserving aeration method of Ellis and Stefan (1990)

Figure 9. An ice-preserving aeration system designed by Ellis and Stefan (1990) . . 46

Figure 10. Model of a downflow bubble contact aeration (DBCA) system (modified from Seppanen 1974) . . . . . . . . . . . . . . . . . . . . 48

Figure 11. Diagram of the DBCA system installed at Newman Lake, Washington . . 49

Figure 12. A typical full air lift hypolimnetic aerator $\ldots \ldots \ldots \ldots \ldots \ldots \ldots$

Figure 13. Example of a partial air lift hypolimnetic aerator $\ldots \ldots \ldots \ldots \ldots \ldots$

\section{LIST OF PLATES}

PAGE

Plate 1. Mechanical surface aerator in operation in late February, 1994 at Logan Lake, British Columbia .................... 38

Plate 2. Pump and cascade aerators used at Oak Lake (a) and Sandy Lake (b), Manitoba, late February, 1994 


\section{ACKNOWLEDGMENTS}

The author benefited greatly from the help of numerous individuals who generously contributed their time and information during preparation of this review. I extend thanks to Ken Zelt, Dave Walty, Ed Kolodychuck, Dave Jackson, Ken Wright, Daryl Cole, and Kevin Wingert (Alberta Fish and Wildlife Services), Bill Howard (Manitoba Fisheries Branch), Ken Ashley, Brian Chan, and Eric Parkinson (British Columbia Fisheries Branch), Murray Koob (Saskatchewan Fisheries Branch), Brenda Simms (Spokane County Public Works Department), Ray Soltero (Eastern Washington State University), Chris Ellis (University of Minnesota), Doug Knauer (Wisconsin Department of Natural Resources), Bill Mackay, Janice Burke and Peter Aku (University of Alberta), Lowell Allan (Gibsons Petroleum Co., Hardisty, Alberta), Jim Leask

(Fresh Water Treatment Systems Ltd, Beaverlodge, Alberta), Dick Rogers (Arbrux Limited, Uxbridge, Ontario), Greg Lawrence (University of British Columbia), and Geoffrey Schladow (University of California, Davis).

Preparation of this review was funded by a grant from the Alberta Fisheries Habitat Development Program - Buck for Wildlife which is administered by Alberta Fish and Wildlife Services, Department of Environmental Protection. The Alberta Environmental Centre provided administrative support and allowed me the opportunity to work on this project. 


\section{EXECUTIVE SUMMARY}

Lack of oxygen results in massive winterkills of gamefish in many of Alberta's popular sportfishing lakes. Winterkill lakes are characterized by high rates of winter oxygen depletion which result from shallow depth, high productivity, and insufficient surface inflow. The primary factors contributing to winter oxygen depletion are microbial degradation of organic sediments, dead macrophytes and phytoplankton, microbial respiration in the water column, chemical oxygen consumption, and in some situations respiration by fish and other multicellular organisms. The only natural process which can add significant amounts of oxygen to ice-covered winterkill lakes is photosynthesis by phytoplankton and aquatic macrophytes. In the absence of significant snow cover, under-ice photosynthesis likely produces sufficient oxygen to prevent many winterkill events. Photosynthesis in lakes during winter is strongly inhibited by snow cover. There is a need for research to characterize winterkill lakes according to their capacity for under-ice photosynthesis and to quantify the major factors contributing to winter oxygen consumption. This information is necessary to identify the optimum type and level of winterkill remediation appropriate for individual lakes.

The severity of winterkill varies greatly according to fish species, size, and sex. Resistance to winterkill is related to small body size, morphological and behavioural adaptations for breathing the surface film, and physiological adaptations which remain poorly defined but may involve reduced oxygen requirements and enhanced anaerobic metabolism. Toxic substances such as hydrogen sulfide, ammonia, methane, and carbon dioxide which accumulate during anoxic episodes may significantly exacerbate the lethal effects of low oxygen. Field observations suggest that brook trout (Salvelinus fontinalis) and Arctic grayling (Thymallus arcticus) may survive winterkill conditions better than rainbow trout (Oncorhynchus mykiss) which are presently the dominant fish stocked in Alberta winterkill lakes. The alleged survival advantage of brook trout and grayling is attributed to lower winter oxygen requirements, but other factors, such as a better ability to find oxygenated water and a less stressful reproductive cycle, may also contribute. If future research could identify salmonid gamefish species which are more resistant to low oxygen than rainbow trout, it would provide an attractive and less expensive alternative to artificial aeration for winterkill remediation on a province-wide scale. 
The winter oxygen requirements of north-temperate freshwater fish are poorly documented because most studies have been conducted at temperatures typical of summer conditions $\left(>10^{\circ} \mathrm{C}\right)$. Furthermore, many published values for acutely lethal oxygen concentrations were derived using a technique (closed-vessel respirometry) having little validity. The capacity of gamefish to actively seek out oxygenated areas in lakes has been demonstrated under conditions of both summer and winter oxygen depletion.

Consultations and literature reviews were conducted to evaluate lake aeration as a means of rehabilitating winterkill lakes. Particular emphasis was placed on identifying; a) cost-effective alternatives to the compressed air systems currently used for lake aeration in Alberta, b) the most economically feasible method for aerating large winterkill lakes, and c) methods for predicting the size of aerated habitat created per unit aeration effort. The remediation techniques which were reviewed are snow clearing, compressed air injection, mechanical surface aeration, pump and cascade aeration, an ice-preserving/non-mixing aeration system, downflow bubble contact aeration (DBCA), and hypolimnetic aeration. The latter two methods are specialized, expensive, and best suited for improving water quality throughout the entire water volume of large lakes (DBCA), and extending fish habitat in deeper lakes (hypolimnetic aeration), rather than for winterkill remediation in the shallow lakes typical of Alberta.

Snow clearing appears to be highly effective in averting winterkill but may be economically feasible only on small farm ponds where its cost may compare favourably with that of installing electric power to operate an aeration system. Compressed air injection is the only aeration technique currently used for winterkill remediation in Alberta. When properly sized to the lake, this method is effective in maintaining high oxygen levels and averting winterkill. However, based on experiences in British Columbia, mechanical surface aerators are equally effective yet incur much lower maintenance and operating expenses compared to compressed air systems. The most economical means of averting winterkill in large lakes appears to be the pump and cascade system. In Manitoba, these systems have successfully prevented severe winterkills in lakes 7,000 acres in size. The success of pump and cascade systems is attributed to the creation of a directed current of oxygenated water which attracts fish from distances of several kilometres. Compressed air systems were not found to be effective on large lakes, presumably because they direct aerated water radially. Pump and cascade systems have a very low cost per unit of lake surface which results from their ability to attract fish to an oxygenated refuge rather 
than to aeration of the entire lake volume. Other advantages of pump and cascade systems include portability (i.e. they are suitable as emergency aeration systems) and a reduced safety hazard due to smaller areas of open water.

With compressed air and mechanical surface aerators, most of the oxygen transfer apparently occurs via atmospheric aeration across the large area of open water created by these systems. The open water area presents a potentially dangerous hazard to winter recreationists. In Minnesota, where at least six people have drowned at winter lake aeration sites, an icepreserving aeration system was developed to eliminate the open water hazard. This system is an extension of the pump and cascade aeration method and has the additional advantage of minimizing the increase in lake oxygen consumption which normally accompanies artificial aeration.

Present methods for predicting the size of aeration system required in a given lake are inadequate. Future research on this problem must address three issues: (a) the logistics of creating aerated refuges or cells in lakes; (b) the size of suitable fish habitat created per unit of aeration; and (c) the number or biomass of fish that can be successfully overwintered in that habitat. Resolving these issues will require experimental in-lake trials to elucidate the operating characteristics of the various aeration techniques and field studies to define fish attraction and behavioural responses to aeration.

It is concluded that mechanical surface aeration and pump and cascade aeration have sufficient potential to improve winterkill remediation in Alberta to warrant their use in experimental trials. 
Many of Alberta's lakes are extremely susceptible to winterkill, the massive die-off of gamefish caused by severe oxygen depletion under winter ice. Winterkill results in the loss of hundreds of thousands to millions of wild and stocked gamefish each year. Loss of these fish leads to diminished sport fishing opportunities and the expenditure of tax revenue for restocking depopulated lakes. Alberta presently has winterkill problems in more than fifty popular sport fishing lakes and hundreds of small farm ponds which have considerable potential for aquaculture. Several large lakes with surface areas of hundreds to thousands of acres also suffer severe winterkills.

Artificial aeration is currently the most effective means of rehabilitating winterkill lakes and is conducted at 12 to 14 sport fishing lakes in the province each year. However, the cost of applying existing lake aeration practices to large winterkill lakes, or to large numbers of smaller lakes, appears to be prohibitive. These considerations prompted a scientific review to identify improvements which could be made to existing aeration installations and to determine if promising cost-effective aeration techniques exist for large winterkill lakes.

The approach taken was to first review the present scientific understanding of winter oxygen depletion and the associated fish mortality for the purpose of identifying the most profitable remediation measures. Subsequently, promising aeration techniques were reviewed to assess their suitability for use in Alberta. This was done by literature review and by consultation with personnel operating selected aeration installations in other provinces and some U.S. states. Recommendations for management initiatives and future research opportunities were also identified.

Although a considerable quantity of lake aeration literature has accumulated, much of it is descriptive in nature, rather than hypothesis driven. A review of this material leads to one overriding conclusion: the operating characteristics of aeration systems in terms of oxygen dynamics, water flow patterns, and fish behavioural responses are poorly documented. Therefore, it is hoped that the information contained in this review can be revised at a future date once additional research has clarified these issues. 


\subsection{Underlying Causes}

Winterkill lakes share several characteristics, the most important being shallowness, high productivity, and little surface inflow. These appear to be the primary factors leading to high rates of winter oxygen depletion (WOD) which is the direct cause of most winterkill events. Barica and Mathias (1979) observed that winterkill lakes in SW Manitoba usually have maximum depths less than $5 \mathrm{~m}$. Those authors also demonstrated a strong, non-linear, inverse relationship between WOD rate $\left(\mathrm{g} / \mathrm{m}^{3} / \mathrm{d}\right)$ and mean depth among a wide variety of lakes (Manitoban prairie lakes, Experimental Lakes Area in NW Ontario, central Ontario lakes, and Arctic lakes) which differed in morphometry, trophic status, and other features (Mathias and Barica 1980). The inverse relationship between depth and WOD rate was most apparent at mean lake depths of less than approximately $10 \mathrm{~m}$ (Mathias and Barica 1980).

The high rate of winter oxygen depletion characteristic of shallow lakes is presumed to be a straightforward outcome of their high ratio of sediment area to lake volume (Charlton 1980). It is believed that winter oxygen depletion in shallow lakes is primarily attributable to respiration by sediment organisms (see below). According to this hypothesis, shallow lakes contain a comparatively small amount of oxygen, relative to their sediment oxygen demand, and therefore become depleted of oxygen more rapidly than deep lakes (see Fig. 2 in Mathias and Barica 1980, and Fig. 3 in Welch and Bergman 1985).

Although a significant relationship between depth and WOD rate seems undeniable, such a relationship can be difficult to detect if similar lakes within the same geographic region are compared. For example, ELA lakes exhibit a poor WOD rate-depth relationship (Schindler 1971), probably because these lakes are less productive than winterkill lakes and have significant surface inflow. A series of central Alberta lakes did not exhibit significant correlations between mean depth and WOD rate when the latter was calculated from a nonlinear decline in $\left[\mathrm{O}_{2}\right]$ over winter (Babin and Prepas 1985). The same lakes did show a significant WOD rate - depth relationship when the usual, but less accurate, assumption of linearly declining $\left[\mathrm{O}_{2}\right]$ was used to calculate WOD rate (Babin and Prepas 1985). In the latter study, a clear relationship between WOD rate and depth was probably obscured by additional factors, notably lake productivity, which also strongly influence WOD rate. 
Several studies have shown a significant relationship between WOD rate and indices of lake productivity, such as mean summer [total phosphorus] and [chlorophyll a] (Welch et al. 1976; Mathias and Barica 1980; Babin and Prepas 1985). The relationship arises at least partly from an inverse autocorrelation between lake productivity and depth. However, in the study by Mathias and Barica (1980), the effects of productivity on WOD rate were clearly evident after the effect of lake morphometry (sediment area/lake volume ratio) was accounted for. Furthermore, Babin and Prepas (1985) obtained more accurate predictions of WOD rate among lakes within and outside Alberta from a combination of lake productivity and mean depth. Therefore, the effect of productivity on WOD rate appears to be separate from that of depth.

A lack or scarcity of surface water inflow appears to be the third defining characteristic of winterkill lakes (Cooper and Washburn 1946; Barica and Mathias 1979; Babin and Prepas 1985; Ellis and Stefan 1989). Among eleven small high elevation (>2,100 m) reservoirs in SE Wyoming, winter dissolved $\left[\mathrm{O}_{2}\right]$ was significantly related to the presence or absence of inflow (Guenther and Hubert 1991). Surface inflow, whether from rainfall or a permanent stream, can be beneficial not only by supplying additional oxygen, but also by distributing oxygen away from areas of high abundance which might be created by deep water or photosynthesis under snow-free patches of ice. Groundwater usually contains little oxygen (Greenbank 1945), and therefore may actually exacerbate winter oxygen depletion. The potential of groundwater seepage into a lake to disperse oxygen from sites of production (photosynthesis or artificial aeration) has not been studied.

Although shallowness, high productivity, and lack of surface inflow are the most important factors leading to high WOD rates and winterkill risk, several additional factors exacerbate the problem. Barica and Mathias (1979) suggest that a small lake surface area (<approx. 20 acres) provides little opportunity for wind to create snow-free ice patches, and consequently increases the risk of winterkill. This suggestion has considerable merit because snow cover greatly reduces light transmittance and under-ice photosynthesis (see below). Failure to attain complete saturation of water with oxygen during fall turnover also hastens the onset of hypoxia. Incomplete reaeration during fall is typical of some lakes, notably those in central Alberta (Babin and Prepas 1985; Trimbee and Prepas 1988). In contrast, prairie lakes in SW Manitoba (Barica and Mathias 1979), and high elevation lakes in SE Wyoming apparently achieve $80-100 \%$ oxygen saturation during fall. Finally, the shallowness of many winterkill 
lakes means that winterkill risk can be significantly influenced by periods of drought. For some lakes (eg. Police Lake near Cardston, Alberta), anecdotal evidence suggests that winterkills are more likely or more severe during years of low water level.

\subsection{Oxygen Dynamics of Ice-covered Lakes}

There appear to be only three processes which can significantly raise $\left[\mathrm{O}_{2}\right]$ in lakes over winter: freeze-out of oxygen during ice formation, reaeration of water during fall overturn, and photosynthesis. Ice formed by the freezing of water at the surface of an unfrozen lake, or at the undersurface of existing lake ice, is termed black ice and is almost totally devoid of oxygen (Welch 1974; Welch and Bergman 1985). Oxygen excluded from black ice becomes dissolved in the unfrozen water whose volume has been decreased in direct proportion to the amount of ice. Black ice formation does not increase the total amount of oxygen available to lake organisms over winter, but can substantially increase water $\left[\mathrm{O}_{2}\right]$. For example, in a shallow lake having a mean depth of $5 \mathrm{~m}$ and an initial $\left[\mathrm{O}_{2}\right]$ of $10 \mathrm{mg} \mathrm{O} / \mathrm{L}$, one metre of black ice will raise the $\left[\mathrm{O}_{2}\right]$ of the unfrozen water to $12.5 \mathrm{mg} \mathrm{O} / \mathrm{L}$. Lake ice can also form as water wells up through cracks in black ice and mixes with overlying snow. This slush ice or white ice, as it is called, removes oxygen from the lake (Welch et al. 1976).

In most winterkill lakes, the amount of surface reaeration occurring before freeze-up largely determines the quantity of oxygen which becomes sealed under ice. Engineering studies with wind tunnel/water channel facilities have shown that the rate of aeration at the water surface is strongly dependent on wind velocity, the maximum effect being well over an order of magnitude (Mattingly 1977). Wind promotes reaeration by producing surface turbulence which in turn facilitates the dissolution of oxygen in water, and creates currents which bring poorly oxygenated water to the surface. Even the relatively minor turbulence created by falling raindrops can significantly increase the rate of aeration (Banks et al. 1977).

At sea level, freshwater which is fully saturated with oxygen contains $13.1 \mathrm{ppm} \mathrm{O}_{2}$ at $4^{\circ} \mathrm{C}$, and $10.2 \mathrm{ppm}_{2}$ at $15^{\circ} \mathrm{C}$ (Davis 1975). Whether wind induced aeration can fully oxygenate the entire lake depends on weather conditions and lake morphology. Deep lakes having a small surface area, steeply sloping shorelines, and which undergo hypolimnetic oxygen depletion in summer are less likely to become fully oxygenated prior to freeze-up. Lakes which become only 50 - 80\% saturated prior to freeze-up are common in central Alberta (Babin and Prepas 1985; 
Trimbee and Prepas 1988), whereas pothole lakes in Manitoba apparently achieve 80 - 100\% oxygen saturation (Barica and Mathias 1979). Variability in oxygen saturation at freeze-up results from factors such as lake surface area, depth, the height and slope of shoreline, and the extent of summer thermal stratification and hypolimnetic oxygen depletion. However, a systematic study relating these factors with the extent of fall lake reaeration has not been conducted.

Even at the low water temperatures and short daylengths typical of winter in northern latitudes, photosynthesis by planktonic algae can produce sufficient oxygen to drastically reduce the frequency and severity of winterkill. Unfortunately, under-ice photosynthesis is strongly dependent on the extent of snow and ice cover. During a winter of almost no snow cover, Barica et al. (1983) recorded an $\left[\mathrm{O}_{2}\right]$ of $27.6 \mathrm{mg} / \mathrm{L}$ (three times the normal saturation value) in a large (1720 ha), shallow (max. depth $3.8 \mathrm{~m}$ ), eutrophic lake in SW Manitoba. This lake undergoes severe winterkill in about one half of all winters, and sometimes summerkills. Strong correlations between water $\left[\mathrm{O}_{2}\right]$ and the extent of snow and ice cover have been reported frequently, both during the course of a single winter and among successive winters having different quantities of snowfall (Greenbank 1945; Cooper and Washburn 1946; Ellis and Stefan 1990). The relationship between snow and ice cover, light penetration, and photosynthesis appears to be so strong that it may be the primary factor which determines whether an individual lake will winterkill in any given year.

The development of lake ice and snow cover can be categorized into four more or less distinct phases (Prowse and Stephenson 1986). The early season phase involves the formation and growth of black ice at the lake surface. The second or mid-season phase begins with the first substantial accumulation of snow cover. Sufficient snow cover will insulate the underlying black ice and thereby slow its further growth. Eventually the weight of accumulating snow, combined with the effect of large temperature fluctuations, produces cracks in the ice through which lake water upwells. This water freezes with the lower layer of snow (a process called slushing) to produce white ice. During the third or peak-season period of cover development white ice gradually increases in thickness as the overlying layer of snow diminishes. Finally, warming air temperature during late winter initiates the fourth phase which involves wastage of snow and white ice and the exposure of underlying black ice (Prowse and Stephenson 1986). 
Light transmittance through snow and ice cover depends on the albedo, defined as the proportion of incident light which is reflected, and the extinction coefficient, which describes the attenuation of light within the cover. Freshly fallen snow has an albedo of about 0.95 , but this diminishes within hours or days to levels of 0.6 to 0.8 which are typical of dry, slightly compacted snow (Greenbank 1945; Prowse and Stephenson 1986). The albedo of white ice varies less than that of snow and ranges from 0.33 to 0.46 (Adams 1978; Bolsenga 1969,1983). Black ice and open water possess a very low albedo, about 0.1 (Bolsenga 1969). Snow exhibits high extinction coefficients (indicating a rapid attenuation of light) ranging from 40 for freshly fallen snow, to 25 for dry, compact snow, to 10 for melting snow (Thomas 1963; Grenfell and Maykut 1977; Adams 1978). White and black ice have extinction coefficients of approximately 4 and 2 respectively (Grenfell and Maykut 1977).

Prowse and Stephenson (1986) used the above albedo and extinction coefficients together with measurements of snow and ice depth to estimate light intensities reaching the surface of Coon Lake, Ontario. When only black ice was present ( $0.25 \mathrm{~m}$ in thickness), the percentage of incident radiation transmitted to the lake (denoted hereafter as I\%) was approximately $55 \%$. This amounts to $61 \%$ of the light which would have entered the lake in the absence of ice. Owing to the very high albedo and extinction coefficient of snow, minimum light transmittance occurred in the second phase of cover development, once significant snow cover had accumulated, but before white ice formation had begun. At the first snowfall of $40 \mathrm{~mm}$, I\% was decreased to 7.0. Once snow had reached depths of 0.12 and $0.25 \mathrm{~m}$, I\% was reduced to 1.0 and $<0.1$ respectively (Prowse and Stephenson 1986). The subsequent formation of white ice significantly improved light transmittance. Conversion of $80 \%$ of the snow cover (i.e. $0.2 \mathrm{~m}$ ) to white ice raised $1 \%$ to 1.3; complete replacement of $0.25 \mathrm{~m}$ snow with white ice raised $\mathrm{I} \%$ to 12.6 . The latter situation would occur during the final phase of cover development (wastage).

Because only a few centimetres of snow are required to reduce light transmittance to very low levels, photosynthesis under ice depends critically on the duration of snow cover. Therefore, winterkill is likely to be most severe in years of early and heavy snowfall. Heavy snow accumulation not only reduces light transmittance, but also insulates black ice from the large temperature changes necessary to initiate cracking and white ice formation (Prowse and Stephenson 1986). Conversely, the absence of snow cover over black ice provides the opportunity for substantial oxygen production through photosynthesis. This is why the $\left[\mathrm{O}_{2}\right]$ of 
many lakes continues to increase for some time after freeze-up (Barica and Mathias 1979; Jackson and Lasenby 1982; Barica et al. 1983).

Most of the under-ice oxygen depletion in winterkill lakes has been attributed to bacterial respiration in the sediments rather than to oxygen consumption in the water column. This view appears to have become dogma even though it has never been definitively supported with experimental data. The perceived importance of sediment oxygen demand (SOD) as the primary cause of winter oxygen depletion arises from uncritical acceptance of certain types of inconclusive or misleading data. For example, at least two studies (Mathias and Barica 1980; Welch and Bergmann 1985) have attempted to estimate water column oxygen demand from empirical relationships between volumetric WOD rate and lake sediment area/volume ratio. The $\mathrm{Y}$ intercept corresponds to the WOD of an infinitely large lake with no sediment area and is attributed entirely to oxygen consumption within the water column. Water oxygen demands derived in this manner are an insignificant fraction of estimated SOD (Mathias and Barica 1980; Welch and Bergmann 1985). Unfortunately, such an analysis does not give accurate estimates of water oxygen demand because it is based on the erroneous assumption that water oxygen demand is unrelated to sediment area/lake volume ratio. In actual fact, as sediment area/volume ratio increases, lakes become increasingly shallow and more productive. Lakes of high productivity will generally contain greater concentrations of plankton, bacteria, and suspended detritus, and should therefore exhibit higher water oxygen demands. Mathias and Barica (1980) did perform separate analyses on oligotrophic and eutrophic lakes. However, the productivity of lakes within each of these two groups still varied considerably, the more productive ones probably being those with higher sediment area/lake volume ratios. Therefore, separate analyses on lakes differing in trophic status does not validate use of the $\mathrm{Y}$ intercept to derive water oxygen consumption.

Vertical profiles of $\left[\mathrm{O}_{2}\right]$ measured several times during winter often indicate a more rapid depletion of oxygen closer to the sediments (Greenbank 1945; Jackson and Lasenby 1982). This observation has also been used to infer that SOD was the predominant cause of WOD. However, vertical gradients in $\left[\mathrm{O}_{2}\right]$ can also result from freeze-out, low level photosynthesis just beneath the ice cover, and by the decomposition of sedimenting organic matter (dead plankton and debris). Cessation of wind-induced turbulence by formation of ice cover normally allows 
suspended organic matter to settle. With increasing depth, water will be in progressively longer contact with this settling matter, and hence experience greater oxygen depletion.

A third method used to infer the importance of sediments in winter oxygen depletion is the respiration rate of sediment cores, or in situ measurement of sediment oxygen consumption using flux chambers embedded in the lake bed (Hargrave 1969, 1972a; Brewer et al. 1977). Under such experimental conditions, the sediments of shallow, eutrophic lakes have more than enough oxygen demand to account for observed rates of winter oxygen depletion. However, under natural conditions, biological and chemical processes in the water column have the first opportunity to consume oxygen. Thus, the considerable capacity of sediments to consume oxygen can only be maximally expressed if oxygen consumption in the water column is sufficiently low. In one of the few studies to quantify both water and sediment oxygen demand, Linsey and Lasenby (1985) found oxygen consumption in the water column (winter $=0.032 \mathrm{mg}$ $\mathrm{O}_{2} / \mathrm{L} / \mathrm{d}$, summer $=0.027 \mathrm{mg} \mathrm{O} / \mathrm{L} / \mathrm{d}$ ) to exceed that in the sediments (winter $=0.018 \mathrm{mg} \mathrm{O}_{2} / \mathrm{L} / \mathrm{d}$, summer $=0.020 \mathrm{mg} \mathrm{O} / \mathrm{L} / \mathrm{d}$ ). Although the latter study was conducted in a relatively deep bay (mean depth=16.1 m, max. depth=43 m), and may not be representative of most winterkill lakes, it does emphasize the importance of quantifying oxygen consumption in the water column.

Although the importance of sediments to winter oxygen depletion in winterkill lakes has never been definitively quantified, research has examined the dependence of sediment oxygen demand on various physical, chemical, and hydrological factors. As expected, increasing temperature and water velocity next to the sediment surface increase the rate of sediment oxygen consumption (McDonnell and Hall 1969; Belanger 1981; Boynton et al. 1981). Dissolved oxygen concentration begins to slow the rate of sediment oxygen consumption once $\left[\mathrm{O}_{2}\right]$ in near-sediment water declines below about 3-4 $\mathrm{mg} \mathrm{O}_{2} / \mathrm{L}$. This has been demonstrated in incubated sediment cores (Hargrave 1972a; Graneli 1978), and been inferred from declines in the rate of winter oxygen depletion in prairie lakes once $\left[\mathrm{O}_{2}\right]$ fell below about $3 \mathrm{mg} \mathrm{O} / \mathrm{L}$ (Mathias and Barica 1980; Ellis and Stefan 1989). Oxygen depletion occurs only in a thin oxidized microzone at the sediment surface (Hargrave 1972b; Jorgensen and Revsbech 1985). The depth of this oxidized microzone varies with sediment particle size and organic content, being about $1 \mathrm{~cm}$ in organically rich lake mud, and $3 \mathrm{~cm}$ in sand from the same lake (Hargrave 1972b). The magnitude of oxygen consumption differs considerably among sediments from different lakes (Lonnerblad 1930), as does the relative contributions of biological and chemical oxidation (Hargrave 1972b). 
Chemical oxygen consumption is that which is attributable to specific chemical processes other than the oxidation of organic compounds by cellular respiration (i.e. $\mathrm{CH}_{2} \mathrm{O}+\mathrm{O}_{2}-\rightarrow \mathrm{CO}_{2}$ $+\mathrm{H}_{2} \mathrm{O}$ ). Processes such as nitrification, denitrification, methane oxidation, and the oxidation of manganese, iron, and sulfides are included in chemical oxygen consumption (Vigil 1992). Most of these processes are probably accelerated by the metabolism of autotrophic or heterotrophic bacteria. Although few studies have examined chemical oxygen consumption in winterkill lakes, it appears to make a significant contribution to winter oxygen depletion. In a mesotrophic lake in southern Ontario, nitrification accounted for about $71 \%$ of winter oxygen depletion (Knowles and Lean 1987). Chemical oxidation, perhaps accelerated by light, is most likely to be significant in lakes with much dissolved organic carbon (Hutchinson 1957). Such conditions are typical of stained bog lakes which receive large amounts of dissolved humic acids. Chemical oxygen demand may also explain why artificial aeration is seldom successful if initiated after anoxic conditions have been allowed to develop. In this situation, much of the oxygen introduced by the aeration system is probably consumed in the oxidation of reduced compounds released from anoxic sediments and therefore not available to increase dissolved oxygen concentration (Taggart and McQueen 1982; Ashley 1987).

Aside from a few studies on fish (see next section), the proportion of winter oxygen depletion attributable to multicellular organisms such as zooplankton, plants, and benthic invertebrates has not been quantified.

\subsection{The Role of Fish Respiration in Winter Oxygen Depletion}

It is commonly believed that fish respiration makes an insignificant contribution to winter oxygen depletion in ice-covered lakes. This view may have originated from the study by Greenbank (1945) who calculated that a typical pond in southern Michigan containing $14 \mathrm{mg}$ $\mathrm{O}_{2} / \mathrm{L}$ could meet the winter oxygen requirements of its fish population for more than 700 days. However, a re-evaluation of fish respiration in winterkill lakes was undertaken due to the scarcity of information on oxygen consumption by wild fish populations and the large geographic variation in the length of winter ice cover.

The potential contribution of fish respiration to winter oxygen depletion in northern Alberta lakes was assessed using information on fingerling stocking rates and growth rates for aerated lakes in the Peace River region. Table 1 shows the average number of fingerlings 
stocked per year in each lake since stocking records were first kept (information supplied by E. Kolodychuk). The six largest aerated lakes received an average of 3,817 fingerlings per year per $100,000 \mathrm{~m}^{3}$ of lake water (Table 1). Fish density and biomass was estimated using growth rates typical of rainbow trout in the aerated lakes, and a survival rate of $50 \%$ per year (Table 2). These conditions will result in an average trout density of $3,105 \mathrm{~kg}$ per $100,000 \mathrm{~m}^{3}$ of water after four years of stocking (Table 2).

Routine oxygen consumption rates of salmonid fish under winter conditions have not been well quantified. In the absence of this information, a value of $40 \mathrm{mg} \mathrm{O} / \mathrm{kg} / \mathrm{hr}$ seems a reasonable approximation. At that rate of respiration, the oxygen concentration of a $100,000 \mathrm{~m}^{3}$ lake would decline by $4.47 \mathrm{mg} \mathrm{O}_{2} / \mathrm{L}$ over a five month period (Table 3 ). Thus, fish respiration can reduce lake oxygen levels which were $10 \mathrm{mg} \mathrm{O} / \mathrm{L}$ at freeze-up to $5.53 \mathrm{mg} \mathrm{O} / \mathrm{L}$ by the following spring. Furthermore, remember that the fish density used in these calculations $(3,105$ $\left.\mathrm{kg} / 100,000 \mathrm{~m}^{3}\right)$ is an average value. Cummings and Poirier's lakes which had nearly twice the average stocking rate (Table 1) would have correspondingly higher oxygen depletion rates.

Although Greenbank (1945) concluded that fish respiration makes little contribution to winter oxygen depletion, a re-working of his calculations leads to the opposite conclusion. Greenbank (1945) assumed a lake volume of $9.9 \times 10^{6} \mathrm{~L}$, a fish biomass of $226.8 \mathrm{~kg}$, and an oxygen consumption rate of $35.8 \mathrm{mg} \mathrm{O}_{2} / \mathrm{kg} / \mathrm{hr}$. Surprisingly, the biomass density which Greenbank (1945) took as representative of shallow productive lakes in Michigan (2,291 $\left.\mathrm{kg} / 100,000 \mathrm{~m}^{3}\right)$ is fairly close to the value estimated for lakes in northern Alberta $(3,105$ $\mathrm{kg} / 100,000 \mathrm{~m}^{3}$ ). Calculations based on Greenbanks (1945) assumptions indicate that over a five

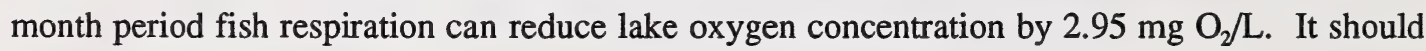
also be remembered that once $\left[\mathrm{O}_{2}\right]$ declines to very low levels $(<2 \mathrm{mg} \mathrm{O} / \mathrm{L})$, fish respiration may be significant in removing the remaining oxygen, particularly if fish are concentrated within small portions of the lake.

The above analyses suggest that fish respiration can make a significant contribution to winter oxygen depletion in shallow productive lakes. However, a more definitive analysis of this issue is needed. This will require accurate measurement of fish biomass in stocked lakes and the routine oxygen consumption of fish under winter conditions. Table 4 is a guide to the winter oxygen depletion which would result from various combinations of fish biomass and average metabolic rate. 
Table 1. Average fingerling trout stocking rates for winterkill lakes in the Peace River region of Alberta

\begin{tabular}{||c|c|c|c|c|c|}
\hline \multirow{2}{*}{ Lake } & \multirow{2}{*}{$\begin{array}{c}\text { Surface } \\
\text { area }\end{array}$} & \multirow{2}{*}{$\begin{array}{c}\text { Lake } \\
\text { Volume }\end{array}$} & \multicolumn{3}{|c|}{ Average yearly stocking rates } \\
\cline { 5 - 6 } & (hectares) & $\left(\mathrm{m}^{3}\right)$ & \# fish & \# fish/ha & $\begin{array}{c}\text { \# fish/ } \\
100,000 \mathrm{~m}^{3}\end{array}$ \\
\hline Figure Eight & 38.6 & $1,153,356$ & 27,884 & 722 & 2,418 \\
\hline Spring & 32.0 & $2,505,816$ & 29,905 & 935 & 1,193 \\
\hline Moonshine & 30.8 & 493,394 & 36,411 & 1,182 & 7,380 \\
\hline Cummings & 24.0 & 485,624 & 19,449 & 810 & 4,005 \\
\hline E. Dollar & 4.9 & 194,248 & 1,999 & 408 & 1,029 \\
\hline Poirier's & 3.4 & 33,589 & 2,310 & 679 & 6,877 \\
\hline Zama & 2.0 & 120,963 & 359 & 180 & 297 \\
\hline
\end{tabular}

Average \# fingerlings stocked per year per $100,000 \mathrm{~m}^{3}$ (excluding Zama pond) $=3,817$

Table 2. Trout population structure used to estimate the contribution of fish respiration to winter oxygen depletion

\begin{tabular}{|c|c|c|c|c|c|c|c|c|}
\hline \multirow{2}{*}{ Cohort } & \multicolumn{5}{|c|}{ Number of fish of each cohort present in lake } & \multirow{2}{*}{ Age } & \multirow{2}{*}{$\begin{array}{l}\text { Average } \\
\text { weight }^{2} \\
(\mathrm{~kg})\end{array}$} & \multirow{2}{*}{$\begin{array}{l}\text { Total wt } \\
\text { of cohort } \\
(\mathrm{kg})\end{array}$} \\
\hline & start & year 1 & year 2 & year 3 & year 4 & & & \\
\hline 1 & 3,817 & 1,909 & 955 & 478 & 239 & 4 & 2.0 & 478 \\
\hline 2 & 0 & 3,817 & 1,909 & 955 & 478 & 3 & 1.5 & 717 \\
\hline 3 & 0 & 0 & 3,817 & 1,909 & 955 & 2 & 1.0 & 955 \\
\hline 4 & 0 & 0 & 0 & 3,817 & 1,909 & 1 & 0.5 & 955 \\
\hline
\end{tabular}

${ }^{1}$ Population structure was calculated assuming a lake volume of $100,000 \mathrm{~m}^{3}$, fingerling stocking rates of 3,817 per year, and an annual survival rate of $50 \%$.

${ }^{2}$ Weights at age are representative of rainbow trout in aerated lakes in the Peace River region. 
Table 3. Sample calculation of winter fish respiration

1. Volume of lake in litres $=1 \times 10^{8} \mathrm{~L}$

calculation: $100,000 \mathrm{~m}^{3} \times 1,000 \mathrm{~L} / \mathrm{m}^{3}=1 \times 10^{8} \mathrm{~L}$

2. Oxygen consumption by fish over 5 month winter period $=4.47 \times 10^{8} \mathrm{mg} \mathrm{O}_{2}$

assumptions: fish oxygen consumption rate $=40 \mathrm{mg} \mathrm{O}_{2} / \mathrm{kg} / \mathrm{hr}$ calculations:

total weight of fish in lake $=3,105 \mathrm{~kg}$ (from Table 2)

5 months X 30 days $/ \mathrm{mo}$ X $24 \mathrm{hr} /$ day X $40 \mathrm{mg} \mathrm{O} / \mathrm{kg} / \mathrm{hr} \times 3,105 \mathrm{~kg}=4.47 \times 10^{8} \mathrm{mg} \mathrm{\textrm {O } _ { 2 }}$

3. Decline in lake oxygen concentration attributable to fish respiration $=4.47 \mathrm{mg} \mathrm{O}_{2} / \mathrm{L}$

calculation: $4.47 \times 10^{8} \mathrm{mg} \mathrm{O}_{2} / 1 \times 10^{8} \mathrm{~L}=4.47 \mathrm{mg} \mathrm{O}_{2} / \mathrm{L}$

Table 4. Winter oxygen depletion attributable to fish for various combinations of fish biomass and metabolic rate

\begin{tabular}{||c|c|c|c|c|c|c||}
\hline \hline \multirow{2}{*}{$\begin{array}{c}\text { Metabolic } \\
\text { Rate (mg } \\
\left.\mathrm{O}_{2} / \mathrm{kg} / \mathrm{hr}\right)\end{array}$} & \multicolumn{7}{|c|}{ Fish Biomass $\left(\mathrm{kg} / 100,000 \mathrm{~m}^{3}\right.$ lake volume) } \\
\cline { 2 - 7 } & 250 & 500 & 1,000 & 2,000 & 3,000 & 6,000 \\
\hline 10 & $0.09^{1}$ & 0.18 & 0.36 & 0.72 & 1.08 & 2.16 \\
\hline 20 & 0.18 & 0.36 & 0.72 & 1.44 & 2.16 & 4.32 \\
\hline 30 & 0.27 & 0.54 & 1.08 & 2.16 & 3.24 & 6.48 \\
\hline 40 & 0.36 & 0.72 & 1.44 & 2.88 & 4.32 & 8.64 \\
\hline 60 & 0.54 & 1.08 & 2.16 & 4.32 & 6.48 & 12.96 \\
\hline 80 & 0.72 & 1.44 & 2.88 & 5.76 & 8.64 & 17.28 \\
\hline 100 & 0.90 & 1.80 & 3.60 & 7.20 & 10.80 & 21.60 \\
\hline \hline
\end{tabular}

${ }^{1}$ Values represent the decline in lake oxygen concentration $\left(\mathrm{mg} \mathrm{O}_{2} / \mathrm{L}\right)$ which would occur as a result of fish respiration over a five month (150 day) period of ice cover

\section{$2.4 \quad$ Summary}

The high rates of WOD characteristic of winterkill lakes result from shallow depth, high productivity, and a lack of surface water inflow. Great variability in WOD rate exists among individual winterkill lakes and among successive years within the same lake. The dominant factors contributing to variability in WOD rates are the quantity and quality of sediments and 
decaying matter, the duration and characteristics of snow cover, chemical oxygen demand, phytoplankton and macrophyte abundance (i.e. the potential for under-ice photosynthesis), and possibly respiration by fish and other multicellular organisms. No study of winterkill has simultaneously examined all the important factors which influence WOD.

Efficient winterkill remediation on a province wide scale will require better characterization of winterkill lakes in terms of those variables which determine WOD rate. Such a characterization would help fishery managers distinguish between those lakes likely to benefit from mild treatment, such as snow clearing or stocking with hypoxia resistant gamefish species, from those which require more intensive treatment in the form of aeration. The contribution of fish respiration to WOD also needs clarification because this has implications for stocking strategies in winterkill lakes.

\section{WINTER MORTALITY OF FISH}

\subsection{Modus Operandi}

Although starvation and environmental toxins such as hydrogen sulfide, ammonia, carbon dioxide, and methane may be significant modifying factors (see below), the primary stressor resulting in winter fish mortality is a lack of oxygen (Greenbank 1945; Cooper and Washburn 1949). Measurements of $\left[\mathrm{O}_{2}\right]$ prior to, and during, winterkill events give an approximate indication of how severe oxygen depletion must be to kill fish. Such measurements suggest that severe winterkills are rare unless $\left[\mathrm{O}_{2}\right]$ declines below about $2.0 \mathrm{mg} \mathrm{O} / \mathrm{L}$ (Greenbank 1945; Cooper and Washburn 1949). More resistant species, such as pike and bullheads, may not experience severe winterkill until $\left[\mathrm{O}_{2}\right]$ declines below $1.0 \mathrm{mg} \mathrm{O} / \mathrm{L}$ (Cooper and Washburn 1949; Petrosky and Magnuson 1973; Casselman and Harvey 1975). Unfortunately, the risk of winterkill depends not only on instantaneous $\left[\mathrm{O}_{2}\right]$, but also on the length of time fish are exposed to hypoxic conditions. Previous field measurements were not sufficient to accurately quantify the latter parameter.

Even in severe winterkills which cause a nearly total collapse of gamefish populations, a few fish nearly always survive (Greenbank 1945; Cooper and Washburn 1949; Petrosky and Magnuson 1973). Furthermore, apparently healthy fish are often observed in areas of nearly anoxic water $\left(<1.0 \mathrm{mg} \mathrm{O}_{2} / \mathrm{L}\right)$. This suggests that winterkill is a selective process which varies 
in severity according to fish species, size, and sex, among other variables. In southern Michigan winterkill lakes, mortalities were highest for largemouth bass and bluegills, intermediate for yellow perch, chubsuckers, and northern pike, and least for bullheads and golden shiners (Cooper and Washburn 1949). Several small species, including brook stickleback, redbelly dace, central mudminnow, finescale dace, Iowa darter, blacknose shiner, and fathead minnow, are well known for being extremely resistant to winterkill, and are often the only fish species found in lakes that winterkill frequently (Klinger et al. 1982; Magnuson et al. 1985).

Physiological, morphological, and behavioural factors contribute to inter-species differences in winterkill survival. Small body size has considerable survival value in those species most resistant to winterkill. Magnuson et al. (1985) found that blacknose dace, redbelly dace, fathead minnows, and Iowa darters emigrated in large numbers from a Wisconsin winterkill lake in fall and returned in spring. This tactic would be less successful in large species because they would be more crowded and susceptible to predation in the small inlet and outlet streams of winterkill lakes. Small body size also facilitates the use of oxygenated microzones next to the ice-water interface and near gas bubbles trapped under the ice. Lewis (1970) suggested that $\left[\mathrm{O}_{2}\right]$ could decline from saturation to anoxia within $1 \mathrm{~mm}$ of the water surface even in situations where there was no detectable oxygen in deeper waters. Klinger et al. (1982) found that gas bubbles located near muskrat dens contained oxygen levels up to $11 \%$, much greater than that of the surrounding water. Such gas bubbles substantially increased the survival time of brook stickleback, fathead minnows, and central mudminnows when the latter were held inside in-lake enclosures (Klinger et al. 1982). However, the means used to exploit gas bubbles differed between species. The flat head and upturned mouth of brook sticklebacks allowed this species to skim the narrow film of oxygenated water next to gas bubbles and the ice-water interface. Sticklebacks and central mudminnows demonstrated superior abilities to detect microgradients of oxygen. Mudminnows were observed to actively pump water downward through simulated ice-cracks, and sticklebacks positioned their mouths next to the mudminnow's gill clefts. Central mudminnows were also found to be facultative air breathers; they engulfed air bubbles and subsequently transferred them to the swim bladder which was used as an accessory respiratory organ. Fathead minnows may also have engulfed air bubbles (although they were never observed to do so), but more likely relied on oxygen diffusing from air bubbles into the surrounding water. Among the three species which Klinger et al. (1982) studied, fathead minnows were unique in 
having the highest weight-specific metabolic rate and the longest survival time in the absence of air bubbles. Klinger et al. (1982) suggested that fathead minnows may have an increased capacity for anaerobic glycolysis which seems to be a common feature of cyprinid fish.

Morphological and behavioural factors also appear to contribute to differences in winterkill survival among large gamefish species. Magnuson and Karlen (1970) observed the reactions of northern pike, yellow perch, and bluegill sunfish to progressive hypoxia in a $1.6 \mathrm{~m}$ winterkill lake in Wisconsin. All three species moved higher in the water column as $\left[\mathrm{O}_{2}\right]$ declined below $1 \mathrm{ppm}$. However, bluegills always remained about 9 to $14 \mathrm{~cm}$ below the ice, and were thus least able to use the oxygenated surface film. Pike would rest with their mouths almost touching the ice, and their opercular movements created sufficient water current to melt domes in the ice surface. These domes eventually became about $5 \mathrm{~cm}$ deep and $30 \mathrm{~cm}$ in diameter. The morphological and behavioural differences observed by Magnuson and Karlen (1970) were well correlated with survival time, this being longest in pike and shortest in bluegills. Gee et al. (1977) monitored behavioural responses to progressive hypoxia in 26 temperate freshwater species while the latter were held in captivity. Water temperature was $16.5^{\circ} \mathrm{C}$, except for Arctic char $\left(10^{\circ} \mathrm{C}\right)$ and lake whitefish $\left(7^{\circ} \mathrm{C}\right)$. In response to low oxygen, all species rose higher in the water column, and attempted to ventilate from the surface film, except the salmonids (rainbow trout and Arctic char), lake whitefish, and walleye. Walleye are known to be negatively phototactic and may have avoided the water surface for that reason. These behavioural differences may help explain why self sustaining populations of trout, lake whitefish, or walleye are seldom found in lakes with a history of winterkill.

Several studies report higher winterkill mortalities among larger individuals of the same species (Bennett 1948; Ricker 1949; Casselman and Harvey 1975). The most thorough examination of selective winterkill is that of Casselman and Harvey (1975) who observed that partial winterkills in two Manitoulin Island lakes preferentially eliminated pike over $39 \mathrm{~cm}$ in length, and females rather than males. Plausible explanations for this selective mortality include the following.

1. The size at which mortality increases $(39 \mathrm{~cm})$ corresponds approximately to the size at which pike attain reproductive maturity. Increased oxygen requirements associated with gonadal maturation, and the attendant activities of feeding and digestion, may explain why mortalities were higher in large pike and in females. 
2. Faster growing pike may possess higher metabolic rates and hence higher oxygen requirements.

3. Small fish may acclimate more quickly to hypoxic conditions (see Shepard 1955).

4. A decreasing ratio of gill surface area to body mass with increasing body size may decrease the fish's ability to absorb oxygen. This hypothesis requires more careful formulation because decreased gill area with increasing size is accompanied by decreased oxygen demand (ie: lower weight specific metabolic rate).

5. Small pike may be better able to use the thin layer of oxygenated water located just below the ice surface.

6. Large pike probably deplete the oxygen in their immediate vicinity more rapidly than small pike. In the absence of significant water currents under ice cover, large pike may need to move more frequently to find oxygenated water, and thereby increase their cumulative exposure to low oxygen.

Finally, it should be noted that winterkill has been observed to affect not only fish but also frogs, tadpoles, mussels, crayfish, and possibly aquatic insects (Greenbank 1945). Some of the non-piscine animals affected by winterkill may be endangered species, and thus worthy of protection in their own right.

\subsection{Complicating Factors $-\mathrm{H}_{2} \mathrm{~S}, \mathrm{NH}_{3}, \mathrm{CO}_{2}, \mathrm{CH}_{4}$, Starvation}

Anoxia often initiates the release of several toxic compounds from organic lake sediments. These compounds may include ammonia, carbon dioxide, methane and hydrogen sulfide. Whether these toxins significantly exacerbate the lethal effects of low oxygen in winterkill lakes remains an open question. Greenbank (1945) concluded that the role of poisonous substances in winterkill could not be adequately assessed from the existing literature. This issue appears to have received little subsequent study. An early study by Scidmore (1957) reported that among six lakes in Minnesota, concentrations of $\mathrm{H}_{2} \mathrm{~S}, \mathrm{CO}_{2}$, and $\mathrm{NH}_{3}$ did not appear to be related to the incidence or severity of winterkill. Unfortunately, that study suffered from several shortcomings. Scidmore (1957) did not measure water $\mathrm{pH}$, and was probably unaware that the toxicity of $\mathrm{H}_{2} \mathrm{~S}$ and $\mathrm{NH}_{3}$ is greatly dependent on $\mathrm{pH}$ (see below). Furthermore, the additive effects of the three toxins was not considered, and only the instantaneous concentration of each compound, rather than cumulative exposure, was compared between lakes. 
Hydrogen sulphide in solution dissociates into the hydrosulphide anion (HS-) and the bisulphide anion $\left(\mathrm{S}^{2-}\right)$. However, the undissociated compound is the one which diffuses freely across biological membranes and has the greatest toxicity. Declining $\mathrm{pH}$ increases the proportion of $\mathrm{H}_{2} \mathrm{~S}$ in the undissociated form and thereby heightens sulphide toxicity.

The early concept that naturally occurring concentrations of $\mathrm{H}_{2} \mathrm{~S}$ have little toxic effect on fish populations has been challenged by Smith and Oseid (1973). Those authors found that concentrations of undissociated $\mathrm{H}_{2} \mathrm{~S}$ from 0.0014 to $0.0128 \mathrm{mg} / \mathrm{L}$ adversely affected the spawning behaviour and egg production of eight freshwater fish species. In fry, 48 to 96 hour LC50's ranged from 0.013 to $0.031 \mathrm{mg} \mathrm{H}_{2} \mathrm{~S} / \mathrm{L}$. Several studies have reported natural $\mathrm{H}_{2} \mathrm{~S}$ concentrations ranging from 0.02 to $0.22 \mathrm{mg} / \mathrm{L}$ (Colby and Smith 1967; Adelman and Smith 1970; Smith and Oseid 1973). Hydrogen sulphide levels reported by Scidmore (1957) were 0.3 to $0.4 \mathrm{mg} / \mathrm{L}$, and Magnuson and Karlen (1970) reported levels up to $4.0 \mathrm{mg} / \mathrm{L}$, although these levels probably refer to total sulfides. On this basis, Smith and Oseid (1973) concluded that the environmental implications of $\mathrm{H}_{2} \mathrm{~S}$ in aquatic habitats should be re-examined.

Ammonia is one of the most common toxins in aquatic environments. Many authors use the term ammonia to collectively denote both the ammonium ion $\left(\mathrm{NH}_{4}^{+}\right)$and un-ionized ammonia $\left(\mathrm{NH}_{3}\right)$. The accumulation of both $\mathrm{NH}_{3}$ and $\mathrm{NH}_{4}{ }^{+}$in lake bottom waters during anoxic episodes results principally from two processes. First, nitrification ceases in the absence of oxygen which allows $\mathrm{NH}_{3}$ produced by organic decomposition to accumulate. Second, reducing conditions created by lack of oxygen allows adsorbed $\mathrm{NH}_{4}^{+}$to be released from sediment particles (Hutchinson 1957).

As with $\mathrm{H}_{2} \mathrm{~S}$, it is the un-ionized form of ammonia which is toxic (Wuhrmann and Woker 1948; E.I.F.A.C. 1973). The relative proportions of $\mathrm{NH}_{3}$ and $\mathrm{NH}_{4}{ }^{+}$present in solution depend primarily on $\mathrm{pH}$ and temperature, with the un-ionized form being favoured by high $\mathrm{pH}$ and high temperature (Trussell 1972). Although it is generally agreed that high $\mathrm{pH}$ increases ammonia toxicity by increasing the proportion of $\mathrm{NH}_{3}$ in solution (Downing and Merkens 1955; Trussell 1972; E.I.F.A.C. 1973), the effect of temperature is less certain. Studies by Burrows (1964) and Brown (1968) suggest that the toxicity of un-ionized ammonia increases at low temperatures thereby negating the beneficial effect that decreasing temperature has on the $\mathrm{NH}_{3} / \mathrm{NH}_{4}{ }^{+}$ratio. The toxicity of ammonia to fish is increased by low $\left[\mathrm{O}_{2}\right]$ (Downing and Merkens 1955; Merkens and Downing 1957; Thurston et al. 1981). Carbon dioxide and salinity also influence ammonia 
toxicity, but their effects are more complex (Alabaster and Herbert 1954; Lloyd and Herbert 1960; Alabaster et al. 1979).

Several studies, mostly using closed-vessel respirometry, have examined the effect of $\mathrm{CO}_{2}$ on the resistance of fish to low oxygen. Fry et al. (1947) showed clearly that high levels of $\mathrm{CO}_{2}$ impair the ability of goldfish to lower the $\left[\mathrm{O}_{2}\right]$ in a sealed container. This was clearly a threshold effect; below a critical level $\mathrm{CO}_{2}$ had no effect, whereas $\mathrm{CO}_{2}$ levels above the critical value sharply increased the minimum residual $\left[\mathrm{O}_{2}\right]$. Rather surprisingly, fish appear to be more sensitive to $\mathrm{CO}_{2}$ at low temperatures. At $1^{\circ} \mathrm{C}$ the threshold $\mathrm{CO}_{2}$ partial pressure which impairs oxygen uptake in goldfish was about $80 \mathrm{~mm} \mathrm{Hg}$, whereas at $32^{\circ} \mathrm{C}_{\text {a }} \mathrm{CO}_{2}$ partial pressure of 200 $\mathrm{mm} \mathrm{Hg}$ was required to significantly increase the minimum residual $\left[\mathrm{O}_{2}\right]$ (Fry et al. 1947). Such an increased sensitivity to a toxin with declining temperature seems unusual and may be an artifact arising from closed-vessel respirometry. At low temperature, fish asphyxiate more slowly; consequently $\mathrm{CO}_{2}$ has more time to exert toxic effects. Fry (1939) and Black (1940) concluded that fish from cold habitats (e.g. common sucker) were more sensitive to $\mathrm{CO}_{2}$ than those from warm habitats (e.g. brown bullhead). Moreover, the ability of hemoglobin to bind oxygen was more sensitive to inhibition by $\mathrm{CO}_{2}$ in cold adapted species (Black 1940). In view of its rather peculiar temperature dependency, the relationship between $\mathrm{CO}_{2}$ and low oxygen resistance merits a re-examination with modern techniques.

Methane is another potentially toxic substance produced in large quantities in the anoxic sediments of shallow productive lakes and wetlands (Rudd and Hamilton 1975; Kelly and Chynoweth 1980; Miller and Oremland 1988; Wilson et al. 1989). Methane production begins with the fermentative breakdown of proteins, fats, and carbohydrates to simple organic acids and $\mathrm{CO}_{2}$ by a variety of facultative and obligatorily anaerobic bacteria (Wetzel 1975). Strictly anaerobic methanogenic bacteria then convert these organic acids and $\mathrm{CO}_{2}$ to methane. Methane concentrations in the water column frequently do not reflect the large quantities of methane produced in the sediments because of the presence of methane oxidizing bacteria in the aerobic sediment surface and water column. During summer, methane produced in the sediments can also be released to the atmosphere via diffusive flux, transport through the vascular systems of aquatic plants, and by ebullition (formation of bubbles which rise to the surface) (Wetzel 1975; Wilson et al. 1989). In winter however, anoxic conditions and ice cover may create conditions 
suitable for the accumulation of methane in the water column. Unfortunately, the toxicity of methane to fish has not been well studied.

In conclusion, because toxins such as $\mathrm{H}_{2} \mathrm{~S}, \mathrm{NH}_{3}, \mathrm{CH}_{4}$, and $\mathrm{CO}_{2}$ are byproducts associated with anoxic conditions, special techniques for their removal (other than the provision of oxygen in near sediment water), do not appear to be necessary. However, the presence of poisonous gases has at least two important implications. First, it underscores the need to verify fish oxygen requirements derived in laboratory experiments with confirmatory in-lake measurements. Second, if these substances are subsequently found to significantly exacerbate the effects of low oxygen in winterkill lakes, then their measurement may be a useful aid in predicting winterkill events.

Insufficient food intake during winter is a significant cause of mortality in several northtemperate fish species (Post and Evans 1989; Johnson and Evans 1990, 1991; Philipp and Whitt 1991). However, for most of the species affected by winterkill in Alberta, winter starvation does not appear to be an important complicating factor. Stocked salmonids in many of our winterkill lakes such as Spring Lake (near Grand Prairie), Cow Lake, and Police Outpost Lake exhibit very fast growth due to an abundance of under-exploited invertebrate food organisms. Yellow perch may be one of the rare species in which insufficient food contributes to mortality in winterkill lakes. In several Alberta lakes, yellow perch undergo a large depletion of body energy content over winter due to reduced feeding, and the energetic demands of gonadal recrudescence (Jansen and Mackay 1991; Tanasichuk and Mackay 1989). Therefore, further reductions in food intake due to low winter $\left[\mathrm{O}_{2}\right]$ may increase the severity of winterkill in yellow perch.

\subsection{Winter Oxygen Requirements of Freshwater Gamefish}

Given that a relatively low $\left[\mathrm{O}_{2}\right]$ in the range of $2-3 \mathrm{mg} \mathrm{O} / \mathrm{L}$ is probably sufficient to prevent most winterkill events, one may ask why it is necessary to define the winter oxygen requirements of fish more precisely? An accurate knowledge of winter oxygen requirements will provide at least three important benefits.

1. In many lakes, it may be possible to remedy winterkill problems simply by stocking more resistant gamefish species. This would be a vastly less expensive undertaking than alternative measures such as artificial aeration. Recall that once $\left[\mathrm{O}_{2}\right]$ falls below about $3 \mathrm{mg} \mathrm{O} / \mathrm{L}$, further oxygen depletion occurs much more slowly. Furthermore, in lakes exhibiting intermittent or marginal winterkill problems, lethal oxygen levels may persist 
for only a few days to a week before being alleviated by photosynthesis or spring melt. Therefore, even small differences in low oxygen resistance or tolerance between fish species can have a large impact on overwinter survival.

2. A knowledge of gamefish oxygen requirements can be used to substantially reduce the cost of lake aeration. Simple calculations based on $\left[\mathrm{O}_{2}\right]$ and lake volume show that even relatively small lakes contain many tons of dissolved oxygen. For example, Amisk Lake, Alberta $\left(\right.$ area $=5.15 \mathrm{~km}^{2}$, volume $=79.7 \times 10^{6} \mathrm{~m}^{3}$ ) contains approximately 797 metric tons of dissolved oxygen at fall overturn (assuming $\left[\mathrm{O}_{2}\right]=10 \mathrm{mg} / \mathrm{L}$ ). Thus, if the $\left[\mathrm{O}_{2}\right]$ deemed necessary for winterkill prevention can be reduced by even $0.5 \mathrm{mg} \mathrm{O}_{2} / \mathrm{L}$, the demands on artificial aeration would be reduced by 39.9 tons of oxygen.

3. Accurately known oxygen requirements will improve the reliability of winterkill prediction and thereby improve fish harvesting strategies. Failure to forecast winterkill events can result in a considerable loss or under-use of commercial and sport fishing opportunities. Conversely, increasing fish harvests in anticipation of a winterkill event which never materializes results in needless damage to healthy fish populations.

Three different methods have been used in previous studies to determine the minimum oxygen requirements of freshwater fish. The most common method involves placing fish in closed containers, and allowing the animal's metabolism to deplete the oxygen supply until loss of equilibrium or death occurs (Chapman 1939; Irving et al. 1939; Wilding 1939; Fry et al. 1947; Somers 1991). The oxygen concentration remaining in the container when the fish asphyxiates is purported to indicate the minimum level necessary to sustain life. However, as several authors have pointed out, fish continue to consume oxygen as they are dying (Basu 1959; Doudoroff and Shumway 1970). Therefore, the oxygen levels remaining within the containers after fish asphyxiate will considerably underestimate the oxygen levels at which lethal effects begin (i.e. the incipient lethal level; Fry 1947). The smaller the container in which fish are asphyxiated, the greater will be the degree of underestimation. In an attempt to make these experiments more rigorous, it has been postulated that the $\left[\mathrm{O}_{2}\right]$ remaining after fish are rapidly asphyxiated in closed containers represents the lowest level at which fish are able to extract oxygen from their environment. This $\left[\mathrm{O}_{2}\right]$ is termed the "minimum residual level" and is thought to indicate the point where hemoglobin becomes rapidly deoxygenated or where the nerve centres controlling gill ventilation become impaired. If this hypothesis were to be validated, then the minimum 
residual level might be justified for comparing the relative low oxygen tolerances of different fish species, or the effects of experimental treatments on such tolerances. In actual practice however, no attempt has been made to standardize the various conditions such as flask volume, rate of oxygen depletion and experimental end point (loss of balance, cessation of ventilation, lack of further oxygen uptake) which influence measurement of the minimum residual level.

A second method used to determine the oxygen requirements of fish involves lowering fish in live-boxes to various depths within a stratified lake to achieve a graded set of low oxygen exposures (Smith 1925; Moore 1942). This method has the considerable advantage of exposing fish to stable oxygen levels under natural conditions of light and water chemistry. Its major disadvantage arises from the increased activity and possible injury which fish may experience in attempting to escape from the live-boxes. Studies by Shepard (1955) clearly show that increased activity levels lower the resistance of fish to low oxygen. Moore (1942) states that fish with cuts, injuries, or fungal infections quickly succumb to oxygen tensions which are not harmful to healthy fish. If these limitations can be overcome, the live-box method could be very useful in quantifying winter oxygen requirements.

Flow-through respirometry is the third, and most useful, method used to measure oxygen requirements in freshwater fish. In this method, the respiration container (usually a large flask or aquarium) is flushed, either continuously or intermittently, with water whose $\left[\mathrm{O}_{2}\right]$ has been adjusted to the desired level. Low $\left[\mathrm{O}_{2}\right]$ in the water entering the respiration container is usually achieved by bubbling nitrogen gas through a column of water, with glass marbles sometimes being used to increase the surface area available for deoxygenation (Wilding 1939; Fry et al. 1947; Shepard 1955; Davison et al. 1959; Petrosky and Magnuson 1973). Deoxygenation has also been achieved by boiling water, or by chemically binding the oxygen (Wilding 1939). These methods are less desirable because they alter other parameters, such as bicarbonate hardness and $\mathrm{pH}$, which must then be corrected using additional procedures.

The flow-through method has several important advantages. In this method, the rate at which $\left[\mathrm{O}_{2}\right]$ is lowered can be precisely regulated to minimize fish agitation by rapid deoxygenation. A turnover of water in the respiration container also minimizes the buildup of toxins, such as ammonia and $\mathrm{CO}_{2}$, which can be a problem with the closed-vessel method. However, the most important advantage of the flow-through method is that it considerably improves the accuracy with which incipient lethal $\left[\mathrm{O}_{2}\right]$ is determined. Two factors contribute to 
improved accuracy. First, because $\left[\mathrm{O}_{2}\right]$ is experimentally regulated, the fish cannot alter water $\left[\mathrm{O}_{2}\right]$ as it is dying. Second, a constant $\left[\mathrm{O}_{2}\right]$ allows one to determine resistance time, which is simply the length of time fish can survive at any given lethal $\left[\mathrm{O}_{2}\right]$. Resistance time must be known because the incipient lethal level refers to the highest $\left[\mathrm{O}_{2}\right]$ at which a given mortality rate occurs within a specified period of time. Ideally, this time period should be long enough to allow the type of mortality being examined (e.g. acute vs chronic) to reach completion. This aspect of low oxygen tolerance has not been fully appreciated in previous studies. The study by Shepard (1955) is the only one to have accurately determined the duration over which acute mortalities occur at a given $\left[\mathrm{O}_{2}\right]$ and temperature.

Given the poor experimental design and lack of standardization which characterizes many previous studies on fish oxygen requirements, it is instructive to examine the physiological and experimental principles which should be considered in future investigations. In principle, there exists an $\left[\mathrm{O}_{2}\right]$, termed the incipient limiting level, above which physiological processes operate optimally without any limitation related to oxygen availability. This zone can be referred to as the zone of independence (Fig. 1). Oxygen concentrations below the incipient limiting level constitute the zone of dependence in which the maximum rate of a physiological process (e.g. swimming speed or oxygen consumption) becomes limited or dependent on $\left[\mathrm{O}_{2}\right]$. As $\left[\mathrm{O}_{2}\right]$ declines further, a level is reached at which maximum oxygen consumption is just sufficient to satisfy the standard metabolic rate, or the oxygen requirements associated with maintenance processes. This $\left[\mathrm{O}_{2}\right]$ has been termed the "level of no excess activity" (Fig. 1) and was once thought to be the point below which mortality from oxygen deficiency begins (i.e. the incipient lethal level). However, Shepard (1955) and Graham (1949) argue that standard metabolic rate may itself be somewhat dependent on $\left[\mathrm{O}_{2}\right]$, and that its determination at non-limiting $\left[\mathrm{O}_{2}\right]$ will be considerably above the minimum oxygen consumption required to sustain life. Oxygen concentrations below the incipient lethal level constitute the zone of resistance, wherein fish may survive for a time, but will eventually succumb (Fig. 1). As $\left[\mathrm{O}_{2}\right]$ declines below the incipient lethal level, resistance time becomes progressively shorter until it plateaus at a minimum value corresponding to the fish's resistance time in completely anoxic water. Minimum resistance time is believed to depend primarily on metabolic rate and the fish's capacity to survive on energy derived from anaerobic glycolysis. Resistance time likely reaches its minimum value when $\left[\mathrm{O}_{2}\right]$ 


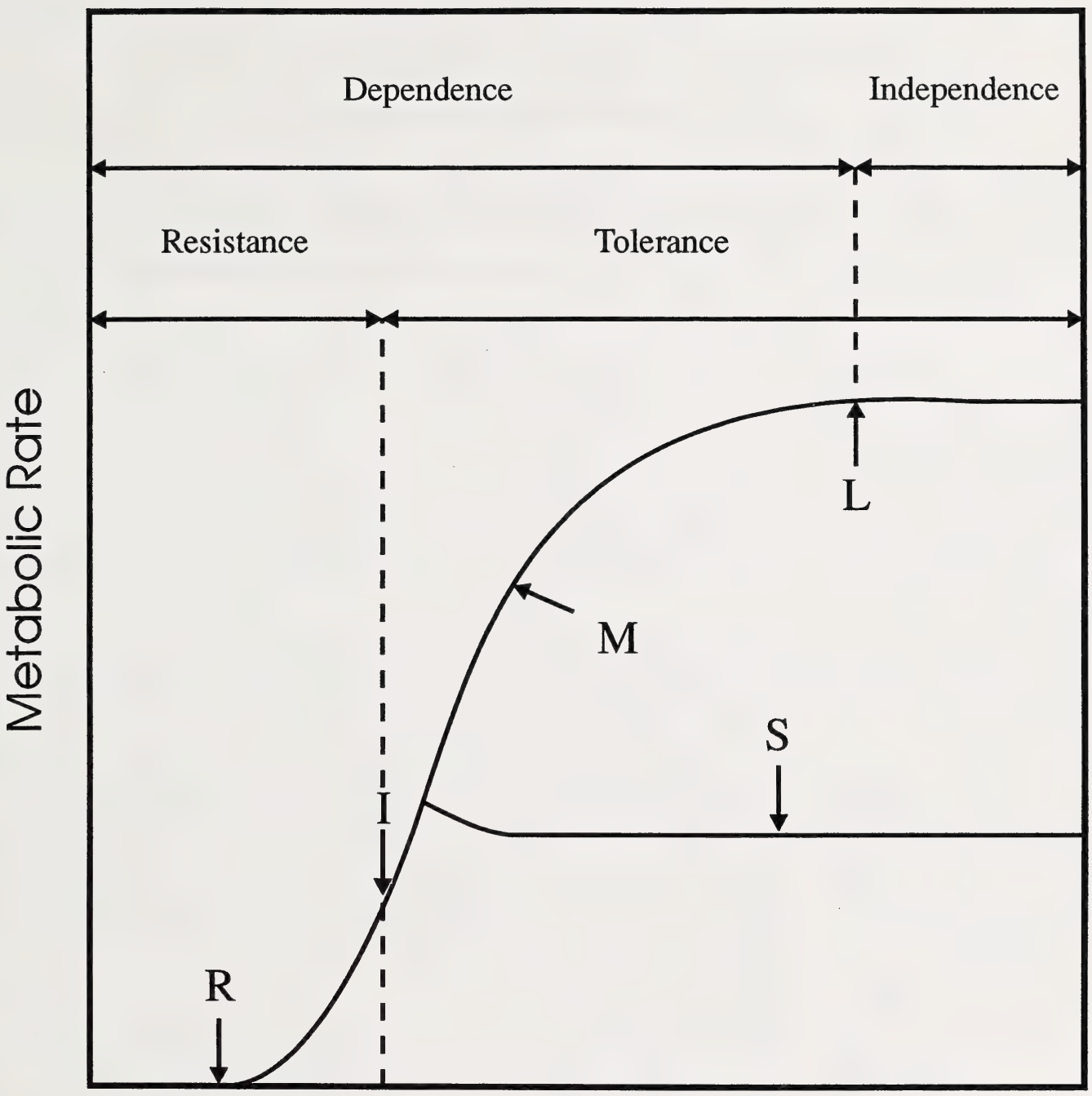

\section{Oxygen Concentration}

L - Incipient limiting level

I - Incipient lethal level

$\mathrm{R}$ - Minimum residual level

S - Standard metabolic rate

M-Maximum metabolic rate

Figure 1. Conceptual model of metabolic responses to low oxygen. Drawn after Shepard (1955). 
declines to the point at which further oxygen uptake becomes impossible; this corresponds approximately to the minimum residual level observed in closed-vessel experiments.

The principles outlined above lead to a conceptual model which can be used to describe and quantify fish mortality due to low oxygen. At extremely low oxygen levels (see Fig. 2, curve 1) all fish die shortly (within about 1 hour in trout) after imposition of hypoxic conditions. In this situation, fish are unable to adapt and die from the direct effects of low oxygen; this is commonly referred to as asphyxiation. At moderately lethal oxygen levels, mortalities begin later and fish die over a longer time period. This is reflected in a shift to the right and a decreased slope of the cumulative mortality vs. time curve (see curve 2 in Fig. 2). At moderately lethal oxygen levels, some fish may survive long enough to adapt to low oxygen and thereby avoid death from acute hypoxia. Therefore, cumulative mortality does not reach $100 \%$, but plateaus at a lower level (curve 2). Oxygen levels which have low acute lethality will produce only 10 to $20 \%$ mortality (curve 3 ) during the period in which adaptation to low oxygen occurs. At some point after acute mortalities have ceased, the secondary effects of low oxygen become expressed.

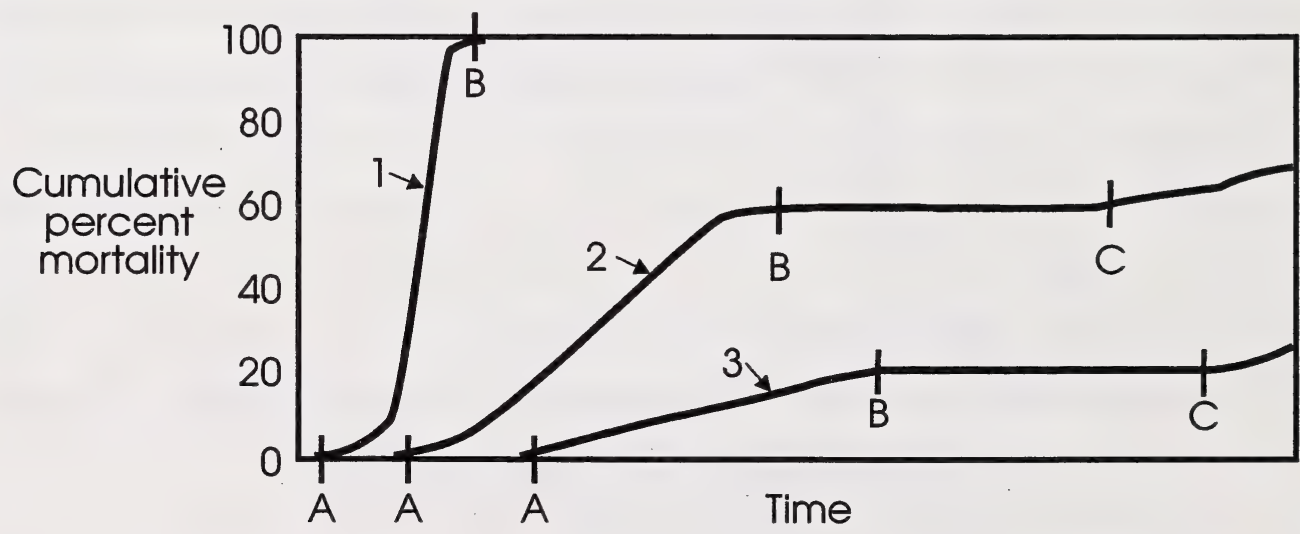

1 - Extremely lethal oxygen concentration (approx. $1.5 \mathrm{mg} / \mathrm{L}$ )

2 - Moderately lethal oxygen concentration (approx. $1.75 \mathrm{mg} / \mathrm{L}$ )

3 - Somewhat lethal oxygen concentration (approx. $2.0 \mathrm{mg} / \mathrm{L}$ )
$A$ to $B=$ period of acute lethality
$B$ to $C=$ plateau of acute mortality
right of $\mathrm{C}=$ period of chronic or secondary mortality

Figure 2. Theoretical time course of mortality at various oxygen concentrations. 
Eventually, the mortality rate increases again due to factors such as chronic stress, disease, and starvation which are secondary effects of low oxygen. This type of mortality can be termed chronic or secondary mortality, and is depicted to the right of point $\mathrm{C}$ on curves 2 and 3.

It is apparent that determining the acute oxygen requirements of fish is essentially a bioassay or toxicological problem. The most appropriate parameters with which to define low oxygen tolerance are probably median resistance time and LC50. Even more useful is the determination of oxygen concentrations resulting in 5 and $95 \%$ acute mortality. The criteria used to determine when death has occurred also needs to be considered. The ideal criterion is probably the cessation of ventilatory movements because thereafter recovery becomes impossible without alleviation of oxygen deficiency. Loss of equilibrium has also been used as the endpoint, but is a less reliable criterion. At oxygen levels near the incipient lethal level, many fish suffer a temporary loss of equilibrium and later recover their balance for a period of time (Shepard 1955).

Much of the present information on acute oxygen requirements in fish originates from the early study by Shepard (1955) who determined the median resistance times and LC50 of brook trout (Salvelinus fontinalis) at $10^{\circ} \mathrm{C}$. At that temperature, median resistance times rarely exceeded 2,000 minutes ( 33 hours) and acute mortality appeared to be complete within 5,000 minutes ( 3.5 days) (Shepard 1955). At winter temperatures $\left(<4^{\circ} \mathrm{C}\right)$, these survival times would be considerably longer (Moore 1942), but by how much is not known. The range of oxygen concentrations which produced acute mortalities from 0 to $100 \%$ in brook trout was quite narrow. At $10^{\circ} \mathrm{C}$, acute mortalities of 5,50 , and $95 \%$ occurred at oxygen concentrations of $1.9,1.75$, and $1.5 \mathrm{mg} \mathrm{O} / \mathrm{L}$ respectively (Shepard 1955). Upon acclimation to low oxygen, Shepard (1955) was able to achieve survival in brook trout with as little as $1.05 \mathrm{mg} \mathrm{O}_{2} / \mathrm{L}$ and with no more than about $5 \%$ mortality in 5,000 minutes. At $10^{\circ} \mathrm{C}$, complete acclimation of brook trout required about 70 hours for each $1.0 \mathrm{mg} \mathrm{O}_{2} / \mathrm{L}$ change in acclimation $\left[\mathrm{O}_{2}\right]$. Although acclimation to low oxygen significantly reduced the incipient lethal level, its greatest effect appeared to be on resistance time which increased approximately five fold. Acclimation produced a greater effect on resistance time at higher lethal oxygen levels and did not influence minimum resistance time (Shepard 1955). Shepard (1955) interpreted the relatively small influence of acclimation on the incipient lethal level to indicate that acclimation was probably mediated by increases in total blood hemoglobin content rather than by changes in the affinity of hemoglobin for oxygen. Berg 
and Magnuson (1970) found that wild perch taken from a Wisconsin lake having a history of winterkill had significantly lower residual oxygen concentrations (determined using closed-vessel respirometry), and slightly more blood hemoglobin content than perch from a non-winterkill lake.

In brook trout ranging in size from 0.92 to 12.1 grams, body size had no effect on the incipient lethal level (Shepard 1955). However, resistance times were markedly dependent on size; fingerlings survived approximately five times longer at lethal $\left[\mathrm{O}_{2}\right]$ than fry (Shepard 1955). This response is opposite to that observed in an actual winterkill situation where larger northern pike were less resistant to hypoxia than smaller ones (Casselman et al. 1975). Thus, the mechanisms underlying death from low oxygen appear to differ between laboratory and field situations, and may differ between fish species. Large differences in low oxygen tolerance are believed to exist between various north-temperate freshwater fish. Bullhead catfish, mudminnows, and brook sticklebacks are regarded as among the most tolerant of low oxygen (Greenbank 1945; Cooper and Washburn 1949; Nelson and Paetz 1992). Yellow perch, northern pike, rock bass, and sunfish are considered to have intermediate oxygen requirements, whereas the most oxygen sensitive fish include salmonids, whitefish, and possibly largemouth and smallmouth bass (Greenbank 1945; Cooper and Washburn 1949; Petrosky and Magnuson 1973; Nelson and Paetz 1992). Although it has not been well studied, ecologically significant differences in low oxygen tolerance may also exist among the various salmonid species. Gutsell (1929) noted with some surprise that brook trout appeared to survive longer than either brown or rainbow trout after being transferred into spring water which was naturally low in oxygen (0.94 $\mathrm{mg} \mathrm{O}_{2} / \mathrm{L}$ ). In British Columbia, brook trout are now the preferred species for stocking in winterkill lakes because they show better survival (Ashley et al. 1992). However, it is not known whether the success of brook trout results from greater tolerance of low oxygen under winter conditions or from other factors such as the ability to detect and find oxygenated water (Ashley 1992). Feldmeth and Eriksen (1978) hypothesized that Arctic grayling were more successful than cutthroat trout in colonizing certain headwater lakes in Montana because of a greater tolerance to low oxygen. Field measurements using closed-vessel respirometry failed to detect any significant differences in low oxygen tolerance between these species (Feldmeth and Eriksen 1978). Whether Arctic grayling differ from other salmonids in resistance time at lethal $\left[\mathrm{O}_{2}\right]$, or in the ability to respire surface water, has not been studied. 


\subsection{Behavioural Responses of Fish to Oxygen Gradients}

Presently it seems prohibitively expensive to artificially aerate the entire water mass of large winterkill lakes. Achieving overwinter fish survival in these lakes will likely depend on the feasibility of creating oxygenated refuges or cells in lakes and the ability of fish to find the refuge. The ability of fish to detect, and move away from, poorly oxygenated water has been confirmed in a substantial number of studies. As previously mentioned, many fish species rise toward the surface when encountering hypoxic water, both in captivity and in the wild. In lakes that experience hypolimnetic oxygen depletion in summer, all but the most oxygen tolerant species such as brown bullheads avoid the deeper hypoxic water by moving toward the surface (Fast 1973; Gebhart and Summerfelt 1976; Magnuson et al. 1979; Mosher 1983; Rudstam and Magnuson 1985). Rainbow trout have been observed to move through a hypoxic metalimnion (approximately 2 - 4 metres of water containing $<1 \mathrm{ppm}$ of oxygen) to reach surface waters (Sern 1976). When hypolimnetic hypoxia is alleviated by artificial aeration, coolwater fish such as trout quickly return to deeper waters, especially in shallow lakes wherein surface temperatures approach the fish's tolerance limits (Fast 1973; Hess 1975; Gebhart and Summerfelt 1976; Overholtz et al. 1977). In Amisk Lake, Alberta, liquid oxygen injection into the hypolimnion of the north basin significantly extended the summer depth distribution of cisco. Vertically set gill nets and echo-surveys showed that in the unaerated south basin of Amisk Lake, only 20 $30 \%$ of cisco occupied water deeper than $7 \mathrm{~m}$, whereas in the aerated north basin $60 \%$ of cisco were found at depths of 9 to $15 \mathrm{~m}$ (P. Aku, unpublished data).

Fish have also been observed to move horizontally over substantial distances to reach aerated water. From June to September of 1991, cisco density in the unaerated south basin of Amisk Lake decreased steadily from $>1,500$ to $<200 \mathrm{fish} / \mathrm{ha}$, while in the aerated north basin density increased from 2,500 to 5,000 fish/ha (P. Aku unpublished data). Cisco biomass in the two basins changed in parallel with density. These observations imply that cisco were actively moving from the south basin, where hypolimnetic $\left[\mathrm{O}_{2}\right]$ was relatively low, to the north basin. Such reciprocal changes in cisco density between the two basins were looked for in the summers of 1989 and 1990, but not observed, probably because they were obscured by a large lake-wide increase in cisco density and biomass which occurred between 1988 and 1991. Because cisco comprised $94-96 \%$ of the gill net catch in Amisk Lake, it was not possible to determine whether 
hypolimnetic aeration influenced the spatial distribution of other species such as northern pike and yellow perch.

Fish also respond strongly to oxygen gradients under winter conditions. Johnson and Moyle (1969) reported that pike in Minnesota winterkill lakes often move into stream outlets and seepage areas once $\left[\mathrm{O}_{2}\right]$ declines below $2 \mathrm{ppm}$. In the 1960's, the attraction of pike to aerated water was used to rescue or harvest them from large Minnesota winterkill lakes. Aerated water would be pumped into channels made in the ice at right angles to shore, and the aggregating pike captured within the channel using live traps (Johnson and Moyle 1969). Two such pumping stations (200,000 gallons per hour each) were used at Laura Lake (1,454 acres, max. depth 7.5 $\mathrm{ft}$ ), Minnesota. Catch rates were dependent on $\left[\mathrm{O}_{2}\right]$, and were greatest at $<1 \mathrm{ppm}$ of oxygen. The activity level of pike, as indicated by catch rate, seemed to be triggered by rapid declines in $\left[\mathrm{O}_{2}\right]$ and by water current. Accordingly, alternate starting and stopping the pumps at 24 hour intervals often attracted more pike than continuous operation (Johnson and Moyle 1969). Depending on $\left[\mathrm{O}_{2}\right]$, catch rates varied from 900 to $2,800 \mathrm{lbs} /$ day. During the winter of 1966-67, 47,120 pike weighing 42,556 lbs were collected in this manner from Laura Lake (Johnson and Moyle 1969).

Observations such as those described above suggest that the attraction of fish to small areas of oxygenated water may be the key to achieving cost-effective survival of fish in large winterkill lakes. Unfortunately, factors which influence the ability of gamefish to seek and find oxygenated water under winter conditions have not been studied. Important questions on this issue include:

1. Should artificial aeration be initiated prior to hypoxia so that fish in large lakes can learn where to find aerated water once winter oxygen depletion begins?

2. Do aggressive interactions or other density dependent behaviours limit the number of fish which can aggregate near an aeration site?

3. Will factors such as water currents, holes in the ice, or food organisms in unaerated portions of a lake attract fish away from aeration sites? 


\subsection{Summary}

Several aspects of fish physiology and behaviour have potentially profitable implications for winterkill remediation. Preliminary evidence suggests that the various salmonid gamefish species may differ considerably in their resistance to low oxygen. If this could be confirmed with additional research then the stocking of the more hypoxia resistant salmonids would be an attractive alternative to aeration for rehabilitating those lakes having moderate winterkill problems. Better quantification of winter oxygen requirements would also help reduce aeration costs by indicating the minimum degree of aeration necessary to avert winterkill. More reliable winterkill prediction would result if more consideration were given to the effects of toxins $\left(\mathrm{H}_{2} \mathrm{~S}\right.$, $\mathrm{NH}_{3}, \mathrm{CH}_{3}, \mathrm{CO}_{2}$ ) and cumulative rather than instantaneous exposure of fish to low oxygen. Finally, the apparent ease with which gamefish are attracted to oxygen refuges suggests that the creation of such refuges may be a very cost-effective technique for rehabilitating large winterkill lakes. However, factors which promote fish attraction to, and retention within, oxygen refuges needs further research.

\section{WINTERKILL REMEDIATION}

\subsection{Snow Clearing}

Dissolved oxygen levels several times normal saturation values have often been observed in ice-covered lakes having little or no snow cover (Greenbank 1945; Barica and Mathias 1979; Barica et al. 1983; Ellis and Stefan 1989, 1991a). On this basis, snow clearing appears to be an extremely effective method of raising lake oxygen levels and preventing winterkill. Early efforts at snow clearing were successful in averting fish kills (Muller 1957; Paulin 1960). Unfortunately, the unpredictability of weather and logistical factors usually prohibits snow clearing from being a practical and cost-effective technique.

The most well documented study on snow clearing was conducted in January 1982 at Rock Lake (4,250 acres) and Oak Lake (7,393 acres) in Manitoba (Barica et al. 1983). Snow was cleared from $0.7 \%$ of the area of Rock Lake and $1.7 \%$ of the area of Oak Lake. Clearing began after $20 \mathrm{~cm}$ of snow had accumulated and become hard packed. The work consequently progressed more slowly than anticipated. At Rock Lake snow clearing failed to increase $\left[\mathrm{O}_{2}\right]$ or algae biomass (chlorophyl a) under the cleared ice; small increases in $\left[\mathrm{O}_{2}\right]$ were observed at Oak 
Lake (Barica et al. 1983). From the rate of photosynthetic oxygen production observed at Rock Lake during a winter of little snow (1980/81), Barica et al. (1983) estimated that $15 \%$ of lake area would have to be maintained clear of snow during January, February, and March to prevent winterkill. This corroborates well with Paulin's (1960) study in which $20 \%$ of lake area was cleared in a successful attempt to raise dissolved oxygen levels. However, to clear snow from $15 \%$ of Rock Lake would have cost about $\$ 42,500$ in 1982 . These considerations led Barica et al. (1983) to conclude that snow clearing was not an economically viable method for averting winterkill in large lakes.

In Saskatchewan, snow clearing is not considered a reliable remediation technique but is conducted in response to public pressure (Murray Koob, personal communication). When snow clearing is done the goal is to clear $20 \%$ of lake area from a plot having the smallest possible perimeter. A small perimeter is thought to minimize the transport of phytoplankton away from the snow cleared area. Although the effectiveness of snow clearing in preventing fish mortality in Saskatchewan has not been well documented, winterkills are rarely reported in lakes which were cleared in the manner previously described (Murray Koob, personal communication).

Snow removal is clearly not a method which can be relied on for cost-effective winterkill remediation each year. The cost and manpower required to remove hard packed snow or white ice from large lakes are usually prohibitive. Nevertheless, the dramatic effect of light penetration on lake oxygen levels suggests that snow removal should be considered an effective technique which can be used occasionally when environmental conditions permit. Experience has shown that winterkills are less frequent and less severe in years of relatively brief snow cover.

The most suitable candidates for snow clearing appear to be small dugout ponds which lack electric power and lakes having only a marginal risk of winterkill. On small ponds (< about 5 acres) the cost of snow clearing is probably not prohibitive if compared with the cost of installing electrical power to operate a mechanical aerator or compressed air system. In lakes having a marginal winterkill risk, it may be possible to ensure overwinter fish survival by maintaining a snow-free ice surface for only a short period in the fall. Ellis and Stefan (1991a) estimated that Island Lake (area 42.3 acres, mean depth 1.45 metres) in Minnesota would require a snow-free period of only three weeks between ice-over and ice-out to avert winterkill. Snow clearing is usually much easier to accomplish in early fall than later in the year and delayed snowfall would greatly reduce its cost. However, successful use of this strategy requires an 
accurate knowledge of the lakes oxygen dynamics, pattern of winterkill, and potential for underice photosynthesis.

\subsection{Compressed Air Injection}

This is by far the most common method used to aerate winterkill lakes in North America. The technique involves pumping air through hoses into a lake in such a manner that a curtain or plume of bubbles rises upwards from near the bottom (Fig. 3). The pumping equipment, which may be either a blower or a rotary vane compressor, is usually located on shore inside a shed to reduce noise and preclude tampering. Blowers have the advantage of delivering higher volumes of air than compressors, but are not capable of generating as much pressure. Compressors deliver air under high pressure but in low volumes and are most useful in deeper lakes where higher air pressures are necessary to overcome the hydrostatic pressure existing in deeper water. For ease of maintenance, electrical motors are the preferred power source for blowers and compressors. Gas or diesel power are acceptable if the intent is to aerate for short periods (e.g. during fall overturn) or when electrical power is unavailable and the fishery is valuable enough to justify the added expense and maintenance of these power sources.

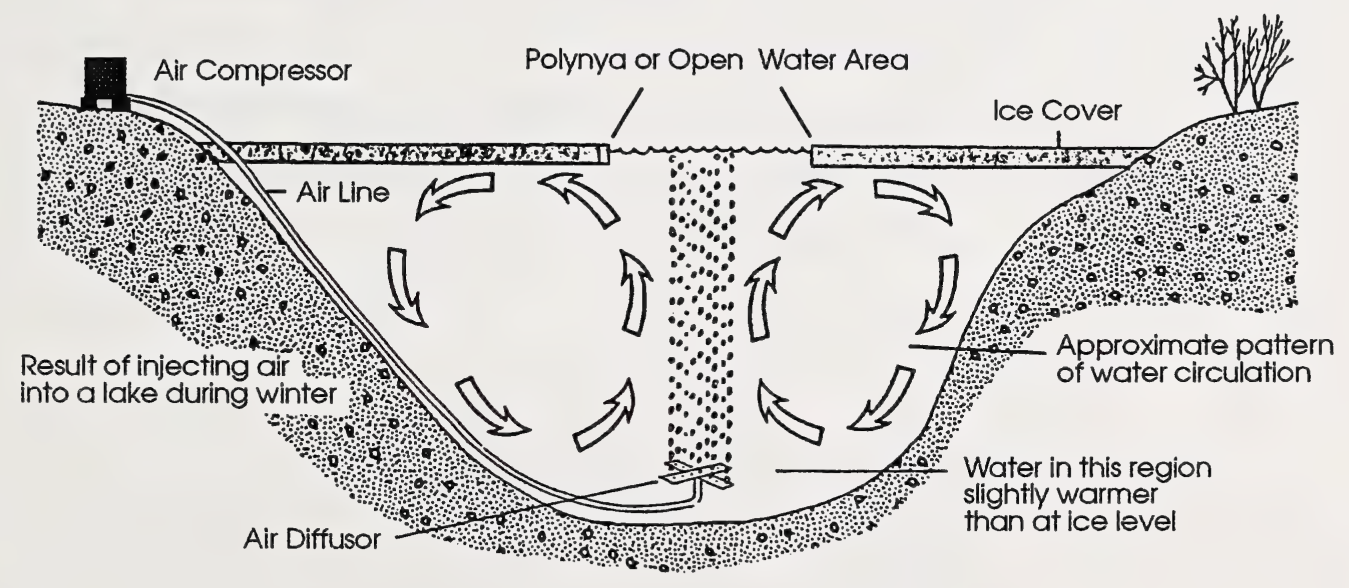

Figure 3. Compressed air lake aeration system. From Alberta Habitat Development Fact Sheet No. 4. 
Several mechanisms exist for releasing compressed air into the lake. Air released from a diffusor at the end of the hose is termed a point release and creates a plume of rising bubbles. The most common type of point release is a cross-pipe diffusor consisting of perforated metal or plastic tubing arranged in the form of an $\mathrm{X}$. Perforations in cross-pipe diffusors range in size from about 1.6 to 6.4 millimetres (1/16 to $1 / 4$ inches). Smaller bubble sizes may be achieved with diffusors made of porous stone which are designed for use in aerating sewage lagoons (U.S. E.P.A 1989). Such fine pore diffusors are seldom used to aerate winterkill lakes because they are more expensive, require higher air pressures, and are prone to clogging which is a particularly inconvenient problem to deal with in ice covered lakes (Speece et al. 1973b; Torrest 1976).

Fine bubble aeration tubing is another method used to obtain small bubble size. This tubing has very fine slits along its length which release air so as to create a longitudinal "bubble curtain". Fine bubble aeration tubing was originally designed for aeration of sewage lagoons and its primary advantage was purported to be increased oxygen transfer efficiency with a concomitant decrease in required blower capacity. However, problems with an early version of fine bubble aeration tubing (Air Aqua tubing) prompted Alberta Environment, Municipal Branch to re-evaluate its suitability for use in provincial sewage lagoons (Reid Crowther \& Partners Ltd. 1992). Air Aqua tubing was reported to be susceptible to degradation by U.V. light, prone to clogging, and tended to become waterlogged during power outages (Reid Crowther \& Partners Ltd. 1992). Maintenance operations required to avoid clogging and waterlogging involve manually "roller flexing" the tubing and flushing the tubing with hydrochloric or muriatic acid to dissolve material clogging the slits. The acid cleaning procedure is reported to be very difficult to perform under winter conditions, and concern over a possible occupational health and safety risk has been expressed (Reid Crowther \& Partners Ltd. 1992). Recently, a new type of fine bubble aeration tubing (ADS) has been developed which incorporates several new features designed to reduce problems with U.V. induced deterioration, clogging, waterlogging, and to facilitate tube cleaning. Nevertheless, the ADS tubing still requires cleaning with acid, and it is recommended that lagoon bottoms be level to within 6" to avoid waterlogging (Reid Crowther \& Partners Ltd. 1992). Aside from maintenance requirements, the major drawback of fine bubble aeration tubing for use in winter lake aeration may be the small area of open water created. The tubing appears to increase oxygen transfer from bubbles at the expense of reducing atmospheric aeration across an open water surface. Until the relative importance of oxygen absorption from 
bubbles versus open water becomes better defined (see discussion below), the choice of point release versus diffuser tubing will depend on operator experience.

Water flow patterns induced by bubble curtains or plumes have received little study under in-lake conditions but have been modeled in the laboratory. Under laboratory conditions rising bubbles create a "near field" circulation cell characterized by a surface flow of water away from the bubble plume and a bottom flow of water toward the plume (Fig. 4). Depending on the geometry of the experimental basin, the near field cell extends outward from the plume to a distance of 4 to 8 times the water depth (Hogan et al. 1970; Torrest 1976). Downward flowing water at the periphery of the near field creates a more slowly moving secondary circulation cell in the "far field". As expected, oxygen accumulation is more rapid in the near field than the far field and is accelerated by higher air flow rates (Torrest 1976).

Density stratification alters the flow pattern induced by experimental bubble plumes (Kranenburg 1979). Under stratified conditions the near field circulation cell was limited to the epilimnion due to forces which resist mixing of hypolimnetic and epilimnetic water (Fig. 4). A portion of the water flowing downward at the edge of the near field is deflected horizontally and spreads out radially as an interlayer between the epilimnion and hypolimnion. This interlayer gradually thickens until the entire water column in the far field has been destratified. In Kranenburg's (1979) study the radius of the near field gradually increased as destratification proceeded. The extent to which water flows induced by bubble plumes in lakes resemble those in small scale laboratory basins is unknown (Graham 1980). It seems likely that wind, ice cover, natural water currents, topography, and the coriolis effect will significantly affect the induced water flows (Kranenburg 1979).

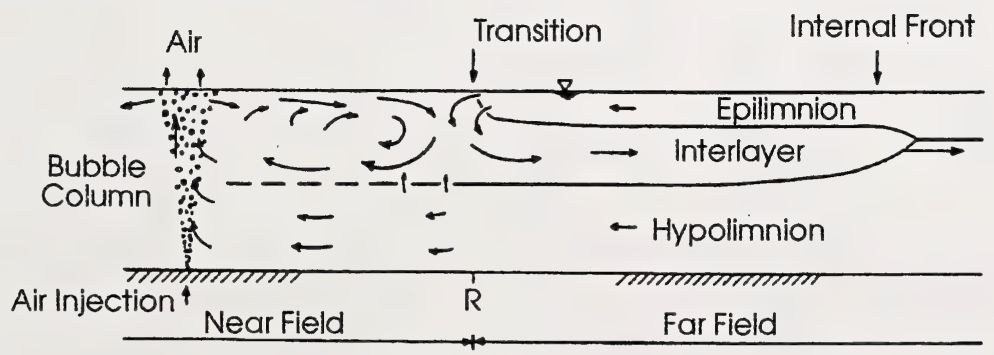

Figure 4. Kranenburg's (1979) model of water circulation patterns induced by a bubble plume in a vertically stratified lake. Note the near field circulation cell in which water circulates relatively rapidly and the far field circulation pattern which develops more slowly. 
Laboratory studies show that the vertical velocity of water within the plume decreases with height above the diffusor (Fig. 5; Speece et al. 1973a; Torrest 1976). However, because the plume spreads as it rises (Fig. 5), total water flow increases with height (Speece et al. 1973a; Torrest 1976). Water velocity within the plume decreases as bubbles become smaller (Speece et al. 1973a). As bubbles rise within the plume they change in size because of the reduction in hydrostatic pressure, oxygen exit from the bubble, and the diffusion of nitrogen and carbon dioxide into the bubbles (Speece et al. 1973b). The influence of bubble size on oxygen transfer efficiency is still somewhat uncertain. Larger bubbles rise faster which creates more turbulence at the bubble-water interface and thereby enhances oxygen transfer. Smaller bubbles do not create as much turbulence, but possess greater surface area per unit volume and have longer contact times in the aerator. The fine diffusor orifices necessary to create very small bubbles are also more prone to clogging. Speece (1974) and Ashley (1985) recommend a bubble size of 2.0 $2.5 \mathrm{~mm}$ diameter as a workable compromise.

In experimental bubble plumes, surface water velocity increases with air flow rate but the effect appears to be much less than proportional (Speece et al. 1973a; Torrest 1976). Studies by Richey and Sollitt (1970) and Kranenburg (1979) show that the efficiency of water mixing decreases with increasing air flow rate apparently because of the formation of strong circulation cells which expend energy within themselves and at the surface rather than in mixing efficiently with the surrounding fluids. Therefore, more effective lake aeration likely can be achieved from the same air flow rate if several smaller aeration sites are used rather than one large one. 

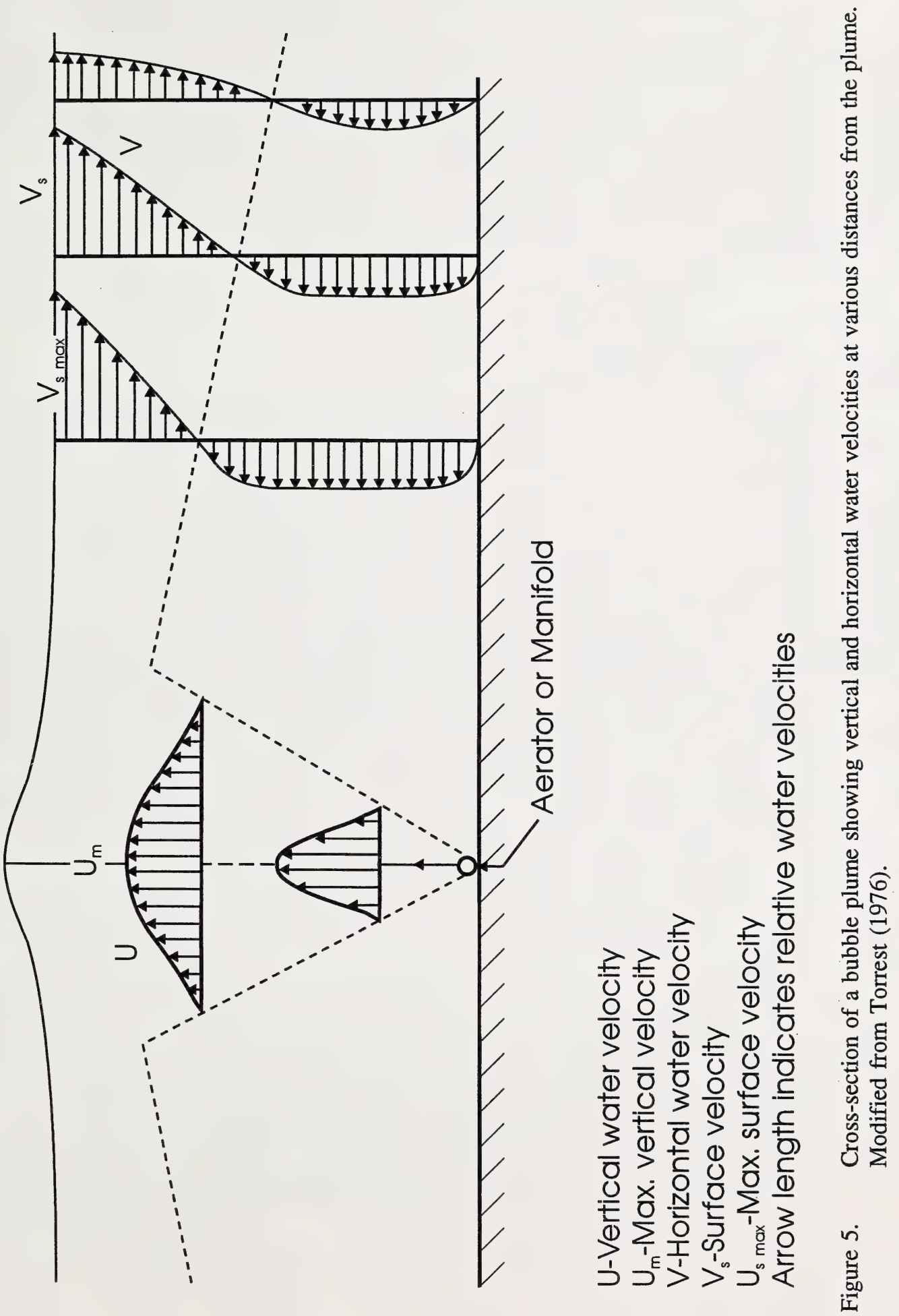
There is considerable uncertainty about whether the primary factor contributing to lake aeration by bubble plumes is the mass transfer of oxygen from the rising bubbles or natural aeration at the lake surface. A modeling study by Neilson (1974) suggested that in a reservoir $10 \mathrm{~m}$ deep and $150 \mathrm{~m}$ wide with a line diffusor down the axis, the rise and bursting of bubbles $(0.5 \mathrm{~cm}$ in diameter) could account for only about $6 \%$ of total aeration, the rest being due to aeration at the surface. In a 20 acre lake receiving 27.5 SCFM airflow released from a depth of 26 feet, the surface area of rising bubbles ( 0.8 inches in dia.) is estimated to be only $0.14 \%$ of lake surface area (Smith et al. 1975). These results suggest that the area of ice-free surface created by a bubble plume in an otherwise ice-covered lake is a critical determinant of the amount of lake aeration that occurs.

In the past, devices known as helixors were often used in efforts to increase the oxygen transfer efficiency of compressed air aeration. Helixors are plastic or metal cylinders containing a helical partition which makes one turn every two or three feet (Wirth 1970). The helical partition causes bubbles to follow a spiral path toward the surface which is thought to prolong bubble-water contact and thereby increase oxygen transfer efficiency (Wirth 1970). However, in practice, bubbles probably coalescence more readily inside the helixor and may aggregate in one portion of the spiral passageway. Furthermore, confining a bubble plume inside a cylinder may reduce its ability to entrain water. Wirth et al. (1969) measured oxygen levels along the length of a 12.2 metre helixor and found that nearly all the oxygen transfer occurred in the lower half. Increasing helixor length beyond that which results in fully oxygenated water is pointless. A beneficial effect of helixors on oxygen transfer appears never to have been documented in the literature and has not been apparent to those operating helixors in the field. Therefore, until experimental evidence indicates otherwise, helixors should be regarded as an unnecessary expense. 


\subsection{Mechanical Surface Aeration}

These aerators consist of an electric motor-propeller combination which sprays water several metres into the air in an umbrella shaped pattern (Fig. 6; Plate 1). The motor and propeller are suspended by means of floats below the lake surface. An electrical cable supplying power to the motor runs along the lake bottom to a breaker panel on shore. If it is considered necessary to draw water up from greater depths, a draught tube can be easily fitted around the propeller. These systems aerate lake water by means of the spray and also by creating a circular area of open water similar to that formed by bubble plumes.

In British Columbia, mechanical surface aerators have given such good performance that they are rapidly replacing existing compressed air systems (Ken Ashley, Brian Chan, personal communication). Mechanical surface aerators reportedly prevent winterkill with only one third $(1 / 3)$ the horsepower previously required using compressed air systems; thus yearly operating costs are much lower. Initial costs may also be lower with mechanical aerators because they do not require construction of concrete foundations or compressor sheds. Finally, mechanical aerators apparently require very little maintenance (Ashley 1987). One does not have to check oil level with mechanical aerators since they are water lubricated. Unlike air compressors, mechanical aerators never experience temperatures lower than $0^{\circ} \mathrm{C}$ (because they are immersed) and therefore appear much less susceptible to breakdown.

Experiences with mechanical surface aerators in British Columbia indicates that severely cold weather will not hinder their performance. Air temperatures of $-30^{\circ} \mathrm{C}$ cause ice to form on the floats and spray deflector, but this ice soon melts because it causes the unit to sink slightly in the water. Very strong, prolonged, and cold winds could conceivably disrupt the operation of surface spray units, but this can only be ascertained with in-lake trials.

Although mechanical surface aerators are considered superior to compressed air systems in British Columbia, a survey of lake aeration methods in Wisconsin yielded the opposite conclusion (Wirth 1988). In 1986 mechanical surface aerators were used on six winterkill lakes in Wisconsin which ranged in size from 11 to 1,026 acres. Performance as measured by $\left[\mathrm{O}_{2}\right]$, the amount of ice-free lake area, and overwinter fish survival was poorer for the mechanical spray aerators than for compressed air systems (Wirth 1988). 


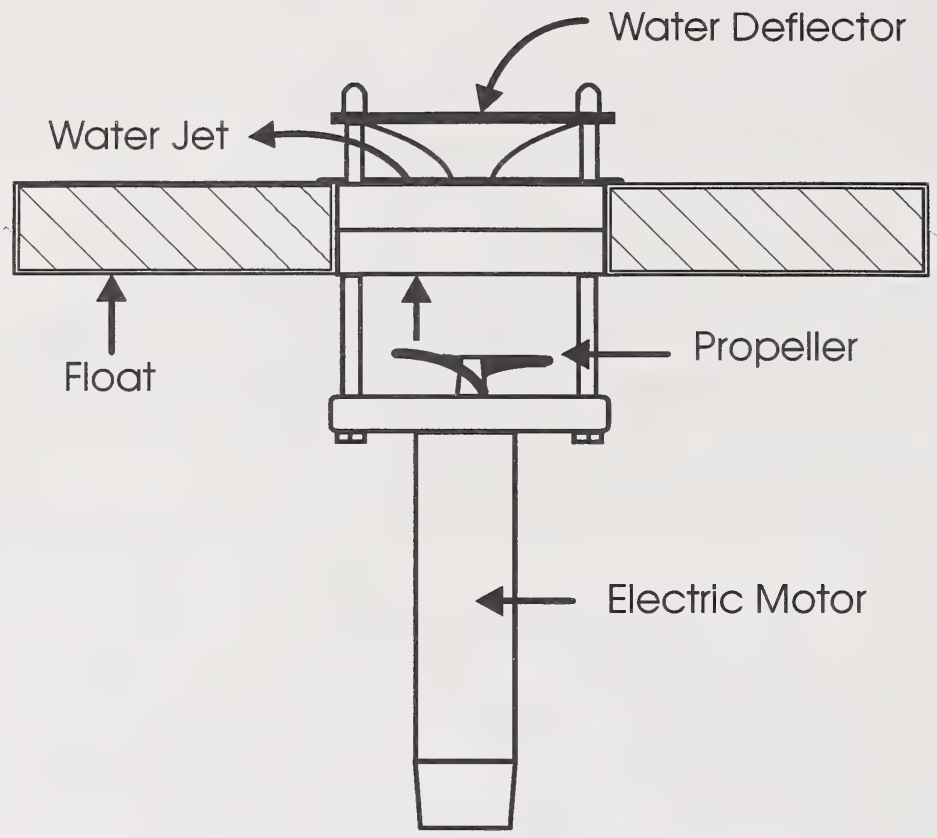

Figure 6. Mechanical surface aerator, Air-o-later ${ }^{\circledR}$ design.

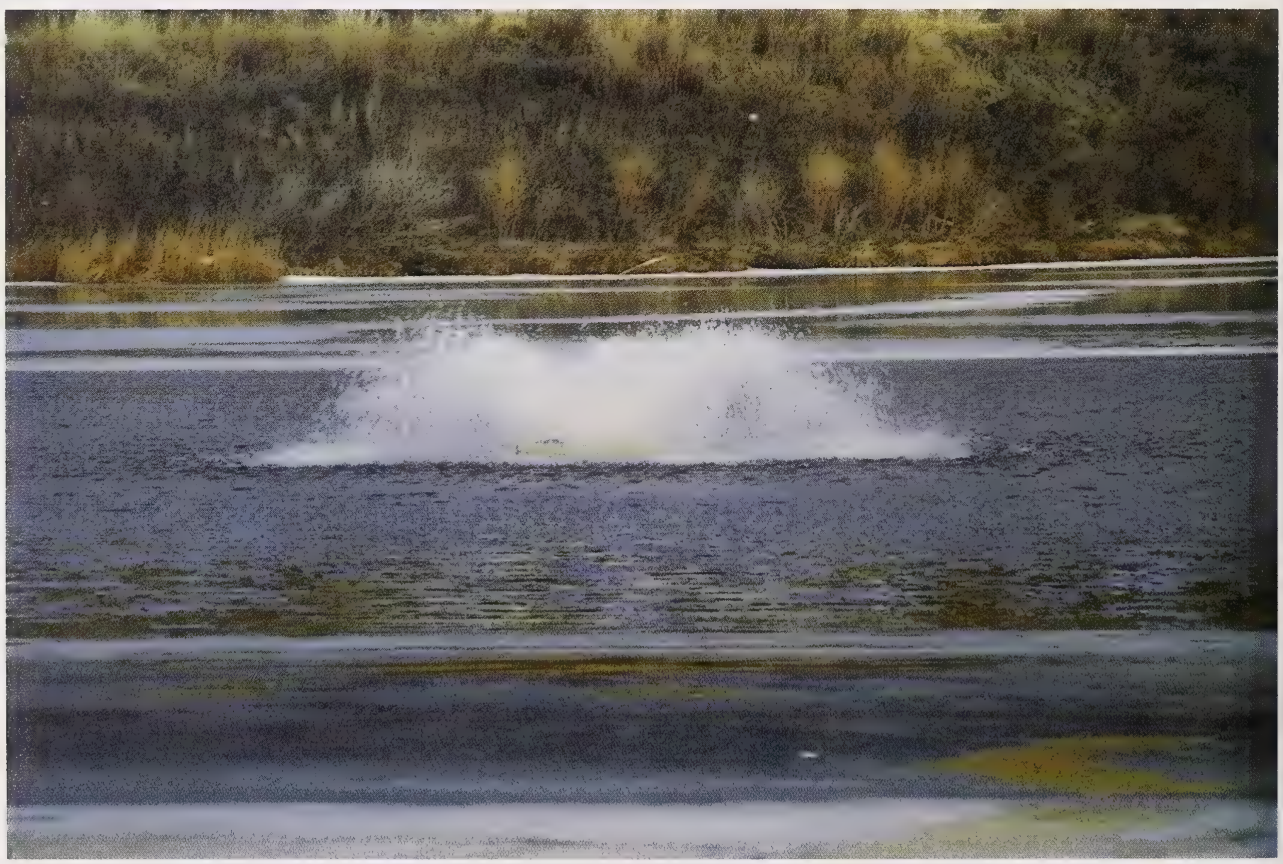

Plate 1. Mechanical surface aerator in operation in late February, 1994 at Logan Lake, British Columbia. 
The markedly different performance of mechanical aerators in British Columbia and Wisconsin is difficult to reconcile but several explanations appear plausible. First, the three largest Wisconsin lakes receiving mechanical aeration appear to have undersized systems. In those lakes mechanical aeration supplied an average of $0.0085 \mathrm{hp} /$ acre which compares with values of $0.037-0.071 \mathrm{hp} /$ acre for the better compressed air systems. Thus, mechanical aerators supplied one eighth to one quarter the power of compressed air systems and were therefore undersized according to British Columbia standards. Secondly, mechanical surface aeration may be less effective for the bass, sunfish, and crappies found in Wisconsin lakes than for salmonid species stocked in British Columbia winterkill lakes. Centrarchid fish species tend to be territorial and stay close to cover provided by rooted plants and logs. Because of their affinity for cover, centrarchids may be much more difficult to attract to aeration sites than salmonids which roam freely over large areas.

\subsection{Pump and Cascade Aeration}

Pump and cascade aeration is a form of sidestream pumping in which deoxygenated water is pumped out of the lake, aerated, and then returned to the lake. Aeration occurs in an inclined flume or chute containing numerous baffles over which lake water cascades in a turbulent flow (Fig. 7; Plate 2). Additional aeration occurs in the plunge pool created as water re-enters the lake (Plate 2). Heat lamps are sometimes installed at the aeration chute entrance to prevent spray from freezing and obstructing water flow during periods of very cold weather (Bill Howard, personal communication). To minimize water recycling, the intake pipe and aeration chute are placed as far apart as possible and the stream of aerated water is directed away from the inlet (Wirth 1988). A peninsula appears to be the ideal location for these aeration systems. If the aeration chute is placed on the lake ice, an extension is required to prevent plunging water from eroding ice directly under the chute itself.

Although the operating characteristics of pump and cascade aeration have never been described, practical experience suggests that this system has several important advantages over other methods of winter lake aeration. Unlike most other aeration systems, the pump and cascade can be easily installed after ice formation and is therefore suitable as a portable or emergency aeration method. Portable systems greatly minimize the cost of aerating those lakes which only winterkill at intervals and do not require permanent aeration systems. 
(a)

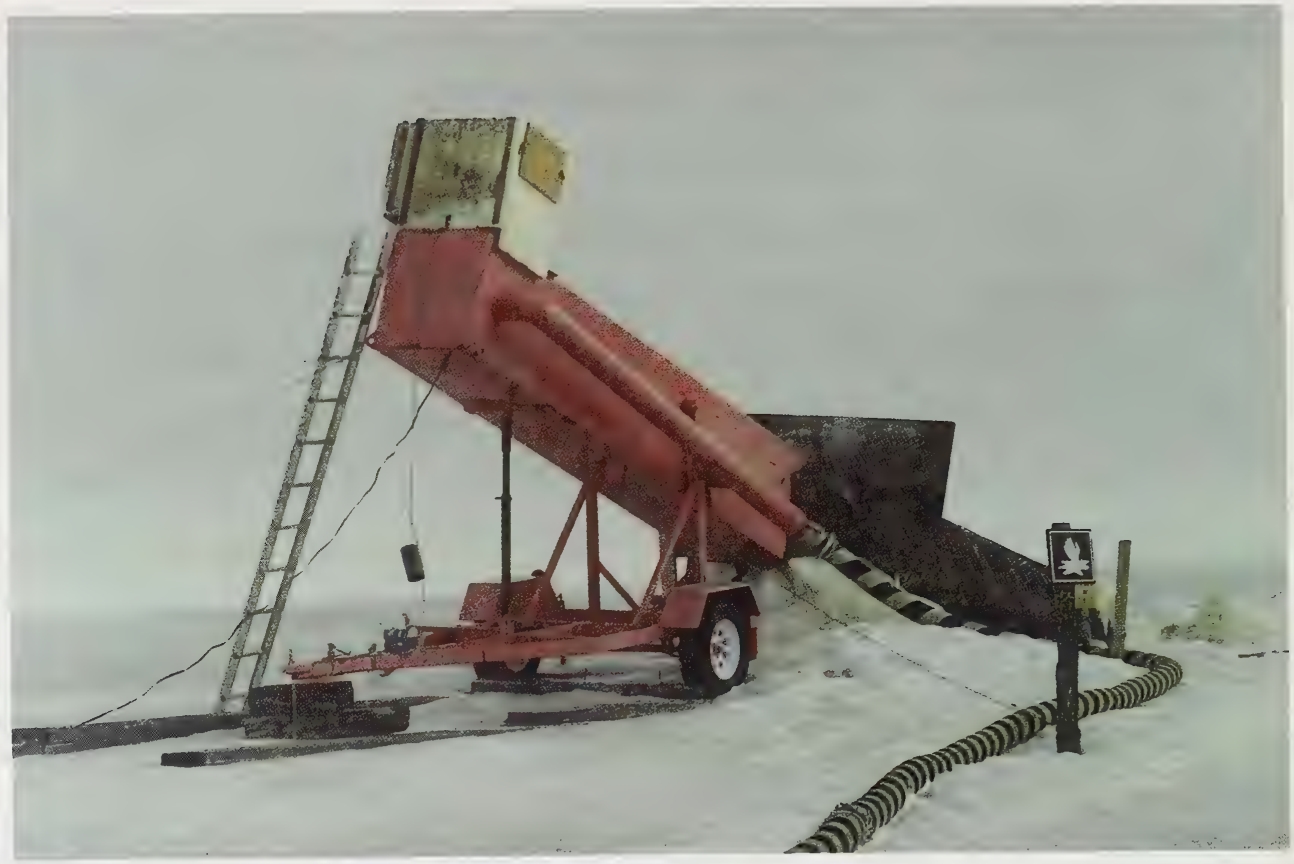

(b)

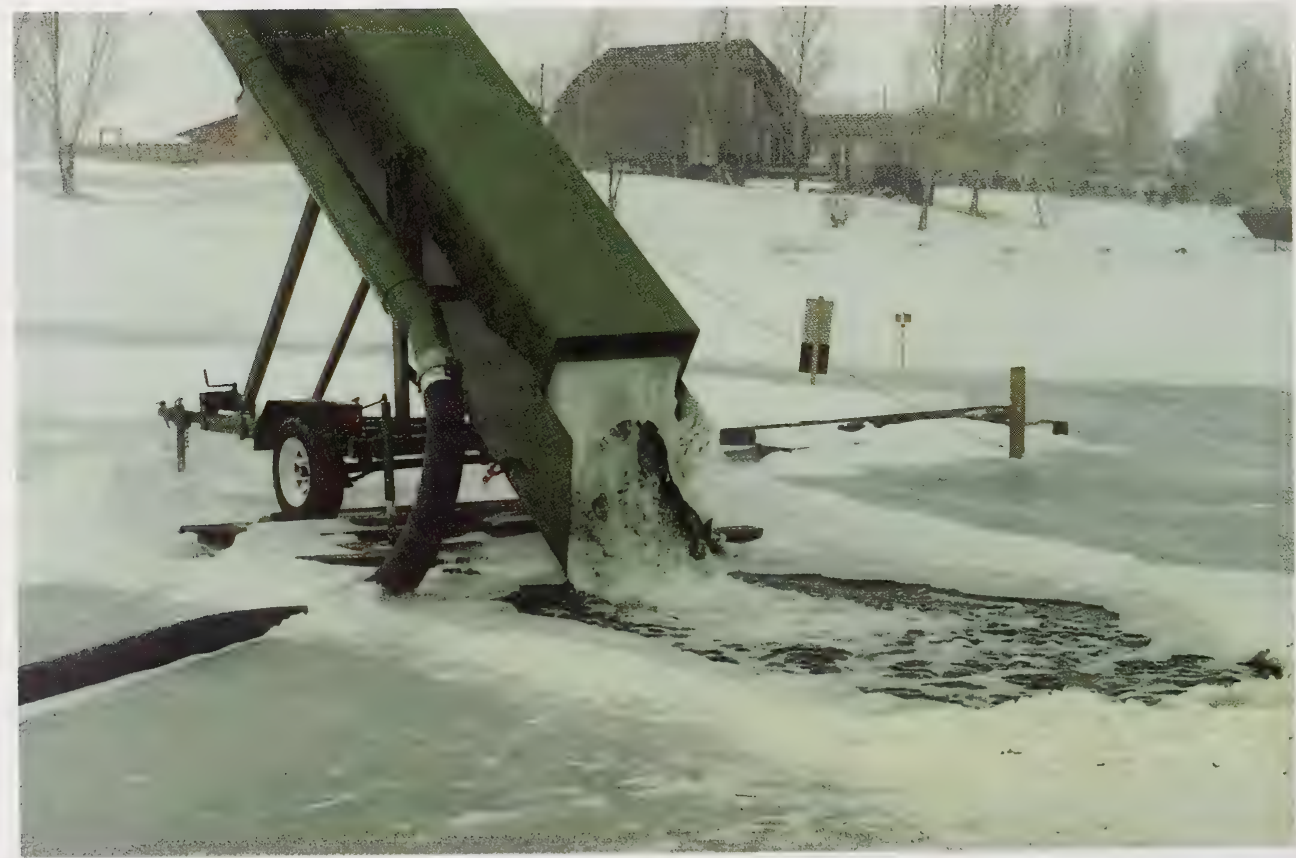

Plate 2. Pump and cascade aerators used at Oak Lake (a) and Sandy Lake (b), Manitoba, late February, 1994. 


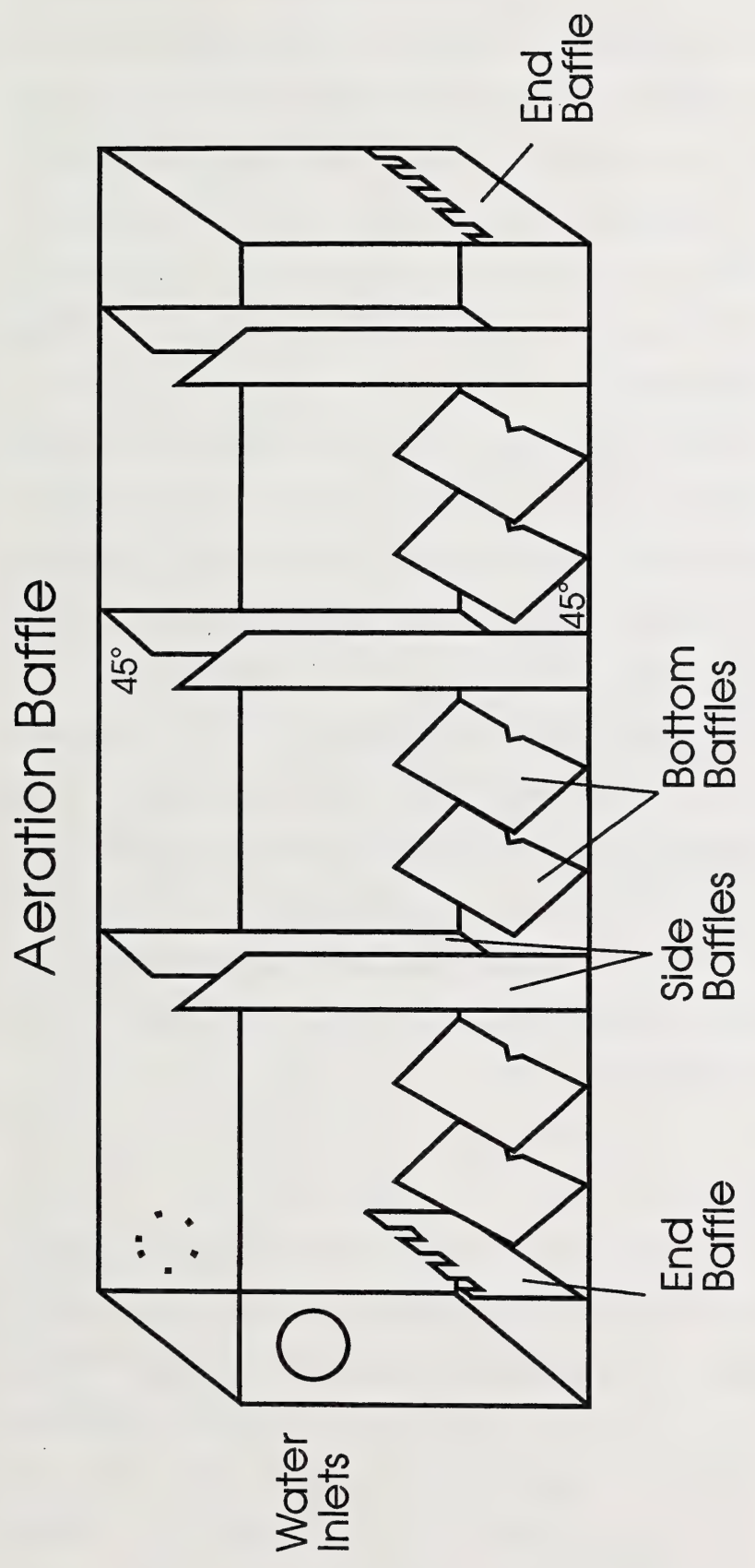

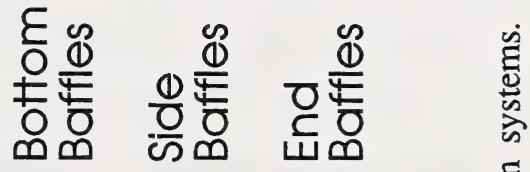

$\frac{d}{0} \quad \frac{\Phi}{0} \quad=\frac{1}{0} \quad \frac{z}{0}$

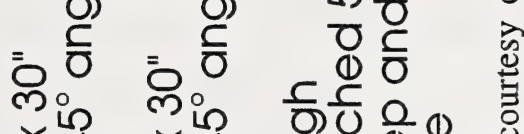
$\times y \times \frac{1}{=} \times \frac{0}{0} \frac{0}{0}$

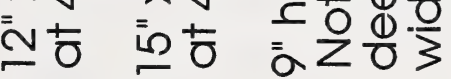

趂

율

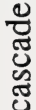

믈

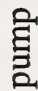

.$\Xi$

త్ర

$\underset{x}{i o}$

ต

is 
Pump and cascade systems appear to be the most economical method for aerating large winterkill lakes. In Manitoba, pump and cascade systems have been used successfully to prevent winterkill in lakes 6,000 to 7,000 acres in size (Bill Howard, personal communication). Compressed air systems were found to be unsuitable for these lakes. The advantage of pump and cascade systems is believed to be the creation of a directed flow of oxygenated water together with higher water velocities compared to other systems. These characteristics are believed to facilitate the creation of localized areas of oxygenated water which are able to attract fish from long distances. It is thought that mechanical surface spray and compressed air systems may be less suitable for large lakes because they disperse oxygenated water radially and thus create correspondingly weaker oxygen and current gradients.

Another advantage of pump and cascade systems is that they can be operated without creating large potentially dangerous areas of open water. Lake water is normally cooled as it flows through the aeration chute and this greatly reduces its ability to erode ice. In Manitoba the only area of open water created by pump and cascade systems is the plunge pool which has a size of approximately $5 \mathrm{~m}^{2}$.

Fast (1994) suggests that because pump and cascade systems do not rely on a large open water area for aeration, their efficiency may be independent of the lake's heat reserve. If this could be confirmed, pump and cascade aeration would seem ideal for aerating very shallow lakes having thick ice cover and correspondingly small heat reserves. Finally, it may be possible to modify pump and cascade systems in such a way that vertical water mixing is avoided. Such modifications hold promise for minimizing the increased sediment oxygen consumption which usually accompanies artificial aeration (see below).

\subsection{Ice-preserving/Non-mixing Aeration}

Thin ice and open water created by winter lake aeration systems pose a potentially dangerous situation to unwary recreationists which might include ice fishermen, snowmobilers, skiers, and ice skaters. Although warning devices and common sense will protect all but the most determined risk-taker, the legal liability and negative publicity arising from an accidental drowning continues to generate concern. At some lakes, snowmobilers have been seen hydroplaning their machines at high speed across the open water of an aeration site. Perhaps nowhere is concern over unsafe ice greater than in southern Minnesota where at least six deaths 
have occurred at lake aeration sites (Danks 1992). In Minnesota, 200 to 300 lakes are artificially aerated each winter. Many of these lakes are in or near large population centres and are therefore much in demand for recreational use.

To minimize the risks associated with winter lake aeration the Minnesota Legislature commissioned the development of an aeration system which would not erode the ice cover. The system developed operates on the same principle as pump and cascade aeration; lake water is removed from a certain depth, aerated, and then reinserted at the same depth. Specially designed intake and exhaust manifolds minimize turbulence and vertical mixing to avoid bringing warm bottom water in contact with lake ice (Ellis and Stefan 1990). The intent of the system is to create a laminar flow of aerated water at an intermediate depth (Fig. 8). The result would be a thin layer of aerated water which is isolated from both the ice cover and the sediment surface. Such an aeration method not only preserves the ice cover but has an important additional advantage, that of minimizing water and oxygen flow to the sediments. It appears to be the best system yet designed for minimizing the amount of oxygen consumption induced by aeration. If the design proves successful it will greatly reduce the oxygen supply rate required for effective aeration and thereby improve the cost-effectiveness of lake aeration.

The ice-preserving manifold operates on these principles. Water velocities at the manifold intake and exhaust must be very low to avoid disrupting the weak vertical density stratification which exists in winter. Achieving sufficiently low water velocities requires a long manifold with large entry and exit areas. The manifold design consists of two parallel pipes, of which one serves as the inflow, and the other as the outflow (Fig. 9). Each pipe contains two parallel rows of orifices. Rigid sheets above and below the manifolds serve as diffusers which help straighten water flow. Incoming and outgoing water flows impact on sills which dissipate energy and dampen water velocity (Fig. 9). The final component of the design, a honeycomb flow straightener, suppresses exhaust turbulence and is essential for proper operation (Fig. 9). Discharge velocities are designed to be $1.4 \mathrm{~cm} / \mathrm{s}$ or less. An axisymmetric manifold/diffuser which disperses aerated water radially instead of unidirectionally has also been designed (Ellis and Stefan 1991b). 
(a)

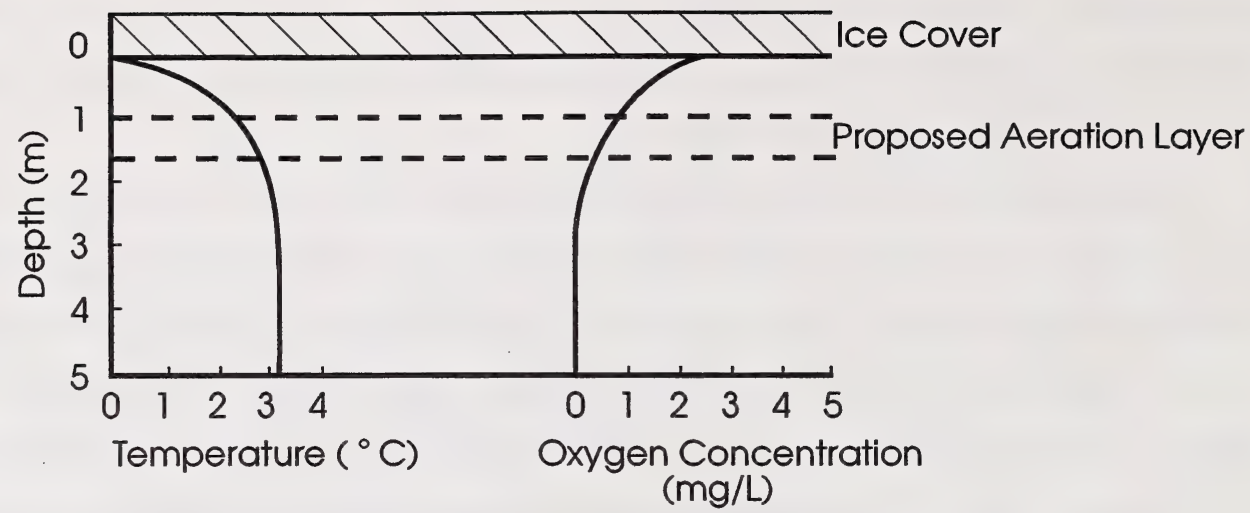

(b)

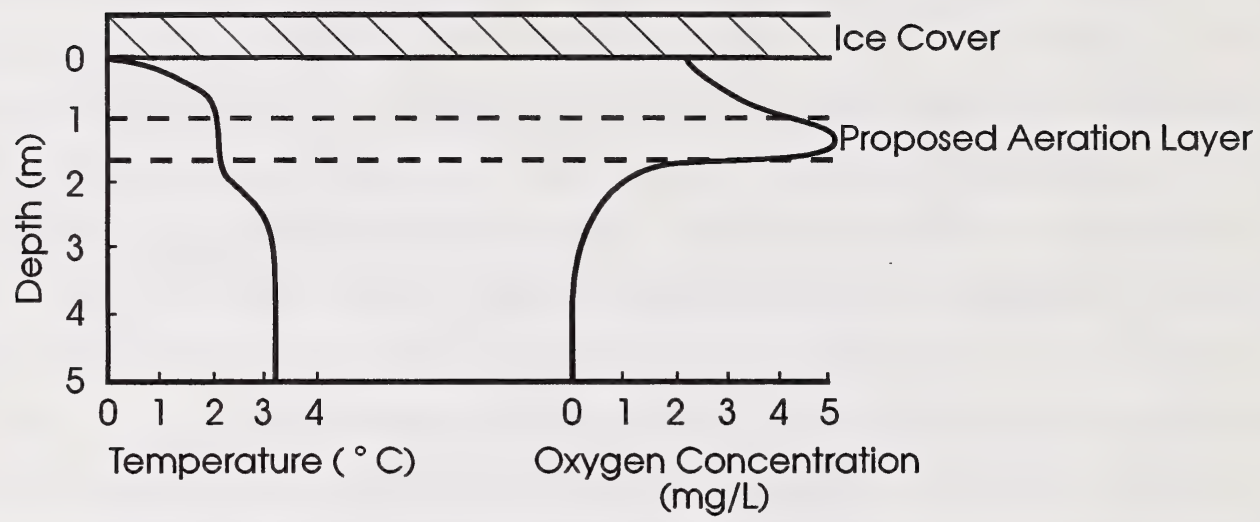

Figure 8. Idealized model of the ice-preserving aeration method of Ellis and Stefan (1990). A laminar flow diffuser (shown in Fig. 9) placed approximately $1.5 \mathrm{~m}$ below the ice cover would aerate a horizontal layer of water approximately $1 \mathrm{~m}$ thick. This aeration method would minimize vertical water mixing and thereby prevent erosion of the ice cover and reduce oxygen consumption by lake sediments. Diagrams a) and b) show oxygen and temperature profiles before and after aeration and were taken from Ellis and Stefan (1990).

The adjacent placement of intake and exhaust manifolds assumes that the aeration method does not change the temperature of the transported water. However, water aerated above the lake in winter will almost certainly cool. If necessary, this problem is easily rectified by separating the intake and exhaust manifolds and placing the exhaust manifold at a depth appropriate for the temperature of the aerated water.

Field tests of the manifold/diffuser were conducted over two winters at Island Lake, Minnesota (Ellis and Stefan 1991a). The lake has a surface area of 17.1 hectares, maximum and mean depths of 2.8 and 1.45 metres respectively, and lacks surface inflows and outflows in winter. The exhaust manifold/diffuser was placed 0.9 metres below the ice at a distance of about 765 feet from the intake manifold. An aeration chute similar to that used in pump and cascade 
systems was used to aerate lake water without changing its temperature. Both winters of the study were considerably warmer than normal which probably made for a more reliable test of the system's ability to preserve ice cover. Temperature and oxygen profiles together with dye studies showed that the system performed as expected; aerated water dispersed as a $1.5 \mathrm{~m}$ thick layer which did not mix the water column either close to or far away from the exhaust manifold. One week after injection the dye plume was still confined to a portion of the water column at a distance of over $300 \mathrm{~m}$ from the exhaust manifold. A small hole in the ice did form above the downstream end of the exhaust manifold. However, this was due to unexpected entrainment of air bubbles into the outflowing water from the aeration chute and can be easily remedied. Over most of the diffusers length the ice thickness showed no signs of degradation.

It may be of interest that the above manifold/diffuser design is entirely in the public domain and not covered by any patents (C. Ellis, personal communication). This ice-preserving aeration system does require careful initial planning and some routine maintenance because the intake manifold requires a filter screen which must be cleaned regularly. However, these will be minor limitations if the system proves to be successful in preserving ice cover and reducing oxygen and power requirements.

\subsection{Downflow Bubble Contact Aeration}

Downflow bubble contact aeration (DBCA) is an innovative method for adding oxygen to water developed by R.E. Speece (Speece et al. 1971). In DBCA a downward flow of water directed against a rising plume of bubbles is used to maximize oxygen transfer efficiency. Although several equipment configurations are possible (Fast and Lorenzen 1976), the most efficient DBCA design involves a large cone (known as a Speece cone after its originator) which is placed wide end down in the water column (Fig. 10). Lake water is pumped mechanically into the top of the cone which also receives a continual input of air or oxygen. As water flows down the cone its velocity declines because of an increase in the cone's cross-sectional area. Cone shape is designed so that the buoyant velocity of the bubbles is intermediate between that of water in the inlet and outlet (Speece et al. 1971). In this way bubbles can be held within the cone until they completely dissolve. Water must enter the cone with enough velocity to prevent bubbles from coalescing and escaping out the inlet. 


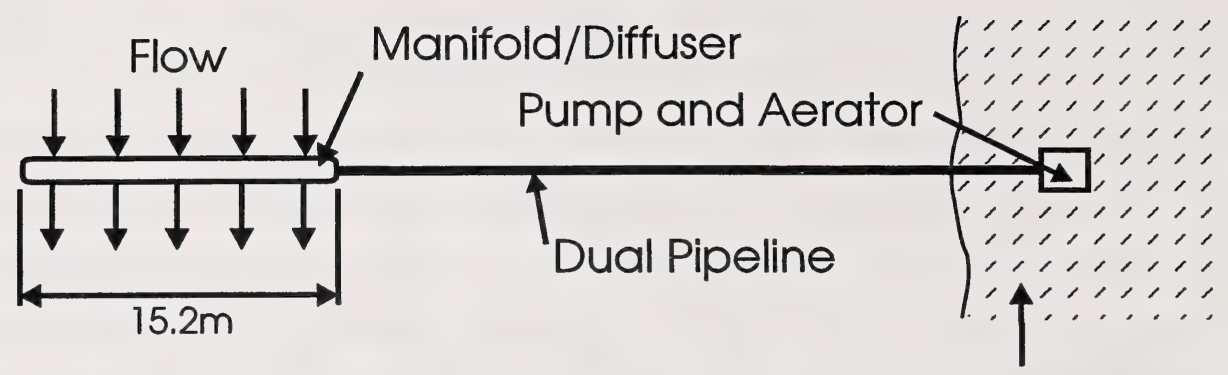

Shore

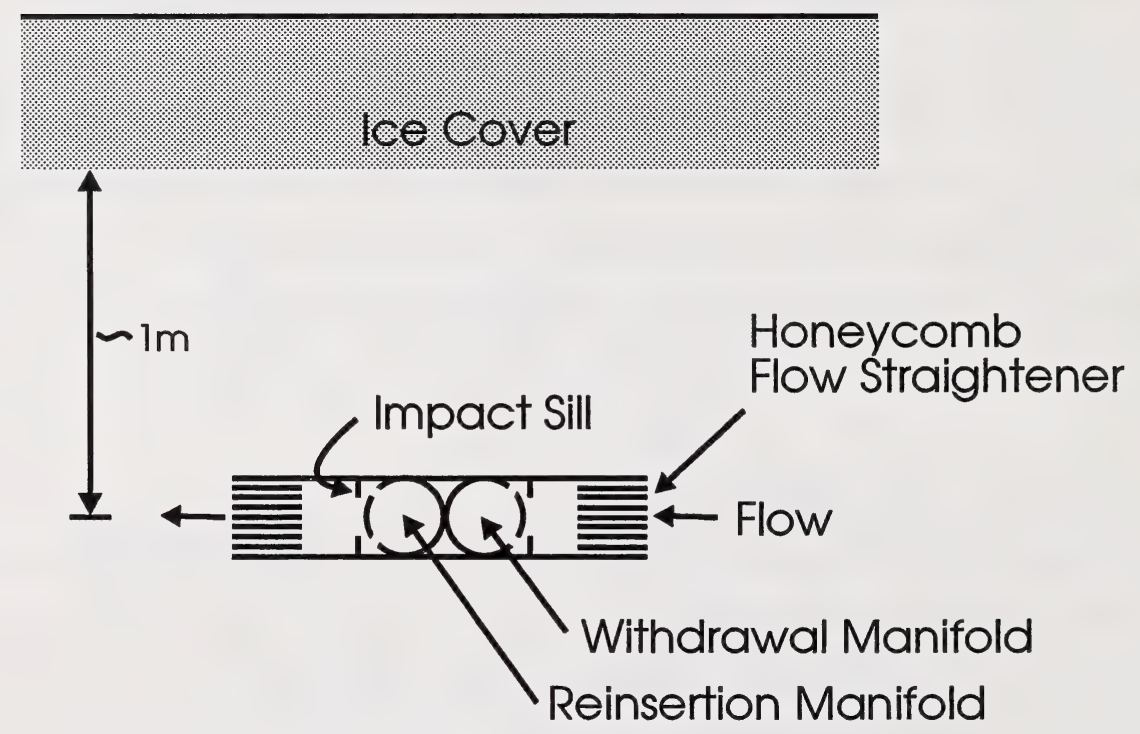

Figure 9. An ice-preserving aeration system designed by Ellis and Stefan (1990). The manifold/diffuser is designed to aerate a thin horizontal layer of water while minimizing heat transfer to the lake surface and oxygen transport to the sediments. The intake manifold and outflow diffuser can be separated to minimize the recycling of aerated water and ensure its release at an appropriate depth.

When used with oxygen injection, DBCA can achieve 80-90\% absorption efficiency and can supersaturate outflowing water with oxygen (Speece et al. 1971). This high efficiency results primarily from the countercurrent flow of water and air within the cone which maximizes bubblewater contact time and maintains a favourable gradient for oxygen transfer. DBCA is considered to be energy efficient because the high rate of oxygen transfer minimizes the amount of water and air or oxygen flow required (Speece 1971; Speece et al. 1971; Fast and Lorenzen 1976). 
Furthermore, since water flow is used to push air bubbles downward, expensive high pressure compressors are not required in DBCA; low pressure blowers are sufficient (Speece 1971).

Although DBCA was first proposed in the early 1970's, a full scale DBCA system for lake aeration has not been deployed until very recently. The first and only DBCA system in use for lake aeration (Fig. 11) was installed in Newman Lake, Washington in June 1992 (Funk et al. 1994). Newman Lake has a surface area of approximately 1,200 acres (486 hectares), a maximum depth of 9 metres, and is heavily used for domestic water supply and recreation. Because the purpose of artificial aeration at Newman Lake is improvement of water quality without enhancement of internal nutrient loading, it was deemed necessary to selectively aerate the hypolimnion.

The decision to use DBCA at Newman Lake was based primarily on logistic considerations. Traditional full lift aerators (see next section) were originally proposed for Newman Lake (Ashley 1990). However, preliminary estimates indicated that aeration of Newman Lake would require six full lift aerators which would be powered by a total of three 75 hp compressors (i.e. two aerators per compressor). That number of full lift aerators would have been aesthetically unpleasing and created hazards for seaplanes and recreational boaters. The DBCA system does not possess these drawbacks because it is completely submersible. The DBCA system is also believed to require somewhat less horsepower than an equivalent full lift system. The total cost of the DBCA system in Newman Lake including system design and planning, equipment purchase, and installation was about $\$ 520,000$. Annual operating expenses are approximately $\$ 30,000$ (Brenda Simms, personal communication).

Until DBCA systems are more thoroughly tested, they should probably be regarded as having some logistic advantages over other hypolimnetic aerators, but requiring approximately similar capital and operating costs. 


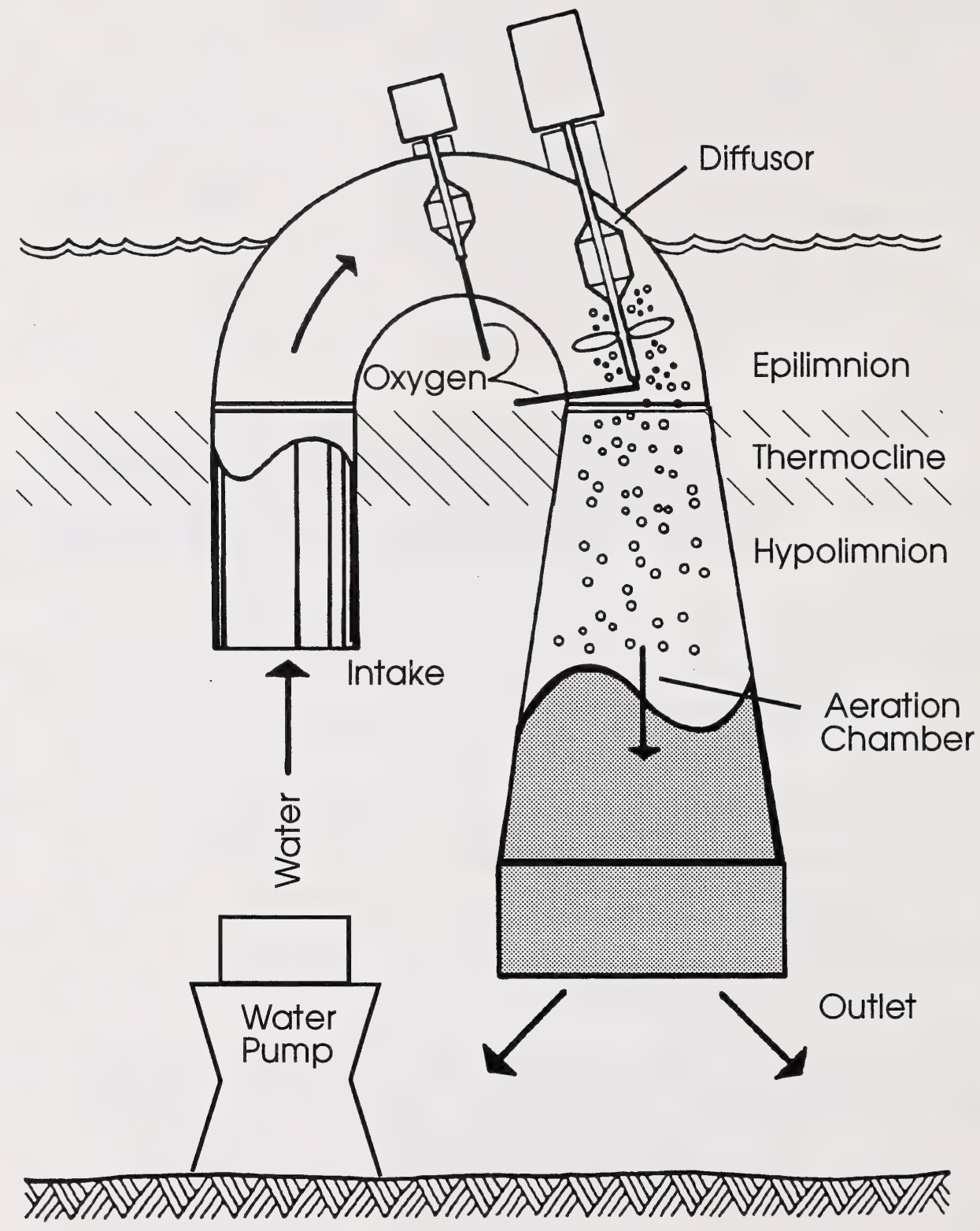

Figure 10. Model of a downflow bubble contact aeration (DBCA) system (modified from Seppanen 1974). Note the cone-shaped aeration chamber developed by R.E. Speece. Within the aeration chamber, a downward flow of water opposes the buoyant rise of air or oxygen bubbles thereby increasing oxygen transfer efficiency. 


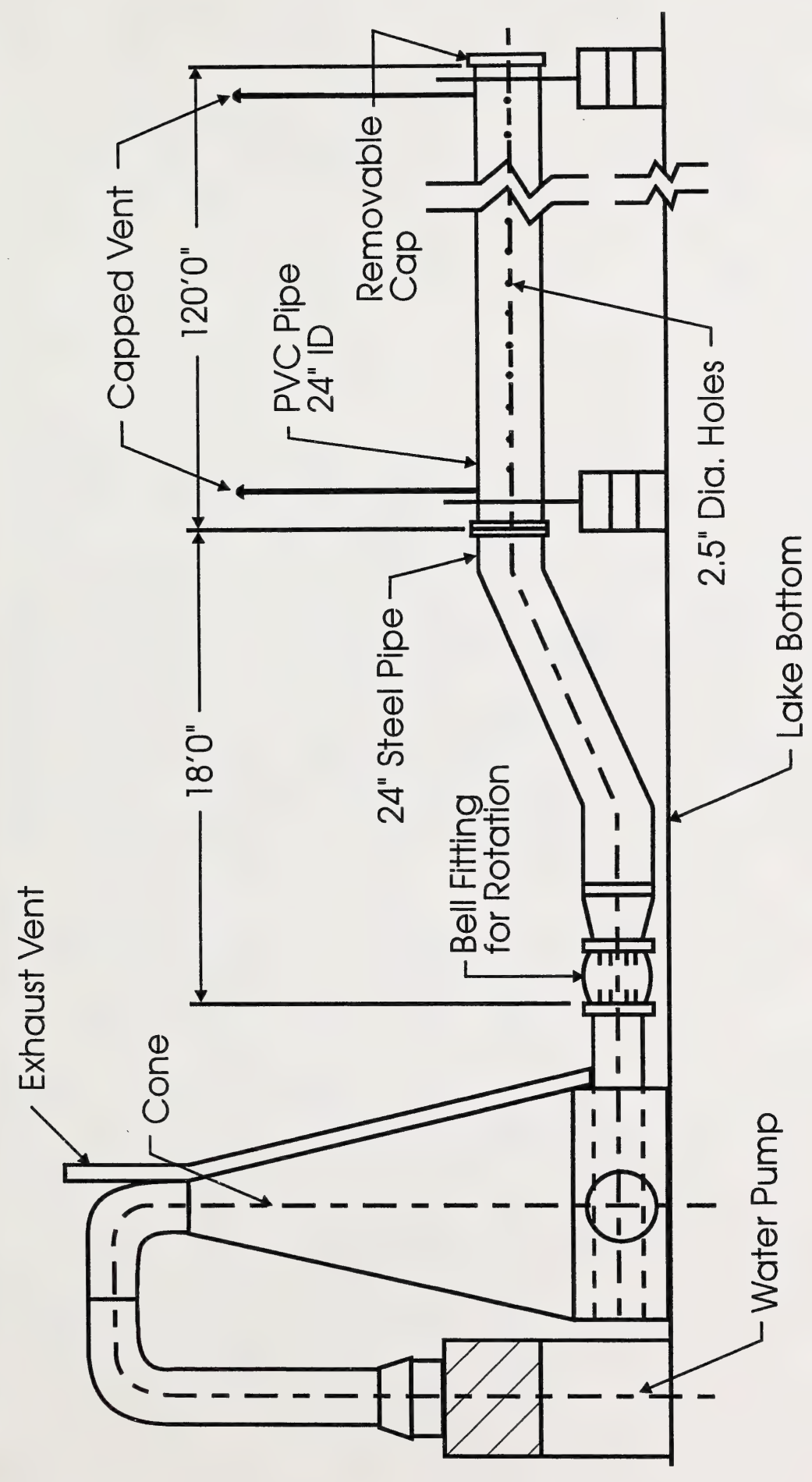

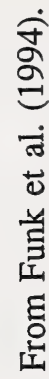

몸

胥

ส

류뮤

离

인

4

壱

ت 


\subsection{Hypolimnetic Aeration}

These aeration systems are commonly used to selectively aerate the hypolimnion of lakes which stratify thermally in summer. Although hypolimnetic aerators are not widely used to mitigate winterkill, a discussion of these systems is provided because they illustrate some useful concepts in lake aeration and offer some advantages compared to other aeration techniques. Hypolimnetic aeration has been used for several purposes including maintenance of suitable fish habitat in deeper water, control of algae blooms, reduction in internal nutrient (phosphorous) loading, elimination of toxic compounds $\left(\mathrm{H}_{2} \mathrm{~S}, \mathrm{NH}_{3}, \mathrm{CH}_{3}\right)$, and preservation of ice cover during lake aeration in winter (Smith et al. 1975; Fast et al. 1976; Lorenzen and Fast 1977; Fast 1978).

The most common type of hypolimnetic aerator is the full air lift design illustrated in Fig. 12. Several additional full air lift designs exist (see Fast and Lorenzen 1976), but they all operate on the same principle. The term full air lift indicates that water upwelled by air bubbles in the inflow tube rises completely to the lake surface before being returned to the hypolimnion via the outflow tube. A degassing chamber which connects the inflow and outflow tubes provides additional area for oxygen absorption and prevents air bubbles from being swept into the hypolimnion where they might cause unwanted mixing of lake water. These aerators can be constructed of any suitable material including sheet metal, corrugated piping, molded plastic, and fibreglass. However, the inflow pipe must be sufficiently rigid to avoid collapsing under the hydrostatic pressure exerted from outside (Lorenzen and Fast 1977). Additionally, the entire aerator must be watertight because leaks have been known to cause significant mixing of eplimnetic and hypolimnetic water (Fast 1973). If the aerator will not be operated in winter, it can be lowered into the lake by means of ballast and thereby stored safely without risk of damage from ice (Soltero et al. 1994). The aerator can be operated in winter if a bubble curtain is used to create a small ice-free area around the aerator. Simply installing the degassing chamber on the ice surface or allowing it to freeze within the ice may not work because in both cases the chamber will be raised above the water surface. Air-lifted water is unable to overcome even a small head (Wirth et al. 1975). 


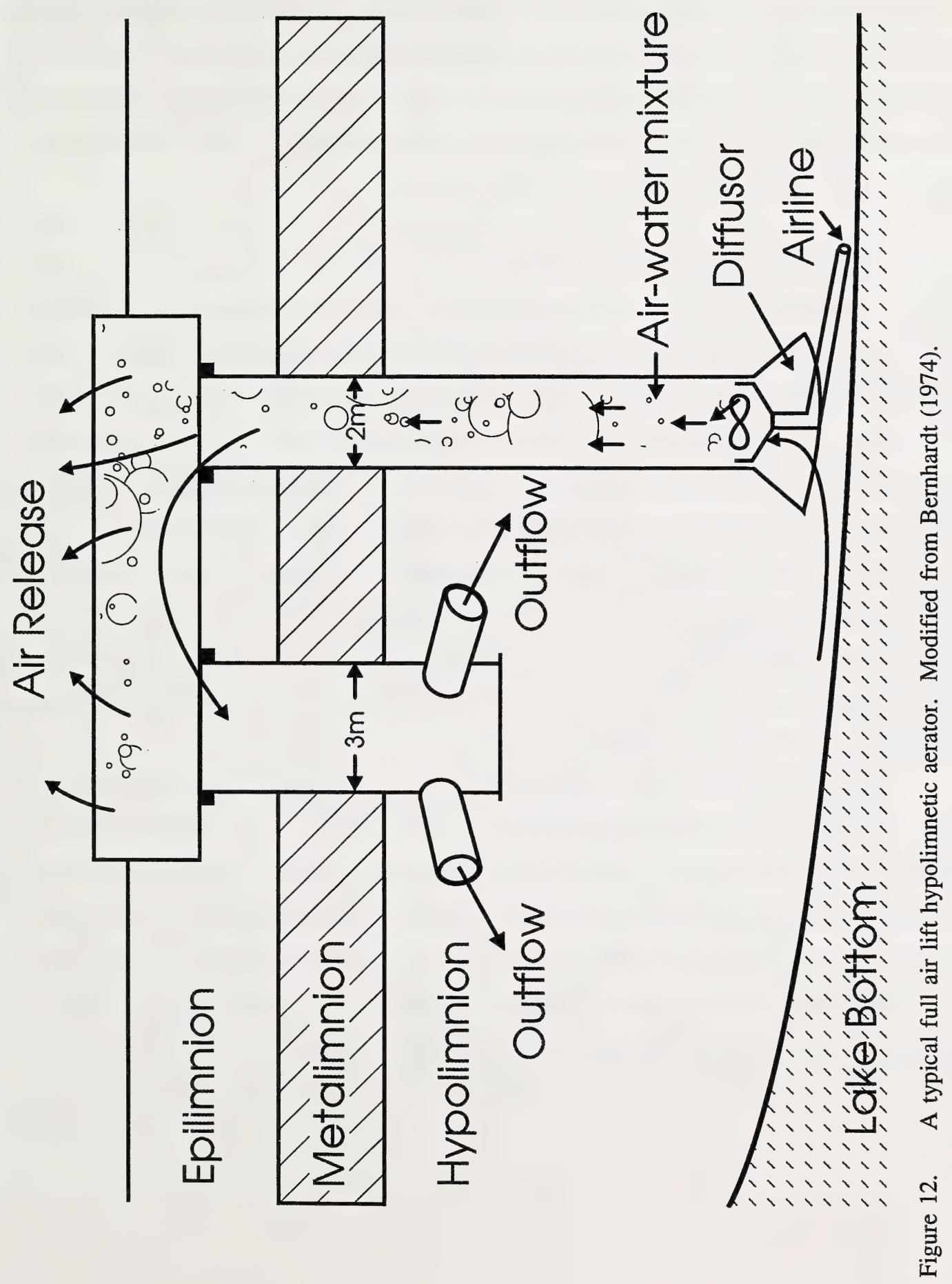


As with any aerator, the oxygen transfer rate of the full air lift design is difficult to predict and depends on such factors as the depth of air injection, bubble size and height of rise, air flow rate, and the amount of water surface area in the degassing chamber (Lorenzen and Fast 1977; Ashley 1985). For proper operation, the cross-sectional area of the outflow tube must be at least as large as that of the inflow tube so that water flow is not restricted (Ashley 1985). Additionally, the air:water ratio in the inflow tube should not exceed 1:10 or else oxygen transfer efficiency and water flow will likely be impaired (Ashley 1987).

It is important to note that in full lift aerators the bubble plume is restricted by being inside the inflow tube and the amount of lake surface area available for absorption of atmospheric oxygen is also limited. Therefore, if factors such as depth of air injection, bubble size, and airflow rate are equal, full lift aerators may be considerably less efficient in oxygen transfer than diffused air systems which create open bubble plumes and large ice-free surface areas.

Partial air lift systems are a second type of hypolimnetic aerator. As their name suggests, these aerators do not transport the air-water mixture to the lake surface. Instead, the separation of air from the upwelled water occurs well below the lake surface, usually within the upper hypolimnion. Partial lift aerators exist in several designs (see Fast et al. 1976) of which one of the most common is shown in Fig. 13. In these aerators the escape of gas through the discharge line is restricted thus forming an air pocket in the upper part of the aeration chamber (Fig. 13). The air pocket ensures that oxygenated water returns to the hypolimnion through the outflow tubes rather than escaping through the air discharge line.

The smaller distance available for bubble rise makes partial air lifts much less efficient in oxygen transfer than full lift aerators. A short bubble rise lowers oxygenation efficiency by moving less water, shortening air-water contact time, and allowing less time for bubbles to expand after being released from the diffusor (Lorenzen and Fast 1977). The low efficiency of partial lift aerators has been shown in numerous studies (Fast et al. 1976; Lorenzen and Fast 1977; Soltero et al. 1994). Partial air lifts cannot be recommended and will likely disappear from use once their inefficiency becomes more widely known. 
Determining the size of aeration equipment that ensures fish survival at lowest cost is perhaps the most difficult task in lake aeration. Optimum sizing of aeration equipment requires an understanding of the biological and chemical processes responsible for aeration induced increases in lake oxygen consumption, the dynamics of water flow and oxygen dispersal, fish oxygen requirements, and their behavioural responses to oxygen gradients.

\section{Bubble Plumes}

Aeration methods which rely on unenclosed bubble plumes are particularly difficult to size optimally. A mathematical method devised by Lorenzen and Fast (1977) appears to be the only published sizing method presently available for bubble plume aeration systems. The sizing method assumes that aeration is conducted in summer for the purpose of destratifying the lake so as to minimize vertical variations in temperature and algal density. Lorenzen and Fast developed their sizing method by first constructing mathematical models for predicting temperature and algal density as a function of lake depth and vertical water flow rates induced by bubble plumes. The model was then used to predict the minimum water flow required to destratify a given size of lake, destratification being indicated by a maximum vertical temperature gradient of less than $2^{\circ} \mathrm{C}$. The air flow rate $\left(\mathrm{m}^{3} / \mathrm{s}\right.$ at 1 atm pressure) which produces the required water flow was estimated from a model developed by Kobus (1972). According to this model, upwelling flow depends primarily on the depth of air release and air flow rate. It should be noted that slip velocity and the mass transfer of oxygen out of the air bubbles, both factors which influence water flow rate induced by rising air bubbles (Speece et al. 1973b), were not considered in Kobus's (1972) model. Results of these simulations were summarized in a table (Lorenzen and Fast 1977; Lorenzen 1977) which indicates the approximate air flow required to mix a variety of lakes differing in size and depth. The simulations suggest that the air flow required for mixing increases nearly linearly with lake area and is nearly independent of lake depth. As a "rule of thumb" Lorenzen and Fast (1977) propose that approximately 30 standard cubic feet per minute (SCFM) per $10^{6} \mathrm{ft}^{2}$ surface area will provide good mixing. This is equivalent to 1.3 SCFM of air per acre. 


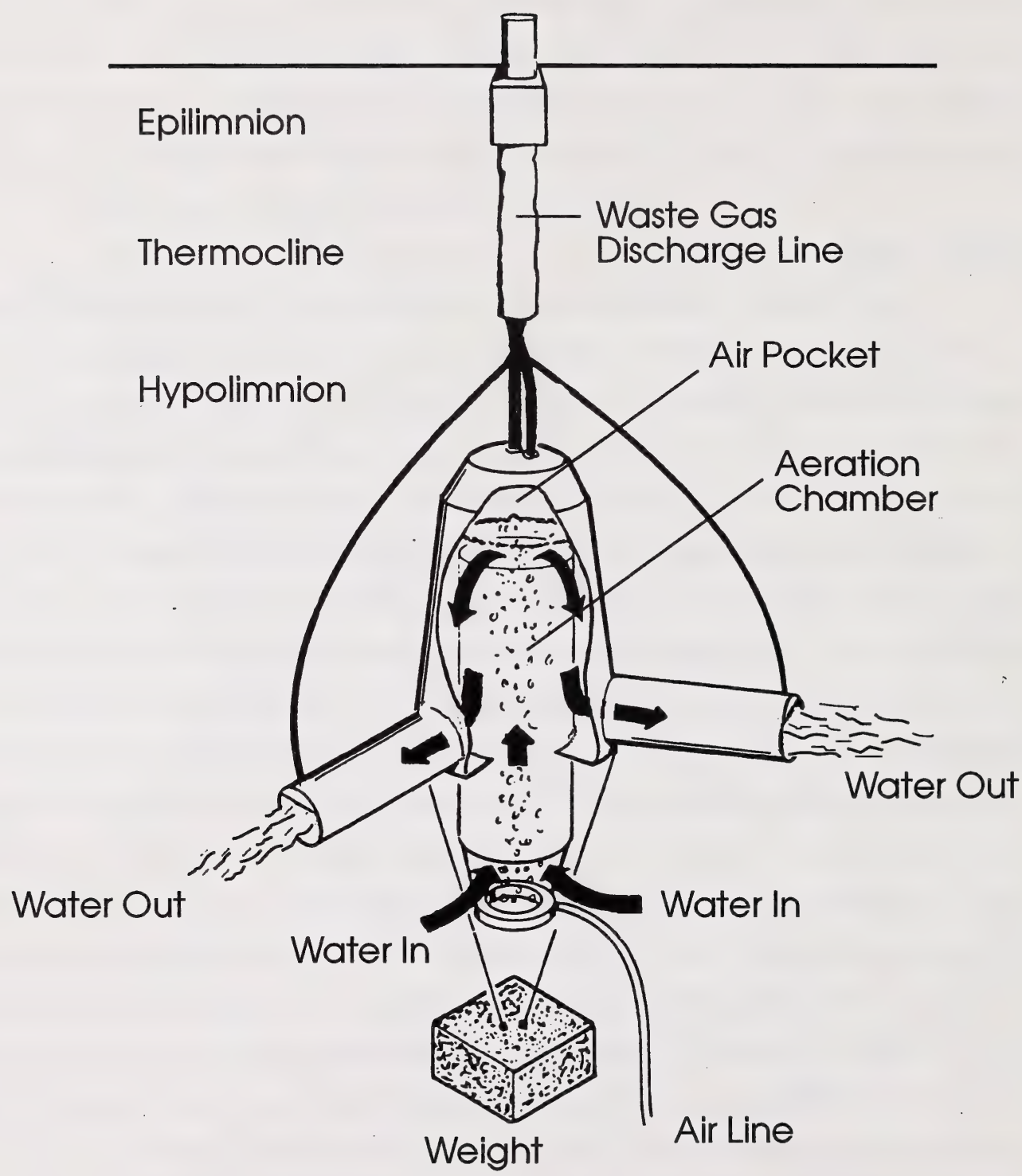

Figure 13. Example of a partial air lift hypolimnetic aerator. From Lorenzen et al. (1977). 
The next step in the sizing method involves designing a diffusor which will deliver the calculated air flow rate. Lorenzen and Fast (1977) suggest that since a rising plume will spread horizontally at a rate of about 0.05 feet per foot of rise, orifice spacing should be at least 0.1 times the depth of air release. The total length of the diffusor is then determined by dividing the total air flow required by the flow through each orifice which can be calculated from orifice diameter, pressure drop, and the weight density of air. Further refinements in orifice spacing can be made if pressure loss along the diffusor is substantial. In that case, orifices should be spaced closer together as they approach the end of the diffusor to ensure an even distribution of airflow.

Selecting an appropriately sized compressor or blower is the final step in the sizing procedure. The compressor must be sufficiently powerful to overcome the hydrostatic water pressure existing at the injection depth and the pressure losses along the distribution lines. The latter can be easily determined from nomographs available from suppliers of air supply lines. Lorenzen and Fast (1977) recommend that air pressure at the diffusor exceed hydrostatic pressure by 5 to 10 psi. When sizing a compressor, it is important to realize that compressors are rated according to the volume of air they deliver when open to the atmosphere. Because gasses are highly compressible, the air flow delivered at the injection depth will be considerably less than the rated performance of the compressor. Therefore, if the sizing procedure specifies the air flow required at the diffusor, those flow rates must be adjusted according to the depth at which air will be injected (Ashley 1985). Once the pressure and air flow rating of the compressor have been estimated, compressor size (horsepower or $\mathrm{Kw}$ ) is best determined by consulting the compressor manufacturer.

Lorenzen and Fast (1977) recommend their sizing method only as a guide which should be modified according to local conditions. Therefore, it is surprising that this sizing method has been used in designing compressed air systems for winterkill remediation. When used for winterkill remediation, the sizing method of Lorenzen and Fast (1977) suffers from several serious limitations. First, the method does not address lake oxygenation per se and thus does not incorporate the important effects that aeration-induced oxygen demand, under-ice photosynthesis, and ice-free surface area have on lake oxygen content. Moreover, the sizing method does not address the creation of aerated refuges or cells nor does it attempt to define the minimum level of oxygenation needed to allow fish survival. Fish survival is undoubtedly accomplished with much less aeration than that required to mix and fully oxygenate the entire lake volume. 
A field survey conducted in Wisconsin (Wirth 1988) appears to be the only experimental attempt to derive guidelines for sizing compressed air systems for winterkill remediation. Thirty two aerated lakes were surveyed during February and March 1986 to determine $\left[\mathrm{O}_{2}\right]$, the ice-free surface area created by aeration, and the relative success of each aeration system in overwintering fish (Wirth 1988). The most successful aeration systems provided an average of 0.82 SCFM of air per surface acre and maintained an ice-free area amounting to $2.3 \%$ of lake surface area. Satisfactory systems averaged 0.25 SCFM per acre in air flow and $1.3 \%$ ice-free area, whereas marginal or failing systems provided only 0.13 SCFM of air per acre and $0.73 \%$ ice-free area (Wirth 1988).

Perhaps surprisingly, satisfactory airflow rates reported by Wirth (1988) are only modestly lower than the value of 1.3 SCFM per acre recommended by Lorenzen and Fast (1976) for lake destratification. Nevertheless, the guidelines arising from the Wisconsin survey should be treated with some caution because such factors as fish species composition, sediment oxygen demand, and water chemistry were not taken into account. Airflow rates required to overwinter salmonids in Alberta lakes may vary from those required in Wisconsin where winterkill lakes are managed for gamefish such as bass, bluegills and crappie in addition to salmonids.

\section{Hypolimnetic Aerators}

Most hypolimnetic aerators are easier to size than bubble plumes because water flow is contained within the aerator and is thus more amenable to measurement and modeling. The principle on which the common Bernhardt full lift aerators operate is a difference in density between the air-water mixture in the upwelling tube and the surrounding water. This difference in density creates a hydraulic head which draws water into the upwelling tube and forces it out the downflow tube. Several authors have used this operating principle to devise sizing methods for hypolimnetic aerators (Lorenzen and Fast 1977; Taggart and McQueen 1982), but only the method of Ashley (1985) will be described because it builds on the earlier methods. The sizing method begins with estimates of maximum hypolimnetic oxygen consumption ( $\mathrm{mg} \mathrm{O}_{2} /$ day) and aerator input rate $\left(\mathrm{mg} \mathrm{O}_{2} / \mathrm{L}\right)$. Maximum hypolimnetic oxygen consumption is estimated empirically at the beginning of summer stratification before lake oxygen consumption becomes limited by low oxygen levels. Aerator input rate depends on many factors, including the depth of air injection, bubble size and height of rise, and the surface area of water in the separator box. 
Because aerator input rate is difficult to predict in advance, Ashley (1985) indicates that it must be estimated from experience or literature values reported for similarly designed aerators. Published input rates for full air lift aerators range from $0.7 \mathrm{mg} \mathrm{O}_{2} / \mathrm{L}$ to $9.0 \mathrm{mg} \mathrm{O}_{2} / \mathrm{L}$. (Ashley 1985). The amount of water flow required for effective aeration is estimated by dividing maximum hypolimnetic oxygen consumption ( $\mathrm{mg} \mathrm{O}_{2} /$ day) by aerator input rate ( $\mathrm{mg} \mathrm{O}_{2} / \mathrm{L}$ ).

Once the required water flow $\left(\mathrm{m}^{3} / \mathrm{s}\right)$ has been determined, the cross-sectional area $\left(\mathrm{m}^{2}\right)$ of inflow and outflow tubes necessary to handle this flow can be calculated if the velocity of water rise $(\mathrm{m} / \mathrm{s})$ in the inflow tube is known. Ashley et al. (1987) suggest that a median rise velocity of $0.45-0.50 \mathrm{~m} / \mathrm{s}$ can be used when data on bubble size is not available. The next step involves estimating the amount of hydraulic head necessary to overcome gravitational and frictional forces to achieve the required rate of water flow. Thereafter, the density of air-water mixture which produces the required amount of hydraulic head is determined. Since the density of air-water mixture in the inflow tube is dependent on air flow rate, that flow rate is calculated from physical principles. Finally, once the required air flow rate is known, compressor pressure and power requirements are determined as described previously for diffused air systems.

\section{Limitations of aeration sizing methods}

At present, the sizing of lake aeration systems is not an exact science. Although the sizing methods described earlier reflect sound engineering principles, they nevertheless suffer from several serious limitations. These limitations exist because the limnological and biological processes which govern lake oxygen demand and fish survival remain poorly understood. The main limitations of existing lake aeration sizing methods are:

1. There are no reliable methods available for predicting the increase in lake oxygen demand which usually accompanies artificial aeration. The lake oxygen demand induced by artificial aeration has been reported to range from negligible to as much as 4-6 times the pre-aeration rate (Bandow 1986; Smith et al. 1975). Underestimating the magnitude of the induced oxygen demand is the most common problem encountered in lake aeration. The magnitude of induced oxygen demand depends on characteristics of the lake (e.g. the capacity for biological and sediment oxygen consumption) and of the aeration method (e.g. the amount of water and oxygen circulated to the sediments). 
2. The oxygen input rates of aerators are difficult to predict. In theory it should be possible to predict the increase in water oxygen concentration between the inflow and outflow of an aerator from the principles of physics. However, in actual practice much of the oxygen transferred by the aerator is used in the rapid oxidation of reduced inorganic compounds such as $\mathrm{Fe}^{2+}$ and $\mathrm{Mn}^{2+}$ and does not contribute towards raising water oxygen concentration. This phenomenon has been termed immediate oxygen demand (Taggart and McQueen 1982; Ashley 1987) and contributes to the wide variation in oxygen input rates reported in the literature for aerators of similar design (Ashley 1987).

3. The feasibility of creating oxygenated refuges and the size of refuge necessary for overwinter fish survival is unknown. In most winterkill lakes fish survival can probably be achieved by aerating only a small portion of the total lake area and only a portion (ideally the top few metres) of the water column so as to create a refuge. However, there probably exists a size of lake below which the dynamics of water flow and oxygen dispersal make it impossible to create such a refuge. In those lakes one has no choice but to aerate the entire lake. Conversely, the aeration of large winterkill lakes may only be economically feasible if refuges (of sufficiently small size) can be created. To resolve this problem it is imperative that the zone of influence created by aeration practices be quantified. The zone of influence will be defined in large part by the distances to which oxygen is dispersed from an aeration site and the distances from which fish can be attracted to the oxygenated refuge.

Recently, more definitive engineering principles have been used in modeling lake dynamics in response to artificial aeration systems. These models may ultimately provide the basis for reliable methods of sizing lake aeration systems. A heat budget model developed by Rogers (1992) predicts water temperature, ice thickness, and the size of open water area (polynya) created by mechanical surface aerators. The model applies to small kettle lakes in British Columbia and was intended to be the first step towards a more comprehensive model of lake oxygen dynamics. Variables accounted for in the model include turbulent heat transfer from circulated water to the ice cover, heat losses due to evaporation and snowfall on open water, sediment heat transfer, snowmelt due to rain, white ice formation, and daily variations in snow thickness, density, conductivity, and albedo. 
Schladow $(1992,1993)$ has developed a novel approach to modeling bubble plumes for lake destratification. The model predicts the number of plumes and their individual airflow rates necessary for efficient destratification while minimizing total airflow rate. According to the model, a bubble plume will rise until the density of the air-water mixture equals that of the surrounding water column, at which point the entrained water separates from the rising bubbles. A second entrainment process begins above the level at which the initial plume detrains. The number of vertically stacked plumes which develop depends on the strength of density stratification and the strength of the bubble plume (i.e. airflow rate). Schladow $(1992,1993)$ predicted that the most efficient air flow rate for an individual plume corresponds to the situation in which the plume has one internal detrainment and reaches the surface with only a slight excess of momentum (i.e. almost a two tiered plume). The inclusion of oxygen transfer phenomena into lake dynamics models such as those developed by Rogers (1992) and Schladow $(1992,1993)$ appears to be a profitable approach to sizing lake aeration systems.

\subsection{Review of Lake Aeration in Alberta}

In Alberta, artificial aeration for the purpose of averting winterkill began in 1966 at Little Chickakoo and Halfmoon lakes (Hunt 1967; Bidgood 1967). Compressed air injection and point release diffusers were used at both lakes. Little Chickakoo Lake was aerated from October 26 to November 23, 1966 whereas Halfmoon Lake received two periods of winter aeration, from October 17 to November 14, 1966 and again from February 11 to April 5, 1967. Both systems apparently induced considerable amounts of oxygen consumption and were not successful in maintaining adequate oxygen levels or averting winterkill (Hunt 1967; Bidgood 1967).

During the 1970's and early 1980's artificial aeration was becoming established as an effective lake rehabilitation technique in other provinces and the northern United States but was not widely practiced in Alberta. However, this situation changed dramatically in the mid 1980's when establishment of the provincial Buck for Wildlife program created a source of funds for habitat development projects. Since 1985, at least 15 Alberta lakes have been artificially aerated (Table 5). Much of the development of lake aeration technology in Alberta has been conducted in the Peace River/Grande Prairie region.

Incomplete autumnal circulation has been established as an important cause of low winter $\left[\mathrm{O}_{2}\right]$ at Spring and Mayatan lakes. Fall turnover is incomplete in these lakes because they are 
relatively deep and protected from winds by the local topography. Spring and Mayatan lakes are aerated for only a brief period in fall to ensure a level of oxygenation sufficient to avert winterkill. Other aerated lakes in Alberta are too shallow to hold a sufficiently large reservoir of oxygen and require artificial aeration for the entire winter period.

Air injection with compressors or blowers appears to have been the only aeration technique ever used in Alberta for winterkill mitigation. Many of Alberta's aeration projects initially used diffuser hoses as the air release mechanism, but point releases are becoming the preferred type of diffusor. There is also a tendency to increase the number of point releases used to deliver a given volume of airflow. Several small diffusers seem to create more open water than a single large diffuser.

Interestingly, the air injection rates of Alberta systems are often much greater than those of systems which give excellent results in Wisconsin. Among 26 compressed air systems in Wisconsin the six most effective systems injected air at an average rate of 0.82 SCFM per acre, with the highest injection rate being 1.36 SCFM per acre (Wirth 1988). In Alberta, the systems at Figure Eight Lake, East Dollar Lake, Poirier's Pond, and Zama Pond have injection rates ranging from 1.60 to 3.92 SCFM per acre. Those rates are 2 to 4 times the average rates giving effective results in Wisconsin. The apparent differences in airflow requirements between Alberta and Wisconsin systems cannot be explained on the basis of lake depth. Average maximum depth for the six Wisconsin lakes was 19.3 feet (Wirth 1988) compared with 18.8 feet for the four Alberta lakes. These comparisons suggest that Alberta lakes either require higher rates of aeration compared to Wisconsin lakes or else are oversized.

Most aerated lakes in Alberta did not contain native gamefish species prior to aeration. With the exception of Mayatan Lake which supports a yellow perch and northern pike fishery, aerated lakes in Alberta are managed for salmonids, primarily rainbow trout. The aerated lakes tend to be shallow and highly productive and have an abundant food supply. Consequently, rainbow and brook trout in these lakes exhibit fast growth. At Spring Lake for example, rainbow trout stocked as fingerlings in May reach weights of 1.5 to $1.7 \mathrm{~kg}$ by age three (Ed Kolodychuk, unpublished data).

A research project on hypolimnetic aeration with liquid oxygen injection has been conducted at Amisk Lake (Prepas et al. 1990; Dinsmore and Prepas 1993). 


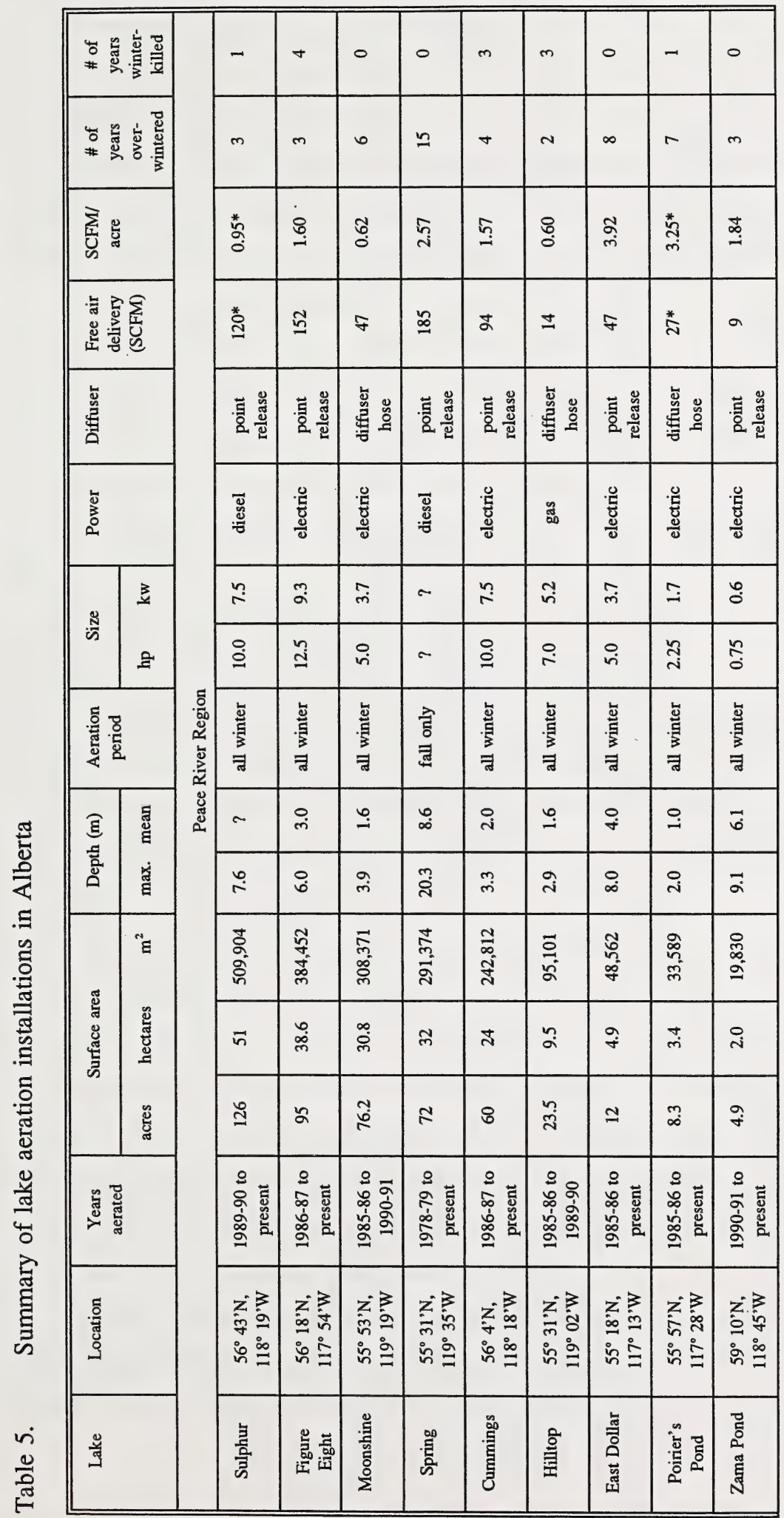


62

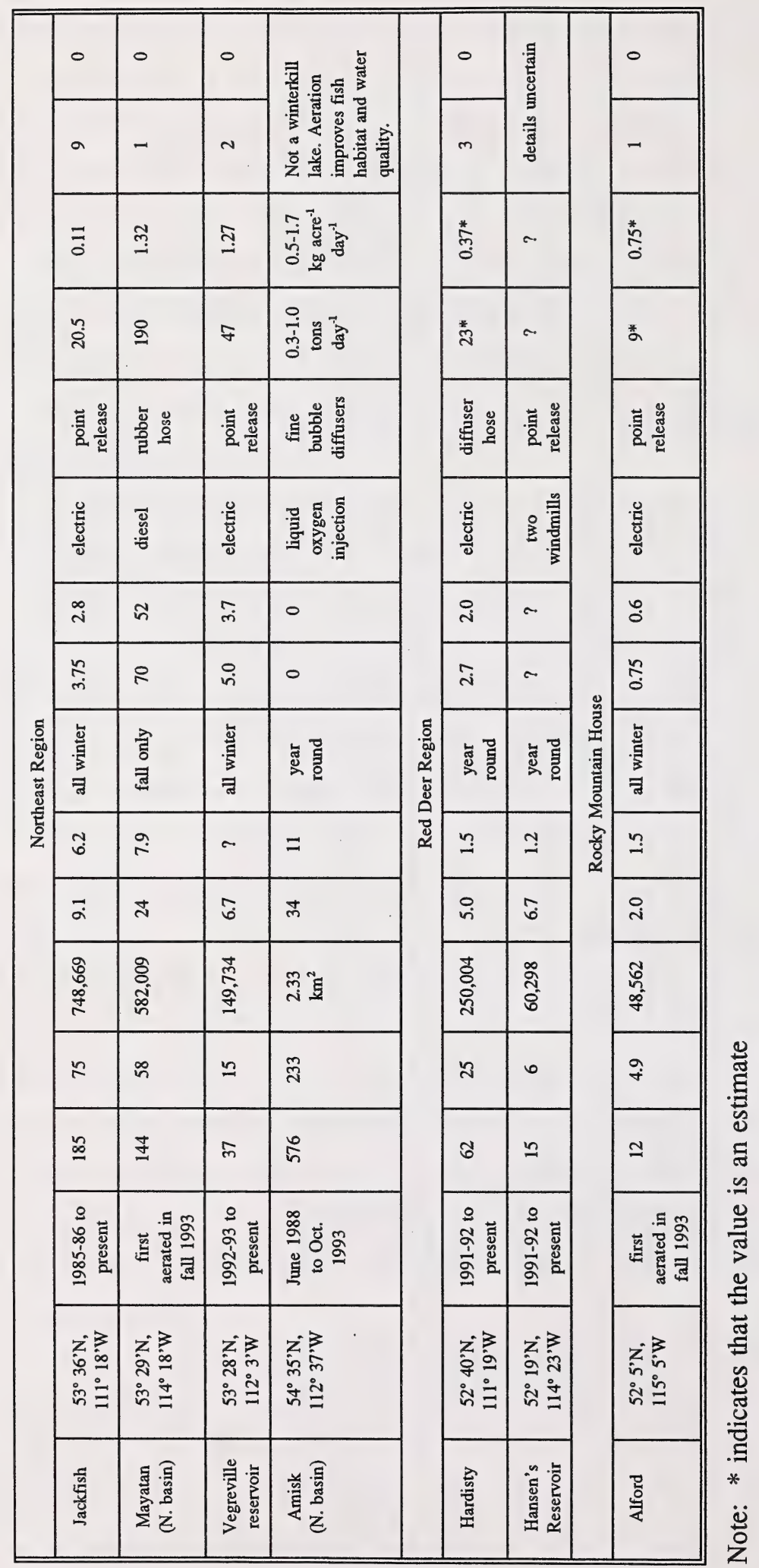




\section{Fisheries evaluation}

The evaluation process should begin before aeration projects are implemented to ensure that the candidate lakes have been selected carefully. In a review of artificial circulation in British Columbia, Ashley (1987) concluded that site selection was the most important factor influencing the potential cost effectiveness of lake aeration. Careful site selection avoids the inappropriate aeration of lakes that are not attractive to anglers, that do not winterkill, or lakes whose water chemistry does not allow fish survival. Background assessment of lake oxygen dynamics will indicate whether winterkill can be averted with a brief period of aeration in fall to ensure turnover or whether aeration for the entire winter is necessary. Portable aeration systems, rather than permanent ones, should be considered for use on lakes which winterkill infrequently.

Another important consideration is whether the lake's fishery will be maintained by stocking or by natural reproduction. Occasional winterkills might be tolerable on smaller lakes with a fishery maintained by stocking because such fisheries can be re-established relatively quickly. However, naturally reproducing fish populations usually require many years to reestablish themselves after a winterkill. Large lakes which support significant fisheries through natural reproduction may require protection from even occasional winterkills because the latter may have long term effects.

Evaluating the success of existing aeration projects can be done on several levels (Ashley 1987), beginning with the monitoring of winter oxygen levels and over-winter fish survival. Fisheries staff nearly always gather this information on the aeration projects they operate and use this information to improve their aeration methods. Unfortunately, because of budgetary limitations, these data are seldom gathered or presented in a scientifically rigorous manner which facilitates the transfer of improved aeration methods to other jurisdictions. Consequently, fisheries staff in different geographic regions must do their own experimentation with aeration methods and often end up "re-inventing the wheel".

The second level of evaluation involves measurement of fish survival, growth and catchability. In this context, fish survival measurement does not refer to simple confirmation of whether or not winterkill occurred but rather involves year round survival rates to determine the 
proportion of stocked fish present in the lake at various intervals (years) after planting. It is important to monitor fish survival, growth, and catchability because these factors influence the quality of fishery and angler satisfaction created by the aeration project.

Monitoring the response of anglers in terms of their fishing effort, success, and overall satisfaction before and after lake aeration is the final level of evaluation. Again, fisheries staff are sufficiently familiar with fish and angler responses to assess whether their aeration projects have had a beneficial impact on the fishery. However, the amount and cost of data collection necessary to quantify angler responses and fish survival, growth, and catchability accurately enough for cost-benefit assessment is usually considered prohibitive. This is especially a problem on small lakes because the value of the fishery often appears insufficient to justify the cost of collecting accurate fishery statistics.

To reduce the costs of evaluating management initiatives on small lakes in British Columbia, Parkinson et al. (1988) have attempted to define the minimum sample sizes necessary to detect changes in fishery statistics (fish growth, angler effort, CPUE). The method involves estimating the quantity $\mathrm{SD} / \mathrm{X}$ for each fishery statistic from a preliminary data set. Sample sizes (N) can be calculated from the equation $\mathrm{N}=100^{2} \mathrm{k}(\mathrm{SD} / \mathrm{X})^{2} / \mathrm{p}^{2}$. The parameter $\mathrm{k}$ relates variability in the fishery statistic with the levels of type I and II error rates and can be calculated or obtained from a table supplied by Parkinson et al. (1988). The minimum detectable change, expressed as a percentage of the mean, is denoted as "p." Parkinson et al. (1988) concluded that a 50\% change in angler effort, a 30\% change in CPUE, and a 10\% change in fish length could be detected at small trout lakes in British Columbia at reasonable cost with a combination of aerial surveys and creel surveys. Although the results of Parkinson's study apply only to lakes in southern British Columbia, a similar approach could be used to determine the feasibility of collecting reliable fisheries statistics on small lakes in Alberta.

\section{Economic evaluation}

Habitat management practices can be difficult to justify unless they generate benefits having a real or perceived value that exceeds the cost. Consequently, there is a real need for proper economic evaluation of lake aeration projects. Such evaluation can be used to compare the cost-effectiveness of lake aeration with that of other habitat management practices, to compare the cost-effectiveness of different aeration techniques, and to monitor improvements in 
the cost-effectiveness of ongoing aeration programs. Cost-benefit analysis can also be used to determine if there are economies of scale to be gained from the aeration of large winterkill lakes.

Ashley (1987) presents one of the very few cost-benefit analyses available for lake aeration projects. In that analysis, cumulative costs and benefits are recorded for each year of the aeration project. To accurately determine the total cost, it is important to identify all individual costs, including power line installation, capital and operating expenses incurred in running the aeration equipment, repairs, labour, fish stocking costs, and preliminary surveys to document lake oxygen dynamics and water chemistry. Ashley (1987) estimates the benefits generated by lake aeration by multiplying the number of fish stocked by estimates of annual survivorship (0.5) and catchability (0.6) to determine the number of fish which will ultimately be caught by anglers. That value is then divided by the number of fish caught in an average angler-day to determine the number of angler-days generated by the stocked fish. Finally, a monetary value ( $\$ 20)$ is attached to an angler-day so that total benefits can be expressed as dollar values for comparison with the total cost of aeration. Since the benefits from lake aeration usually extend beyond the analysis period, a discount rate (10\% per year) is applied to both the costs and benefits (Ashley 1987). In Ashley's (1987) analysis, total costs exceed benefits for the first year or two after aeration until the stocked fish are large enough to be caught by anglers.

Several important implications arise from Ashley's method of cost-benefit analysis. First, because the effect of individual variables contributing to benefits is multiplicative, these variables have a relatively large effect on the cost/benefit (C/B) ratio compared to individual costs, which are additive. This emphasizes the need for accurate estimates of fish survivorship and catchability, fish per angler-day, and the monetary value of an angler-day. Second, discount rate variations of $50 \%$ were found to have relatively little effect on $\mathrm{C} / \mathrm{B}$ ratios. Finally, Ashley's analysis showed that among small trout lakes in British Columbia aeration costs expressed per hectare declined as lake area increased. This economy of scale was attributed to fixed costs such as electrical installation and compressor shed construction which were independent of lake size and from cost savings associated with the purchase of larger aeration equipment. Ashley's (1987) cost comparisons involved lakes up to 70 hectares in size. In lakes hundreds to thousands of hectares in size, it may be possible to achieve additional economies of scale if fish can be attracted to aeration sites from long distances. If the fish population of a large lake can be safely 
over-wintered in a relatively small refuge surrounding the aeration site, then it is not necessary to aerate the entire lake.

A serious limitation of Ashley's (1987) method of cost-benefit analysis is that it does not compare the benefits of a large trout fishery created by lake aeration with the benefits of a panfish fishery created in the absence of aeration by the annual stocking of yearling trout. The method therefore overestimates the benefits attributable to lake aeration. In Alberta, this problem is avoided because cost-benefit analysis is performed by comparing the costs of aeration with the cost savings which result from the stocking of fingerling trout rather than yearlings. Cost-benefit analysis performed in this way underestimates the benefits achieved by aeration. For example, in 1992 the cost of stocking yearlings was estimated to be $\$ 962 /$ ha and that for fingerlings was $\$ 806 /$ ha (Kolodychuk 1993). The maximum savings resulting from lake aeration appears to be only $\$ 156 / \mathrm{ha}$. The method underestimates benefits because it does not incorporate benefits associated with a year-round fishery for large trout as compared to a summer only fishery for pan-sized trout. Underestimating benefits may be an advantage because aeration projects shown to be cost-beneficial by this method will almost certainly be cost-beneficial by other methods.

In summary, the methods currently used to assess the cost-effectiveness of lake aeration projects are rather crude and need refinement. It is not known whether lake aeration creates new angling effort or merely redistributes angler effort within a region (Ashley 1987). More effort is needed to quantify important variables such as fish survival, growth, and catchability in aerated lakes, the monetary value of an angler-day, and angler responses to aeration projects. There is also a real need for a more accurate and complete recording of expenses associated with aeration projects. Many aeration projects, especially those outside Alberta, are operated by agencies such as fish and game clubs, lake associations, private companies, and municipalities. Sometimes project costs are shared between two or more agencies. Cost-benefit analysis would be facilitated if a single agency had responsibility for keeping records of all expenses incurred by aeration projects.

\subsection{Summary of Winterkill Remediation Techniques}

Lake aeration for the purpose of preventing winterkill has not received much scientific research, either within Alberta or elsewhere in North America. The major portion of lake aeration research has been directed at hypolimnetic aeration conducted for the purpose of 
improving water quality or extending summer fish habitat in deep lakes. Although a sizable literature has accumulated on compressed air systems used in winterkill lakes, it is mainly comprised of descriptive studies which document oxygen levels and fish survival in response to a single type of aeration system, usually in a single lake. These studies were not designed to elucidate the operating characteristics of aeration systems, compare the cost-effectiveness of alternative techniques, or to develop sizing methods for aeration systems. Very few studies have been conducted on mechanical surface aeration, pump and cascade aeration, or snow clearing. Consequently, much of the information presented in this review had to be obtained through consultations with system operators.

Table 6 summarizes the important features of those aeration techniques which are potentially suitable for effective winterkill remediation in Alberta. Information in Table 6 may need to be updated in the future as additional research clarifies the operating characteristics of the various aeration systems. The various types of hypolimnetic aeration (full air lift, partial airlift, deep bubble oxygen injection) were not designed nor considered suitable for cost-effective winterkill remediation.

Comparison of the capital and operating costs of alternative aeration systems is extremely useful in identifying the most economical technique for a particular situation. Making reliable cost comparisons requires that the systems being compared are properly sized to the lake and otherwise optimized (at least approximately) to function efficiently. Cost comparisons between techniques which are being used inefficiently is not very instructive. Unfortunately, the optimum operating conditions and size of suitable habitat created per unit of cost or power are not well enough defined for any aeration system to allow completely reliable cost comparisons. Minnesota appears to be the only jurisdiction having attempted a cost comparison between alternative winter lake aeration systems (Pederson 1982; Danks 1992). This was done by means of questionnaires sent to more than 200 aeration system operators in the state. The aeration systems compared were compressed air injection, mechanical surface aeration, mechanical aspirators (similar to mechanical surface aerators only they create a horizontal jet of water just below the lake surface), and pump and cascade aeration. Each of these systems was used in a wide range of lake sizes from less than 10 to hundreds or thousands of acres (Pederson 1982; Danks 1992). Only yearly operating costs were compared. All systems had power usages and costs which varied approximately two orders of magnitude between individual installations. This suggests that the 
techniques were not being used with maximum efficiency. The author (Danks 1992) concluded that the questionnaire results were inconclusive and could not be used to compare the efficiency of the various aeration techniques.

Table 7 represents an attempt to make reliable estimates of the cost saving which might be realized in Alberta from the use of pump and cascade and mechanical surface aerators rather than existing compressed air systems. Complete capital and operating costs were available for three compressed air systems in Alberta (Kolodychuk 1993). The pump and cascade systems in Manitoba were used for comparison because these systems appear to function very efficiently in preventing winterkill. Capital and operating costs for the pump and cascade systems were provided by W.N. Howard, Regional Fisheries Manager, Brandon, Manitoba. The costs of mechanical surface aeration were determined by estimating the size of surface aerator required to replace the three existing compressed air systems used for comparison. Prices of the mechanical surface aerators were obtained by contacting the supplier. Hydro costs (per kw hour per month) were calculated from information provided by Kolodychuk (1993) for the existing compressed air systems in Alberta.

The cost comparisons in Table 7, together with literature reviews and consultations, lead to the following conclusions regarding the efficiency of alternative winter lake aeration techniques. It seems fairly certain that mechanical surface aerators have lower operating costs and maintenance requirements than electrical compressed air systems. Pump and cascade systems appear to offer the most cost-effective means of averting winterkill in large lakes. Cost estimates for snow clearing were not made because these are highly dependent on snow conditions which exhibit great geographic and yearly variability. Nevertheless, snow clearing is probably not costeffective on Alberta sport fishing lakes, most of which are fairly large (> 10 acres). However, snow clearing may be cost-efficient on small farm ponds when compared to the cost of installing hydro power to operate an aeration system. 


\begin{tabular}{|c|c|c|c|c|}
\hline 总 & 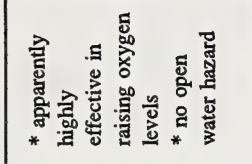 & 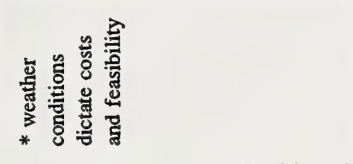 & 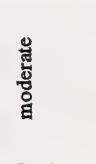 & 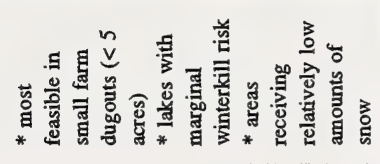 \\
\hline 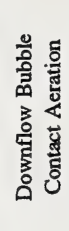 & 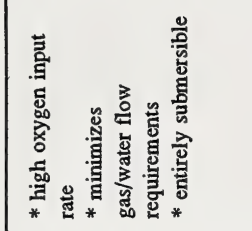 & 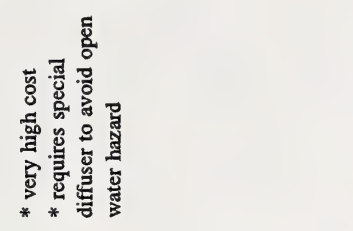 & $\begin{array}{l}\text { 品 } \\
\text { 品 }\end{array}$ & 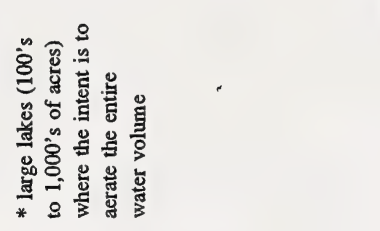 \\
\hline 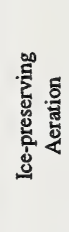 & 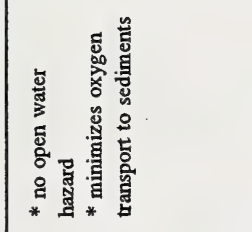 & 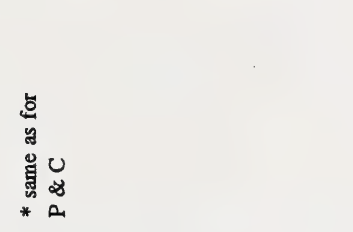 & $\begin{array}{l}: \\
\stackrel{0}{g}\end{array}$ & 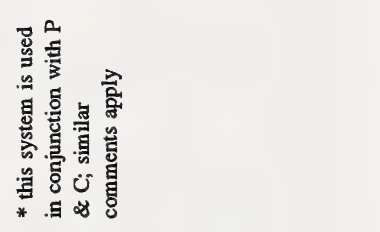 \\
\hline 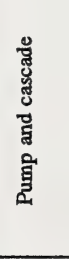 & 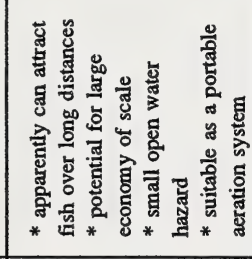 & 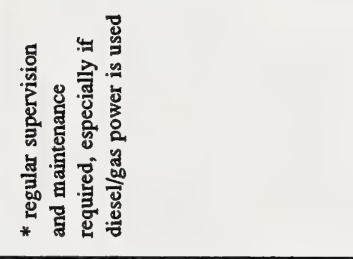 & 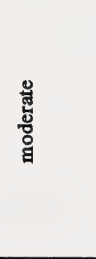 & 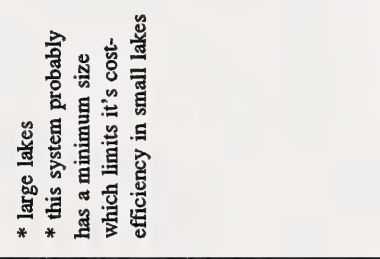 \\
\hline 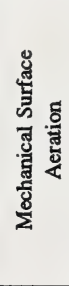 & 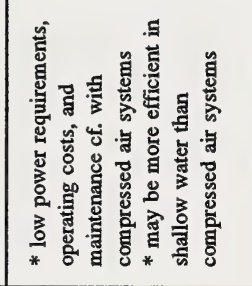 & 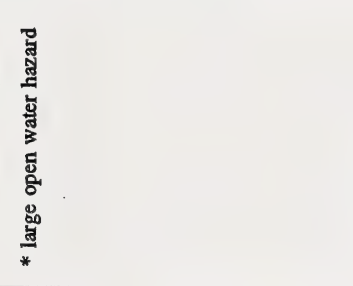 & 霓 & 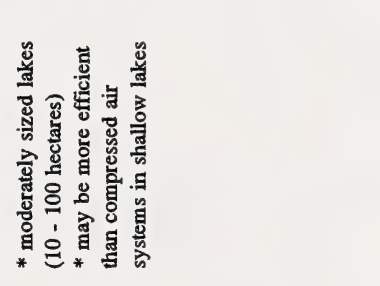 \\
\hline 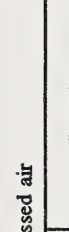 & 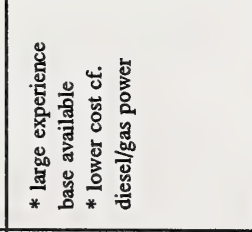 & 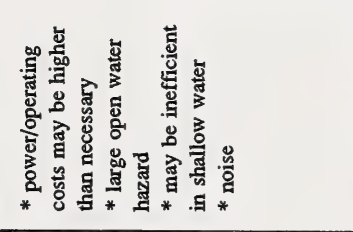 & 急 & 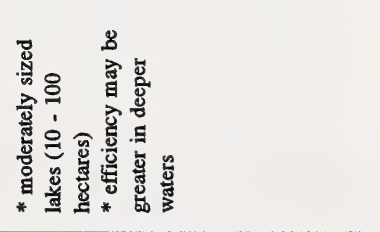 \\
\hline 总 & 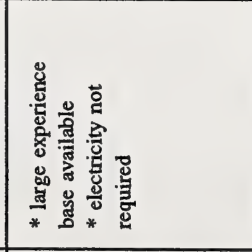 & 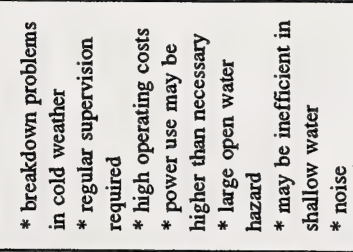 & 䨘 & 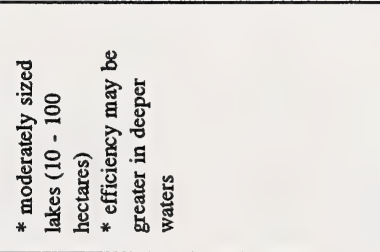 \\
\hline & 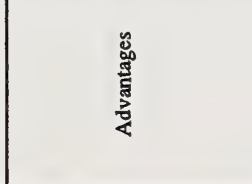 & 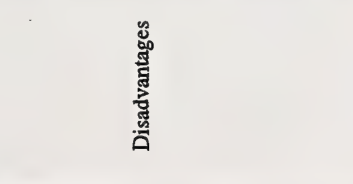 & 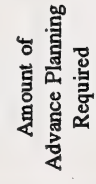 & 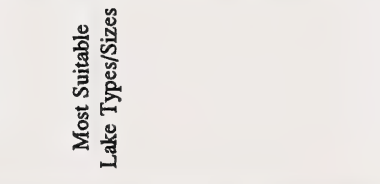 \\
\hline
\end{tabular}




\begin{tabular}{|c|c|c|c|c|c|c|c|c|c|c|}
\hline 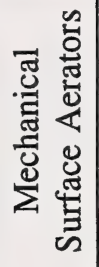 & 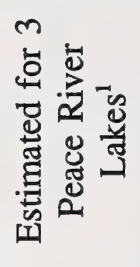 & $\frac{n}{6}$ & $\begin{array}{l}n \\
0 \\
0\end{array}$ & ' & $\begin{array}{l}8 \\
8 \\
0 \\
0 \\
0\end{array}$ & $\begin{array}{l}\text { त्र } \\
\text { m. }\end{array}$ & 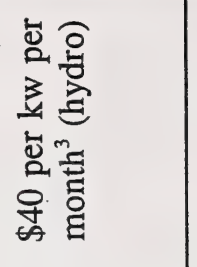 & $\underset{-}{\mathbb{S}}$ & 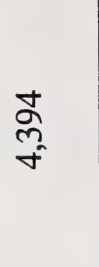 & $\vec{b}$ \\
\hline 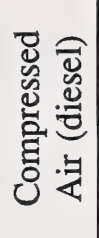 & 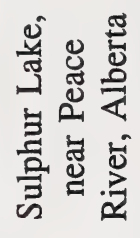 & $\bar{n}$ & $\begin{array}{l}\circ \\
0\end{array}$ & ' & $\sigma$ & 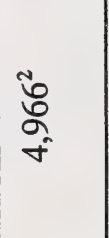 & 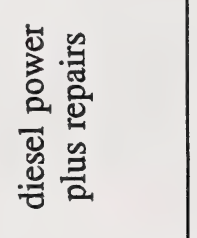 & 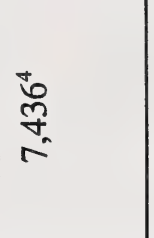 & $\begin{array}{l}\text { ơ } \\
\text { d } \\
\text { đ }\end{array}$ & 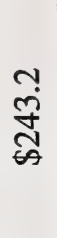 \\
\hline 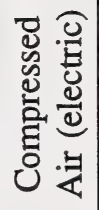 & 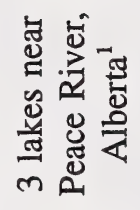 & $\frac{n}{6}$ & $\stackrel{n}{\sim}$ & ' & $\sigma$ & $\begin{array}{c}\text { న్ } \\
\infty \\
\text { i }\end{array}$ & 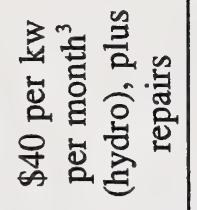 & 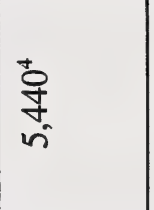 & ભ్ & $\stackrel{n}{\stackrel{n}{\pi}}$ \\
\hline 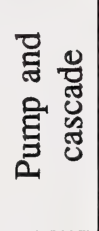 & 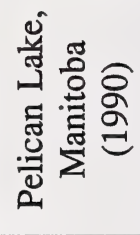 & $\begin{array}{l}\text { ¿ु } \\
\text { ले }\end{array}$ & $\begin{array}{l}0 \\
\underset{x}{\sim} \\
\sim\end{array}$ & 올 & $\begin{array}{l}8 \\
8 \\
0 \\
0 \\
\text { n. }\end{array}$ & $\underset{\delta}{8}$ & 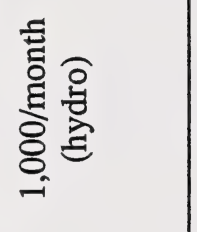 & ठ্ণ & $\begin{array}{l}8 \\
8 \\
\text { ㄱ. }\end{array}$ & $\begin{array}{l}\text { న్ } \\
\text { ભે }\end{array}$ \\
\hline 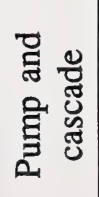 & 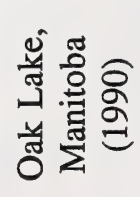 & $\begin{array}{l}\text { నू } \\
\text { ন }\end{array}$ & 으 & $\stackrel{\wp}{=}$ & $\begin{array}{l}8 \\
n^{2} \\
6 \\
-1\end{array}$ & $\begin{array}{l}\text { \&్ల } \\
\text { m. }\end{array}$ & 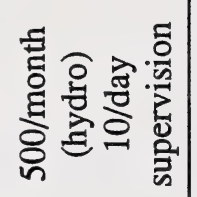 & \begin{tabular}{l}
8 \\
$\infty$ \\
\multirow{+}{*}{}
\end{tabular} & $\underset{\infty}{\stackrel{8}{\infty}}$ & $\underset{\approx}{\tilde{N}}$ \\
\hline 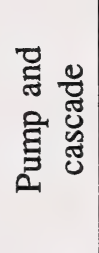 & 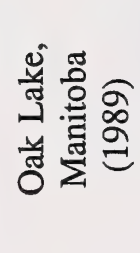 & নু & ్ా & 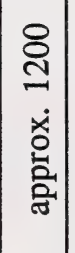 & $\begin{array}{l}8 \\
n \\
n \\
n\end{array}$ & $\underset{r}{\stackrel{8}{r}}$ & 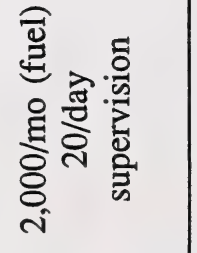 & $\begin{array}{l}8 \\
8 \\
\curvearrowleft \\
\sim\end{array}$ & 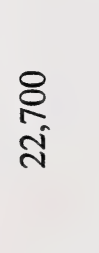 & กิ \\
\hline 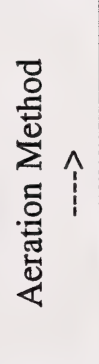 & $\stackrel{\triangleq}{\mathscr{H}} \hat{i}$ & 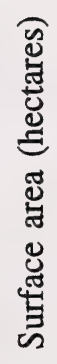 & 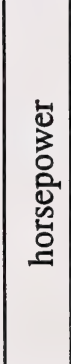 & 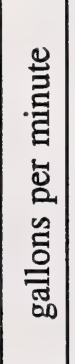 & 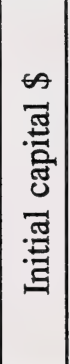 & 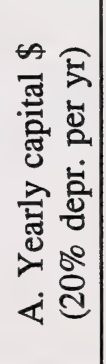 & 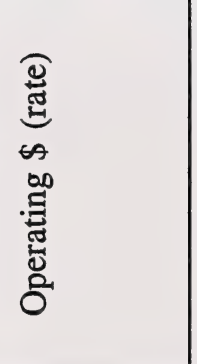 & 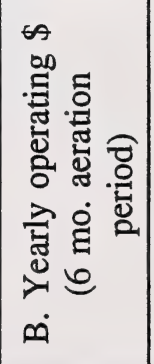 & 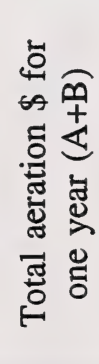 & 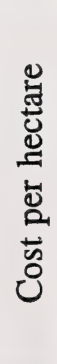 \\
\hline
\end{tabular}


Footnotes to Table 7

1. Costs are calculated for E. Dollar, Figure Eight, and Cummings lakes for 1991-92. Moonshine, Poirier, and Zama lakes were not included because much of their costs are paid by other agencies and not available.

2. Amortized capital costs. Includes costs of shed, compressor unit, hose, and diffuser most of which are amortized at $20 \%$ per year. Costs of installing hydro power are excluded.

3. Hydro costs are average rates for electrical aeration systems in Peace River. Calculated from Ed Kolodychuk's 1991-92 report.

4. Includes only power and repairs to equipment. Manpower, mileage, and miscellaneous costs in 1991-92 amount to $\$ 872$ for the three electrical systems in Peace River and $\$ 1,918$ for Sulphur Lake.

5. Based on $1 \mathrm{hp}$ aerator for E. Dollar L., one $2 \mathrm{hp}$ and one $1 \mathrm{hp}$ units for Figure Eight L., and two $1 \mathrm{hp}$ units for Cummings $\mathrm{L}$.

6. Price quotes from supplier (Arbrux Limited, Uxbridge, Ontario).

7. Calculated assuming $\$ 40 / \mathrm{kw} /$ month for hydro costs and no maintenance required. $6 \mathrm{hp}$ $=4.47 \mathrm{kw}$ 
1. Mechanical surface aerators should be considered for future aeration installations. If the results from these installations are positive, then the replacement of existing compressed air systems with mechanical aerators should be considered. In British Columbia, mechanical surface aerators have substantially lower maintenance and operating costs compared to compressed air systems. Weather conditions and other characteristics of British Columbia winterkill lakes appear sufficiently similar to those in Alberta to warrant trials with mechanical surface aeration.

2. The legal aspects and other implications created by the open water hazard at winter lake aeration sites should be investigated. Although appropriate warning measures may fulfil the government's legal responsibilities, all reasonable measures should be taken to minimize the safety hazard created by winter lake aeration.

3. The accounting procedures used to record expenses incurred by lake aeration projects need improvement. This applies especially to situations in which non-government agencies cover all or part of the project cost. Accurate record-keeping not only facilitates reliable cost-benefit analysis but also helps to identify ways of reducing lake aeration costs.

4. Major lake aeration programs in the province should have a research component. This is necessary so that improvements in aeration methodology can be properly tested, documented, and transferred to other regions.

\section{RESEARCH RECOMMENDATIONS}

1. A priority for research should be to compare the operating characteristics, zone of influence, and cost-efficiency of alternative aeration systems. Parameters which should be measured include oxygen dispersal dynamics, water flow patterns, and fish attraction and behavioural responses to aeration. The aeration techniques to be compared should include compressed air injection, mechanical surface aeration, and pump and cascade aeration. Snow clearing should be investigated as a cost-effective means of averting winterkill in small ponds. This type of research should be directed at identifying the advantages and disadvantages of the various aeration methods, the amount of suitable fish 
habitat created per unit of aeration effort, and the situations/lake characteristics for which each system is best suited.

2. Reliable models for predicting the amount of suitable habitat created by lake aeration systems are needed. It is suggested that studies by Rogers (1992) on winter heat budgets and Schladow $(1992,1993)$ on bubble plume dynamics might serve as the basis for these models. Field studies will also be required to identify the factors which determine the number of fish which can be attracted to and successfully over-wintered within the oxygenated habitat created by aeration systems.

3. Studies designed to identify salmonid gamefish that are potentially more resistant to hypoxia than rainbow trout have the potential to minimize the need for artificial aeration and to reduce the severity of winterkill on a province-wide scale. This research should begin with laboratory studies to compare the winter oxygen requirements of the salmonid gamefish which are potentially suitable for stocking in winterkill lakes (rainbow trout, brook trout, Arctic grayling, and brown trout).

4. There is a need to quantify the major processes which determine winter oxygen depletion rates. Those processes include oxygen consumption by the sediments and water column, the decay of macrophytes and phytoplankton, chemical oxygen demand, under-ice photosynthesis, and respiration by fish and other multicellular organisms. The lake characteristics which promote under-ice photosynthesis also need study. This research would serve two purposes: a) to characterize lakes according to the type and level of remediation necessary to mitigate winterkill and b) to identify ways to minimize the increase in lake oxygen demand induced by aeration practices.

5. There is a need for improved quantification of fishery statistics in winterkill lakes and angler responses to lake aeration. Important fishery statistics include fish density, survival rates, growth rates, and catchability. Angler response includes the level of angling effort, catch per unit effort, and the value of an angler-day. To measure these variables, it may be necessary to first develop efficient sampling methods for small lakes, as was the case in British Columbia. This type of research is necessary for reliable cost-benefit analysis and will also help to determine the total number and biomass of fish which can be overwintered for a unit cost of aeration. 
Adams, W.A. 1978. Effects of ice cover on the solar radiation regime in Canadian lakes. Verhandlungen der Internationalen Vereinigung fuer Theoretische und Angewandte Limnologie. 20:141-149.

Adelman, I.R., and L.L. Smith. 1970. Effect of hydrogen sulfide on northern pike eggs and sac fry. Transactions of the American Fisheries Society. 99:501-509.

Alabaster, J.S., and D.W.M. Herbert. 1954. Influence of carbon dioxide on the toxicity of ammonia. Nature. 174:404.

Alabaster, J.S., D.G. Shurben, and G. Knowles. 1979. The effect of dissolved oxygen and salinity on the toxicity of ammonia to smolts of salmon, Salmo salar L. Journal of Fish Biology. 15:705-712.

Ashley, K.I. 1985. Hypolimnetic aeration: practical design and application. Water Research. 19:735-740.

Ashley, K.İ. 1987. Artificial circulation in British Columbia: Review and evaluation. British Columbia Fisheries Branch Technical Circular No. 78, 34 pages.

Ashley, K.I. 1990. Preliminary design for a hypolimnetic aeration system for Newman Lake. Washington State University Contract No. 10004. 30 pages.

Ashley, K.I., S. Hay, and G.H. Scholten. 1987. Hypolimnetic aeration: field test of the empirical sizing method. Water Research. 21:223-227.

Ashley, K.I., K. Tsumura, and B. M. Chan. 1992. Fisheries management of winterkill lakes in southern interior British Columbia. In: Aquatic ecosystems in semi-arid regions: implications for resource management. R.D. Robarts and M.L. Bothwell (eds). N.H.R.I. symposium series 7, Environment Canada, Saskatoon. pages 287-297.

Babin, J., and E.E. Prepas. 1985. Modelling winter oxygen depletion rates in ice-covered temperate zone lakes in Canada. Canadian Journal of Fisheries and Aquatic Sciences. 42:239-249.

Bandow, F. 1986. Evaluation of winter lake aeration techniques in Minnesota. Minnesota Department of Natural Resources, Division of Fish and Wildlife, Section of Fisheries. Investigational Report No. 386. 48 pages.

Banks, R.B., and F.F. Herrera. 1977. Effect of wind and rain on surface reaeration. Journal of the Environmental Engineering Division, American Society of Civil Engineers. 103:489504. 
Barica, J., J. Gibson, and W. Howard. 1983. Feasibility of snow clearing to improve dissolved oxygen conditions in a winterkill lake. Canadian Journal of Fisheries and Aquatic Sciences. 40:1526-1531.

Barica, J., and J.A. Mathias. 1979. Oxygen depletion and winterkill in small prairie lakes under extended ice cover. Journal of the Fisheries Research Board of Canada. 36:980-986.

Basu, S.P. 1959. Active respiration of fish in relation to ambient concentrations of oxygen and carbon dioxide. Journal of the Fisheries Research Board of Canada. 16:175-212.

Belanger, T.V. 1981. Benthic oxygen demand in Lake Apopka, Florida. Water Research. 15:267274.

Bennett, G.W. 1948. Lake management reports. 5. Winterkill of fishes in an Illinois lake. Illinois Natural History Survey. Biological Notes No. 19. 9 pages.

Berg, R.J., and J.J. Magnuson. 1970. Variability of winterkill survival in fishes. University of Wisconsin, Water Resources Centre. Technical Report W70-09671. 40 pages.

Bidgood, B.F. 1967. An attempt to reduce winter oxygen depletion in Half Moon Lake. Alberta Department of Lands and Forests, Fish and Wildlife Division. 9 pages.

Black, E.C. 1940. The transport of oxygen by the blood of freshwater fish. Biological Bulletin. 79:215-229.

Bolsenga, S.J. 1969. Total albedo of Great Lakes ice. Water Resources Research. 5:1132-1133.

Bolsenga, S.J. 1983. Spectral reflectances of snow and fresh-water ice from 340 through 1100 nm. Journal of Glaciology. 29:296-305.

Boynton, W.R, W.M. Kemp, C.G. Osborne, K.R. Kaymeyer, and M.C. Jenkins. 1981. Influence of water circulation rate on in situ measurements of benthic community respiration. Marine Biology 65:185-190.

Brewer, W.S., A.R. Abernathy, and M.J.B. Paynter. 1977. Oxygen consumption by freshwater sediments. Water Research 11:471-473.

Brown, V.M. 1968. The calculation of the acute toxicity of mixtures of poisons to rainbow trout. Water Research. 2:723-733

Burrows, R.E. 1964. Effects of accumulated excretory products on hatchery-reared salmonids. United States Fish and Wildlife Service. Research Report No. 66. 12 pages.

Casselman, J.M., and H.H. Harvey. 1975. Selective fish mortality resulting from low winter oxygen. Verhandlungen der Internationalen Vereinigung fuer Theoretische und Angewandte Limnologie. 19:2418-2429. 
Chapman, W.M. 1939. Effects of a decreased oxygen supply on sockeye and chinook salmon. Transactions of the American Fisheries Society. 69:197-204.

Charlton, M.N. 1980. Hypolimnion oxygen consumption in lakes: discussion of productivity and morphometry effects. Canadian Journal of Fisheries and Aquatic Sciences. 37:1531-1539.

Colby, P.J., and L.L. Smith. 1967. Survival of walleye eggs and fry on paper fiber sludge deposits in Rainy River, Minnesota. Transactions of the American Fisheries Society. 96:278-296.

Cooper, G.P., and C.N. Washburn. 1946. Relation of dissolved oxygen to winter mortality of fish in Michigan lakes. Transactions of the American Fisheries Society. 76:23-33.

Danks, M. 1992. Aeration permit program annual report. Minnesota Department of Natural Resources, Division of Fish and Wildlife, Ecological Services Section. 38 pages.

Davis, J.C. 1975. Minimal dissolved oxygen requirements of aquatic life with emphasis on Canadian species: a review. Journal of the Fisheries Research Board of Canada. 32(12):2295-2332.

Davison, R.C., W.P. Breese, C.E. Warren, and P. Doudoroff. 1959. Experiments on the dissolved oxygen requirements of cold-water fishes. Sewage and Industrial Wastes. 31:950-966.

Dinsmore, W.P., and E.E. Prepas. 1993. Changes in profundal macroinvertebrate diversity in a deep eutrophic lake undergoing hypolimnetic oxygen injection, with particular reference to Chironomus spp. (Chironomidae). Verhandlungen der Internationalen Vereinigung fuer Theoretische und Angewandte Limnologie. 25:302-306.

Doudoroff, P., and D.L. Shumway. 1970. Dissolved oxygen requirements of freshwater fishes. Food and Agriculture Organization of the United Nations. Fisheries Technical Paper No. 86. 291 pages.

Downing, K.M., and J.C. Merkens. 1955. The influence of dissolved-oxygen concentration on the toxicity of un-ionized ammonia to rainbow trout (Salmo gairdneri Richardson). Annals of Applied Biology. 43:243-246.

Ellis, C.R., and H.G. Stefan. 1989. Oxygen demand in ice covered lakes as it pertains to winter aeration. Water Resources Bulletin. 25:1169-1175.

Ellis, C.R., and H.G. Stefan. 1990. Hydraulic design of winter lake aeration system. Journal of Environmental Engineering. 116:376-391.

Ellis, C.R., and Stefan, H.G. 1991a. Field testing of an ice-preserving winter lake aeration system. Water Resources Bulletin. 27:903-914. 
Ellis, C.R., and Stefan, H.G. 1991b. Hydraulic design of an axisymmetric diffuser for a lake aeration system. University of Minnesota, St. Anthony Falls Hydraulic Laboratory. External Memorandum No. M-223. 41 pages.

Environmental Protection Agency (U.S. E.P.A.) 1989. Design manual -fine pore aeration systems. U.S. E.P.A. report 625/1-89/023. 305 pages.

European Inland Fisheries Advisory Commission Working Party on Water Quality Criteria for European Freshwater Fish (E.I.F.A.C.). 1973. Water quality criteria for European freshwater fish: report on ammonia and inland fisheries. Water Research. 7:1011-1022.

Fast, A.W. 1973. Effects of artificial hypolimnion aeration on rainbow trout (Salmo gairdneri Richardson) depth distribution. Transactions of the American Fisheries Society. 4:715-721.

Fast, A.W. 1978. Artificial aeration as a lake restoration technique. Proceedings of a National Conference on Lake Restoration, Minneapolis, Minnesota, August 22-24, 1978. pages 121-131.

Fast, A.W. 1994. Winterkill prevention in lakes and ponds using artificial aeration. Reviews in Fisheries Science. 2:23-77.

Fast, A.W., and M.W. Lorenzen. 1976. Synoptic survey of hypolimnetic aeration. Journal of the Environmental Engineering Division, American Society of Civil Engineers. 102:11611173.

Fast, A.W., Lorenzen, M.W., and J.H. Glenn. 1976. Comparative study with costs of hypolimnetic aeration. Journal of the Environmental Engineering Division, American Society of Civil Engineers. 102:1175-1187.

Feldmeth, C.R. and C.H. Eriksen. 1978. A hypothesis to explain the distribution of native trout in a drainage of Montana's Big Hole River. Verhandlungen der Internationalen Vereinigung fuer Theoretische und Angewandte Limnologie. 20:2040-2044.

Fry, F.E. 1939. The position of fish and other higher animals in the economy of lakes. American Association for the Advancement of Science. Publication No. 10, pages 132-142.

Fry, F.E. 1947. Effects of the environment on animal activity. University of Toronto Biological Series No. 55; Ontario Fish Research Laboratory Publication No. 68. 62 pages.

Fry, F.E., V.S. Black, and E.C. Black. 1947. Influence of temperature on the asphyxiation of young goldfish (Carassius auratus L.) under various tensions of oxygen and carbon dioxide. Biological Bulletin. 92:217-224.

Funk, W.H., B.C. Moore, S.K. Burkett, and S.T.J. Juul. 1994. Newman Lake Restoration Phase II. State of Washington Water Research Center, Washington State University, Report 87. 155 pages. 
Gebhart, G.E., and R.C. Summerfelt. 1978. Seasonal growth rates of fishes in relation to conditions of lake stratification. Proceedings of the Oklahoma Academy of Science. 58:610.

Gee, J.H., R.F. Tallman, and H.J. Smart. 1978. Reactions of some great plains fishes to progressive hypoxia. Canadian Journal of Zoology. 56:1962-1966.

Graham, D.S. 1980. Destratification of lakes using bubble columns, discussion. Journal of the Hydraulics Division, American Society of Civil Engineers. 106:1129-1132.

Graham, J.M. 1949. Some effects of temperature and oxygen pressure on the metabolism and activity of the speckled trout. Canadian Journal of Research. Section D. 27:270-287.

Graneli, W. 1978. Sediment oxygen uptake in south Swedish lakes. Oikos (Copenhagen) 30:7-16.

Greenbank, J. 1945 Limnological conditions in ice-covered lakes, especially as related to winterkill of fish. Ecological Monographs. 15(04):344-392.

Grenfell, T.C., and G.A. Maykut. 1977. The optical properties of ice and snow in the Arctic Basin. Journal of Glaciology. 18:445-463.

Guenther, P.M., and W.A. Hubert. 1991. Factors influencing dissolved oxygen concentrations during winter in small Wyoming reservoirs. Great Basin Naturalist 51:282-285.

Gutsell, J.S. 1929. Influence of certain water conditions, especially dissolved gasses, on trout. Ecology. 5(1):77-94.

Hargrave, B.T. 1969. Similarity of oxygen uptake by benthic communities. Limnology and Oceanography. 14:801-805.

Hargrave, B.T. 1972a. A comparison of sediment oxygen uptake, hypolimnetic oxygen deficit and primary production in Lake Esrom, Denmark. Verhandlungen der Internationalen Vereinigung fuer Theoretische und Angewandte Limnologie. 18:134-139.

Hargrave, B.T. 1972b. Oxidation-reduction potentials, oxygen concentration and oxygen uptake of profundal sediments in a eutrophic lake. Okios. 23:166-177.

Hess, L. 1975. The effect of the first year of artificial hypolimnion aeration on oxygen, temperature, and depth distribution of rainbow trout (Salmo gairdneri Richardson) in Spruce Knob Lake. Proceedings of the West Virginia Academy of Science. 47:176-182.

Hogan, W.T., Reed, F.E., and A.W. Starbird. 1970. Optimum mechanical aeration systems for rivers and ponds. U.S. E.P.A. report 16080D000.

Hunt, C. 1967. Artificial circulation experiment at Little Chickakoo Lake. Alberta Department of Lands and Forests, Fish and Wildlife Division. 9 pages. 
Hutchinson, G.E. 1957. A treatise on limnology. I. geography, physics, and chemistry. John Wiley and Sons Inc., New York, N.Y. 1015 pages.

Irving, L., E.C. Black, and V. Safford. 1939. The respiratory tolerance of some Pennsylvania fish. American Journal of Physiology. 126:545-546.

Jackson, M.B., and D.C. Lasenby. 1982. A method for predicting winter oxygen profiles in icecovered Ontario lakes. Canadian Journal of Fisheries and Aquatic Sciences. 39:1267-1272.

Jansen, W.A., and W.C. Mackay. 1991. Body composition and reproductive investment of stunted yellow perch, Perca flavescens. Verhandlungen der Internationalen Vereinigung fuer Theoretische und Angewandte Limnologie. 24:2356-2361.

Johnson, T.B., and D.O. Evans. 1990. Size-dependent winter mortality of young-of-the-year white perch: climate warming and invasion of the Laurentian Great Lakes. Transactions of the American Fisheries Society. 119:301-313.

Johnson, T.B., and D.O. Evans. 1991. Behaviour, energetics and associated mortality of youngof-year white perch (Morone americana) and yellow perch (Perca flavescens) under simulated winter conditions. Canadian Journal of Fisheries and Aquatic Sciences. 48:672680.

Johnson, F.H., and J.B. Moyle. 1969. Management of a large shallow winterkill lake in Minnesota for the production of pike (Esox lucius). Transactions of the American Fisheries Society. 4:691-697.

Jorgensen, B.B., and N.P. Revsbech. 1985. Diffusive boundary layers and the oxygen uptake of sediments and detritus. Limnology and Oceanography. 30:111-122.

Kelly, C.A., and D.P. Chynoweth. 1980. Comparison of in situ and in vitro rates of methane release in freshwater sediments. Applied and Environmental Microbiology. 40:287-293.

Klinger, S.A., J.J. Magnuson, and G.W. Gallepp. 1982. Survival mechanisms of the central mudminnow (Umbra limi), fathead minnow (Pimephales promelas), and brook stickleback (Culaea inconstans) for low oxygen in winter. Environmental Biology of Fishes. 7:113120.

Knowles, R., and D.R.S. Lean. 1987. Nitrification: a significant cause of oxygen depletion under winter ice. Canadian Journal of Fisheries and Aquatic Sciences. 44:743-749.

Kobus, H.E. 1968. Analysis of the flow induced by air-bubble systems. In: Proceedings of the Eleventh Conference on Coastal Engineering, London.

Kolodychuk, E. 1993. Results and cost effectiveness of seven aeration systems used in the Peace River Region 1991-92. Alberta Fish and Wildlife Division. 32 pages. 
Kranenburg, C. 1979. Destratification of lakes using bubble columns. Journal of the Hydraulics Division, American Society of Civil Engineers. 105:333-349.

Linsey, G.A., and D.C. Lasenby. 1985. Comparison of summer and winter oxygen consumption rates in a temperate dimictic lake. Canadian Journal of Fisheries and Aquatic Sciences. 42:1634-1639.

Lloyd, R., and D.W.M. Herbert. 1960. The influence of carbon dioxide on the toxicity of unionized ammonia to rainbow trout (Salmo gairdneri Richardson). Annals of Applied Biology. 48:399-404.

Lonnerblad, G. 1930. Uber die sauerstoffabsorption des bodensubstrates in einigen seetypen. Botaniska Notiser. 1930:53-60.

Lorenzen, M.W. 1977. Aeration/circulation keeps algal blooms in check/2. Water and Wastes Engineering 14:88-92.

Lorenzen, M., and A. Fast. 1977. A guide to aeration/circulation techniques for lake management. Corvallis Environmental Research Laboratory, U.S. E.P.A. report No. EPA-600/3-77-004. 125 pages.

Magnuson, J.J., A. L. Beckel, K. Mills, and S. B. Brandt. 1985. Surviving winter hypoxia: behavioural adaptations of fishes in a northern Wisconsin lake. Environmental Biology of Fishes. 14:241-250.

Magnuson, J.J., L.B. Crowder, and P.A. Medvick. 1979. Temperature as an ecological resource. American Zoologist. 19:331-343.

Magnuson, J.J., and D.J. Karlen. 1970. Visual observation of fish beneath the ice in a winterkill lake. Journal of the Fisheries Research Board of Canada. 27:1059-1068.

Mathias, J.A., and J. Barica. 1980. Factors controlling oxygen depletion in ice-covered lakes. Canadian Journal of Fisheries and Aquatic Sciences. 37:185-194.

Mattingly, G.E. 1977. Experimental study of wind effects on reaeration. Journal of the Hydraulics Division, American Society of Civil Engineers. 103:311-323.

McDonnell, A.J., and S.D. Hall. 1969. Effects of environmental factors on benthal oxygen uptake. Journal of the Water Pollution Control Federation. 41:R353-R363.

Merkens, J.C., and K.M. Downing. 1957. The effect of tension of dissolved oxygen on the toxicity of un-ionized ammonia to several species of fish. Annals of Applied Biology. 45:521-527.

Miller, L.G., and R.S. Oremland. 1988. Methane efflux from the pelagic regions of four lakes. Global Biogeochemical Cycles. 2(3):269-277. 
Moore, W.G. 1942. Field studies on the oxygen requirements of certain fresh-water fishes. Ecology. 23:319-329.

Mosher, T.D. 1983. Effects of artificial circulation on fish distribution and angling success for channel catfish in a small prairie lake. North American Journal of Fisheries Management. 3:403-409.

Muller, H. 1957. Untersuchung der sauerstoffverhaltnisse unter eis. Zeitschrift fuer Fischerei und Deren Hilfswissenschaften. 6:316-322.

Neilson, B.J. 1974. Reaeration dynamics of reservoir destratification. Journal of the American Water Works Association. 66:617-620.

Nelson, J.S., and M.J. Paetz. 1992. The fishes of Alberta, $2^{\text {nd }}$ edition. University of Alberta Press. University of Calgary Press. 437 pages.

Overholtz, W.J., A.W. Fast., R.A. Tubb, and R. Miller. 1977. Hypolimnion oxygenation and its effects on the depth distribution of rainbow trout (Salmo gairdneri) and gizzard shad (Dorosoma cepedianum). Transactions of the American Fisheries Society. 106(04):371375.

Parkinson, E.A., J. Berkowitz, and C.J. Bull. 1988. Sample size requirements for detecting changes in some fisheries statistics from small trout lakes. North American Journal of Fisheries Management. 8:181-190.

Paulin, L. 1960. Snow removal heads off winterkill. Wisconsin Conservation Bulletin. 25:24-25.

Pederson, D.W. 1982. Aeration and mixing systems in Minnesota lakes. Minnesota Department of Natural Resources, Division of Fish and Wildlife, Ecological Services Section. Special Publication No. 133. 29 pages.

Petrosky, B.R., and J.J. Magnuson. 1973. Behavioural responses of northern pike, yellow perch, and bluegill to oxygen concentrations under simulated winterkill conditions. Copeia. 1973:124-133.

Philipp, D.P., and G.S. Whitt. 1991. Survival and growth of northern, Florida, and reciprocal $F_{1}$ hybrid largemouth bass in central Illinois. Transactions of the American Fisheries Society. 120:58-64.

Post, J.R., and D.O. Evans. 1989. Size-dependent overwinter mortality of young-of-the-year yellow perch (Perca flavescens): laboratory, in situ enclosure, and field experiments. Canadian Journal of Fisheries and Aquatic Sciences. 46:1958-1968.

Prepas, E.E., D.J. Webb, C.L.K. Robinson, and T.P. Murphy. 1990. Impact of liquid oxygen injection on a deep, naturally eutrophic lake: Amisk Lake, Alberta, year one. Verhandlungen der Internationalen Vereinigung fuer Theoretische und Angewandte Limnologie. 24:320. 
Prowse, T.D., and R.L. Stephenson. 1986. The relationship between winter lake cover, radiation receipts, and the oxygen deficit in temperate lakes. Atmosphere-Ocean. 24:386-403.

Reid Crowther \& Partners Ltd. 1992. A report on fine bubble aeration tubing. Prepared for Municipal Branch, Alberta Environment.

Richey, E.P., and C.K. Sollitt. 1970. Pneumatic destratification of density layers. Fisheries Research Papers, Washington Department of Fisheries. 3:37-52.

Ricker, W.E. 1949. Effects of removal of fins upon the growth and survival of spiny-rayed fishes. Journal of Wildlife Management. 13:29-40.

Rogers, C.K. 1992. Impact of an artificial circulation device on the heat budget of an ice-covered mid-latitude lake. M.Sc. Thesis. University of British Columbia, Department of Civil Engineering. 173 pages.

Rudd, J.W.M., and R.D. Hamilton. 1975. Factors controlling rates of methane oxidation and the distribution of the methane oxidizers in a small stratified lake. Archiv fuer Hydrobiologie. 75:522-538.

Rudstam, L.G., and J.J. Magnuson. 1985. Predicting the vertical distribution of fish populations: analysis of cisco, Coregonus artedii, and yellow perch, Perca flavescens. Canadian Journal of Fisheries and Aquatic Sciences. 42:1178-1188.

Schindler, D.W. 1971. A hypothesis to explain differences and similarities among lakes in the experimental lakes area, northwestern Ontario. Journal of the Fisheries Research Board of Canada. 28:295-301.

Schladow, S.G. 1992. Bubble plume dynamics in a stratified medium and implications for water quality amelioration in lakes. Water Resources Research 28:313-321.

Schladow, S.G. 1993. Lake destratification by bubble-plume systems: design methodology. Journal of Hydraulic Engineering 119:350-368.

Scidmore, W.J. 1957. An investigation of carbon dioxide, ammonia, and hydrogen sulfide as factors contributing to fish kills in ice-covered lakes. Progressive Fish-Culturist. 19:124127.

Serns, S.L. 1976. Movement of rainbow trout across a metalimnion deficient in dissolved oxygen. Progressive Fish-Culturist 38:54.

Shepard, M.P. 1955. Resistance and tolerance of young speckled trout (Salvelinus fontinalis) to oxygen lack, with special reference to low oxygen acclimation. Journal of the Fisheries Research Board of Canada. 12(3):387-446.

Smith, S.A., D.R. Knauer, and T.L. Wirth. 1975. Aeration as a lake management technique. Wisconsin Department of Natural Resources. Technical Bulletin No. 87. 39 pages. 
Smith, L.L., and D.M. Oseid. 1973. Effect of hydrogen sulfide on development and survival of eight freshwater fish species. In: Proceedings of an international symposium on the early life history of fish. Oban, Scotland, May 1973. pages 417-430.

Soltero, R. A., L.M. Sexton, K.I. Ashley, and K.O. McKee. 1994. Partial and full lift hypolimnetic aeration of Medical Lake, Washington to improve water quality. Water Research, in press

Somers, J.D. and J.W. Moore. 1993. Hypoxic tolerance of three fish species to low dissolved oxygen concentrations at different water temperatures. Aquatic Ecology Branch, Alberta Environmental Centre. 18 pages.

Speece, R.E. 1971. Hypolimnion aeration. Journal of the American Water Works Association. 63:6-9.

Speece, R.E. 1974. Ten years experience of reservoir aeration: reply to H. Bernhardt. Progress in Water Technology. 7:483-495.

Speece, R.E., M. Madrid, and K. Needham. 1971. Downflow bubble contact aeration. Journal of the Sanitary Engineering Division, Proceedings of the American Society of Civil Engineers. 97:433-441.

Speece, R.E., F. Rayyan, and G. Murfee. 1973a. Hypolimnion aeration with commercial oxygen. Vol. I - dynamics of bubble plume. U.S. E.P.A. Technology Series, report EPA-660/2-73025a. 184 pages.

Speece, R.E., F. Rayyan, and G. Murfee. 1973b. Hypolimnion aeration with commercial oxygen. Vol. II - bubble plume gas transfer. U.S. E.P.A. Technology Series, report EPA-660/2-73025b. 150 pages.

Taggart, C.T., and D.J. McQueen. 1982. A model for the design of hypolimnetic aerators. Water Research. 16:949-956.

Tanasichuk, R.W., and W.C. Mackay. 1989. Quantitative and qualitative characteristics of somatic and gonadal growth of yellow perch (Perca flavescens) from Lac Ste. Anne, Alberta. Canadian Journal of Fisheries and Aquatic Sciences. 46:989-994.

Thomas, C.W. 1963. On the transfer of visible radiation through sea ice and snow. Journal of Glaciology. 4:481-484.

Thurston, R.V., G.R. Phillips, and R.C. Russo. 1981. Increased toxicity of ammonia to rainbow trout (Salmo gairdneri) resulting from reduced concentrations of dissolved oxygen. Canadian Journal of Fisheries and Aquatic Sciences. 38:983-988.

Torrest, R.S., and J. Wen. 1976. Mixing and circulation of lakes and reservoirs with air plumes. University of New Hampshire Water Resource Research Center, Durham. Research Report No. 13. 128 pages 
Trimbee, A.M., and E.E. Prepas. 1988. The effect of oxygen depletion on the timing and magnitude of blue-green algal blooms. Verhandlungen der Internationalen Vereinigung fuer Theoretische und Angewandte Limnologie. 23:220-226.

Trussell, R.P. 1972. The percent un-ionized ammonia in aqueous ammonia solutions at different pH levels and temperatures. Journal of the Fisheries Research Board of Canada. 29:15051507.

Vigil, H. 1992. Literature review of sediment oxygen demand and nutrient flux measurement techniques. In: Proceedings, U.S. Army Corps of Engineers Workshop on Sediment Oxygen Demand. Providence, Rhode Island, 21-22 August 1990. Final Report June 1992. C. Cerco, D. Gunnison, and C.B. Price (eds.). pages 4-32.

Welch, H.E. 1974. Metabolic rates of arctic lakes. Limnology and Oceanography 19(1):65-73.

Welch, H.E., and M.A. Bergmann. 1985. Winter respiration of lakes at Saqvajuac, N.W.T.. Canadian Journal of Fisheries and Aquatic Sciences. 42:518-528.

Welch, H.E., P.J. Dillon, and A. Sreedharan. 1976. Factors affecting winter respiration in Ontario lakes. Journal of the Fisheries Research Board of Canada. 33:1809-1815.

Wetzel, R.G. 1975. Limnology. W.B. Saunders Company. Philadelphia, London, Toronto. 743 pages.

Wilding, J.L. 1939. The oxygen threshold for three species of fish. Ecology. 20:253-263.

Wilson, J.O., P.M. Crill, K.B. Bartlett, D.I. Sebacher, R.C. Harriss, and R.L. Sass. 1989. Seasonal variation of methane emissions from a temperate swamp. Biogeochemistry. 8:55-71.

Wirth, T.L. 1970. Mixing and aeration systems in Wisconsin lakes. In: A symposium on the management of midwestern winterkill lakes. American Fisheries Society Special Publication. E. Schneberger (ed.). Reprinted in 1974 with corrections by the Wisconsin Department of Natural Resources, Box 450, Madison, Wisconsin 53701.

Wirth, T.L. 1988. Lake aeration in Wisconsin lakes. Wisconsin Department of Natural Resources. Publication WR-196-88. 76 pages.

Wirth, T.L., D.R. Knauer, and S.A. Smith. 1975. Total and hypolimnetic aeration of lakes in Wisconsin. Verhandlungen der Internationalen Vereinigung fuer Theoretische und Angewandte Limnologie. 19:1960-1970.

Wuhrmann, von K., and H. Woker. 1948. Experimentelle untersuchungen uber die ammoniakund blausaurevergiftung. 1948. Schweizerische Zeitschrift fuer Hydrologie. 11:210-244. 

Bibliothèque nationale du Canada

33286506934427 